\title{
UNDERSTANDING URBAN LAND GOVERNANCE THROUGH "ACTION SPACE": IMPLICATIONS FOR ACCESS TO LAND FOR LOW-INCOME HOUSING IN MANAGING INFORMAL SETTLEMENTS
}





\title{
UNDERSTANDING URBAN LAND GOVERNANCE THROUGH "ACTION SPACE": IMPLICATIONS FOR ACCESS TO LAND FOR LOW-INCOME HOUSING IN MANAGING INFORMAL SETTLEMENTS
}

\author{
DISSERTATION
}

to obtain

the degree of doctor at the University of Twente, on the authority of the rector magnificus, prof.dr. T.T.M. Palstra,

on account of the decision of the Doctorate Board, to be publicly defended

on Wednesday $17^{\text {th }}$ April 2019 at 14:45 hrs

by

Reshma Shrestha

born on $11^{\text {th }}$ October 1978

in Kathmandu, Nepal 
This thesis has been approved by

Prof.mr.dr.ir. J.A. Zevenbergen, Supervisor

This research was conducted under the auspices of the Graduate School for Socio-Economic and Natural Sciences of the Environment (SENSE)

ITC dissertation number 349

ITC, P.O. Box 217, 7500 AE Enschede, The Netherlands

ISBN 978-90-365-4753-6

DOI $10.3990 / 1.9789036547536$

Cover designed by Job Duim Printed by ITC Printing Department

Copyright (c) 2019 by Reshma Shrestha

TC FACULTY OF GEO-INFORMATION SCIENCE AND EARTH OBSERVATION 
Graduation committee:

\section{Chairman/secretary}

Prof.dr.ir. A. Veldkamp University of Twente

\section{Supervisor}

Prof.mr.dr.ir. J.A. Zevenbergen

University of Twente

\section{Members}

Prof.dr. R.V. Sliuzas

Prof.dr.ir. C.H.J. Lemmen

Prof.dr. W.K. Korthals Altes

Prof.dr. S.R. Sharma

Dr. R.M. Bennett

University of Twente

University of Twente

Delft University of Technology

Kathmandu University

Swinburne University of

Technology 
Dedicated to Almighty Grod

“Om...." 


\section{Acknowledgments}

I would start by worshiping the Almighty God, for the spiritual strength that has to enable me to combat unforeseen hurdles throughout my doctoral journey and finally bringing this journey to the end.

This research is the result of direct and indirect contributions of many people, organizations to whom I am very grateful throughout this work period. Without their encouragement and help, I would not have reached this final stage

In particular, I wish to express my sincere gratitude to my Promotor/ supervisor, Prof. Jaap Zevenbergen, without whom I would not have been able to bring this work to completion. I am indebted for your scientific guidance and advice right from the beginning to end of this research. The support and encouragement that I got from you, especially, in those sagging periods due to my multiple health issues are priceless. After early retirement of my former daily supervisor (Dr. Arbind Man Tuladhar), the critical comments and suggestions you have given to sharpen my ideas, despite your very busy schedule, had eventually made possible to bring this research work in the present form.

I would like to extend my acknowledgment to other supervision teams who have contibuted in the part of this thesis, Prof. Dr. Mahesh Banskota, and Dr. Fahria Masum for providing me the invaluable scientific suggestions. Firstly, I am thankful to Dr. Tuladhar for supervising in the initial three years of my Ph.D. Secondly, I am thankful to Dr. Masum for supporting me in the final phase with a very sharp comment in strengthening the papers of the thesis and finalizing the thesis. Lastly, but not least, my acknowledgment goes to Prof. Dr. Banskota for valuable feedback during paper writings. The immense moral support that I received from you throughout my Ph.D. journey has always brought positive vibes. However, I feel very empty that you are not able to be in my Thesis Committee Board because of the unforeseen family consequences.

My gratitude extends to the NUFFIC for granting me with the financial support for four years and five months to carry out this research. Additionally, I am thankful to ITC scholarship for supporting me for an additional one year during my research. I would also like to acknowledge the Kathmandu University of Nepal for providing me intangible support by sufficient study leave.

This research could have not been done without the immense support from various officials from government organizations, private organizations, civil societies, and universities during my fieldwork in Nepal. I have encountered many helping hands and warm hospitability while conducting my fieldwork. Let 
me start my acknowledgment from officials who were from government organizations at the time of my research period: Mr. Ganesh Bhatta, Mr. Janak Raj Joshi, Mr. Suroj Rajkarnikar, Mr. Budhi Narayan Shrestha, Mr. Kishor Thapa, Mr. Susheel Dangol, Mr. Krishna Raj BC, officials from Ministry of Land Management, Cooperatives and Poverty Alleviation, Ministry of Urban Development, Ministry of Federal Affairs and General Administration. Secondly, my acknowledgment goes to officials from private sectors: Shreedaram Prajapati, Anish Joshi, Ramesh Basnet, officials from Civil Homes Pvt. Ltd., Brihat Investments Pvt. Ltd., CE Construction Pvt. Ltd., Astra Development Network Pvt. Ltd.Thirdly, my acknowledgment goes to civil societies groups: Lajana Manandhar, Hukum Bahadur, Dhana Lama and staff from informal settlers federations (SPOSH-Nepal, Nepal Mahila Ekta Samaj) and Lumanti Support Group For Shelter. I would like to extend my acknowledgment to Dr. Chudamani Joshi, Prof. Dr. Jiba Raj Pokharel, and Mr. Raja Ram Chhatkuli.

I wish to express my appreciation to the staff of ITC, particularly Loes Colenbrander for your efforts from beginning until thesis compilation and layout, Petra Weber for endless administrative support, Tony for your help in many aspects, Tina, Esther, Bettine, Theresa, Marie Chantal, Marion, Jacqueline, Saskia, Carla, Marga, Student Affairs, Financial Department, ICT department, ITC hotel, ITC library for assisting me in ITC in various ways. Further, I would like to express my gratitude towards all the staff of PGM department, Prof. Martin, Prof. Yola, Prof. Karin, Dr. Johannes, Dr. Divyani, Dr. Monica, Dr. Mafalda, Dr. Monika, Dr. Christine, Dr. Dimo, Dr. Mila, Dr. Luc, Dr. Javier, Liza, Frans, Mark and many more, who has been a part of my Ph.D. research indirectly. I am also thankful to all my colleagues Andres, Eva-Maria, Dr. Berhanu, Dr. Adish, Dr. Sara, Dr. Razie, Lydia, Rosa, Dr. Parinaz, Dr. Mitra, Alice.

Since my Ph.D. is conducted under the memorandum of understanding between PGM and School of Engineering, Kathmandu University, I have many well-wishers from Kathmandu University. In particular, my acknowledgment goes to Prof. Dr. Bhola Thapa, who is one of the key personal to motivate me to walk in this path. My sincere gratitude to Prof. Dr. Ramesh Maskey, Associate. Prof. Dr. Prachand Man Pradhan for a supportive hand from the initial phase of my Ph.D. I could not remain to acknowledge Prof. Dr. Damber Nepali, who has provided me motivational support to finish this Ph.D. Similarly, my sincere thanks go to my colleagues Mr. Uma Shanker Pandey, Mr. Nabaraj Shrestha, Mr. Subash Ghimire, Dr. Khagendra. In addition, I am thankful to Mrs. Joyti Pradhan for helping me to fulfill the administrative requirements. Finally yet importantly, I am very thankful to the Prof. Dr. Subodh Sharma (Registrar) and all the teaching staff as well as nonteaching staff of Kathmandu University. 
I also want to thank Enschede family, which is an important group of people, with whom I always got friendly support. My heartily thanks goes to Sujata Ghimire for taking care and concerned about me all the time. The feelings of very warm care that I got from you when I have coccyx fracture, is difficult to express in words. Similarly, my acknowledgment goes to adorable Arush, Dr. Chandra, Dr. Bhogendra, Dr. Shobha, Dr. Arun Pratihast Ayan, Sweta, Shrota, Arun, Bhuwan, Shakti, Sunil, Reshma, Sunita. Very special thanks go to Salina, Dr. Dhurba Pikha Shrestha, and his family, Gehini Joshi, Binod Shrestha. I should be thankful to Reena Pulles and her family for keeping happy ingredients in those monotonous periods.

Similarly, I also want to thank you to Nepalese friends, with whom I got unmeasurable support. I salute Sohan Khatri for facilitating me with proofreading of the final Thesis. I am thankful for indirect support for my beloved friends Preeti, Deepti, Sanju, and Deepa. My seniors Mr. Sunil, Dr. Purna. My sincere thanks go to my respected teachers Mrs. Pramila Singh, Mr. Rajendra Sharma, and all N.K Singh Memorial family for facilitating my daughter education during the period when I should stay in Nepal during my Ph.D. fieldwork.

Last but not Least, now I should start my acknowledgment to my close relatives, which of course is difficult to express in words. I bow down my head to all my close family members: Radha (Fupu) and her family, Rampyari (Fupu) and her family, Rambha (Thulma) and her family, Sanu (Thulma) and her family, Sunder (Mama) and his family, Kiran (Mama) and his family, Arjun (Mama) and his family, Jeevan (Mama) and his family, Samira Sthapit. Your blessings have always been my strength. My respect towards my in-laws: Dipu Shrestha, Sona Shrestha, Ruzul Shrestha, Ruzen Shrestha, Anju Shrestha, Mahika Shrestha. My heartily respect goes to my Mother-in-law (Savitri Shrestha), whose blessings, and support is a key factor in the Doctoral journey.

The special thanks go to Dr. Rehana Shrestha (Maiya, sister), who turned out to be my academic colleagues giving valuable scientific insight and also proofreading my papers. We spend almost five years together at Enschede sharing all those thrones that we face during our Ph.D. and consulting with each other to overcome it. I realize that both of us are turned to be each other's shadow. I deeply express my gratitude to my brother-in-law, Mr. Ragindra Man Rajbhandari to help me when I get stuck in a technical matter and also to boost me up to finish my Ph.D. My adorable thanks go to my brother, Rajan Shrestha, sister in law Prerana Shrestha and my sweet Niece Ashra Shrestha for supporting me by taking responsibility and care of our parents when both sisters are abroad. 
I am deeply indebted to my loving and caring husband Bipendra Shrestha for his endless support and for trusting me in every step that I have chosen to walk on and being so concerned for my career. Your inspirational phrase "Malai Thaha Cha Timile Garna Sakchauu" meaning "I know you can do it" is always ringing in my ear giving me confidence and my target to hold on the trust that you have shown on me. I have no words to express my feeling towards my pearl, my life, my love, Nani (my daughter Akshita Shrestha). "Mamu Kam Sakyo" meaning "Mom have you finished your work" has always pushed me to work on my Ph.D. Even being so young, you stood up with a potential to understand the reality and you cope with all those frustrating moments that I went through in this journey. I am very sorry as well for not being able to give enough time you deserve from me. Even being physically together, I was always mentally apart from you. I appreciate you for your effort to take care of me when I broke my hand and got coccyx fracture by always trying to be on my side to help me.

Finally, my warm greetings go to Daddy (Dhan Lal Shrestha) and Mummy (Radha Shrestha). Without your blessings, prayers, advice, and priceless support, I would not have been reached at this precious moment. I am indebted with your endless effort to create a comfort zone for me to work on my Ph.D. Thanking you all 


\section{Table of Contents}

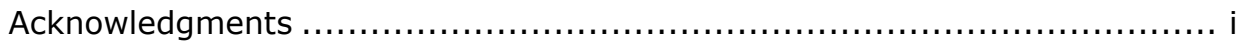

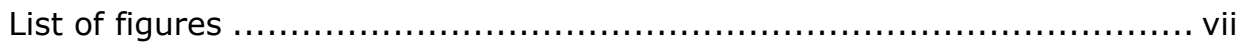

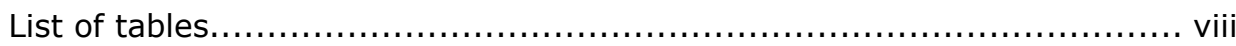

Chapter 1: Introduction and Background .....................................

1.1 Decades of struggling for physical space: Understanding the issue

and the context of the informal settlement....................................

1.2 Putting the governance in the context of urban land governance....4

1.3 Research Gaps in Urban Land Governance ............................

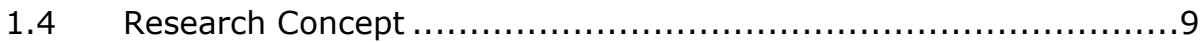

1.5 Research Objectives and Research Questions ...................... 11

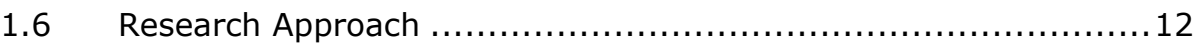

1.7 Selection of cases and its description ............................... 14

1.8 Thesis Outline ......................................................... 17

Chapter 2: Urban Land Governance: "Action Space", Legitimacy of and

Intervention Strategies for Urban Informal Settlements in Nepal ..............19

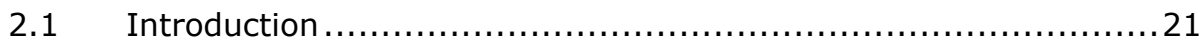

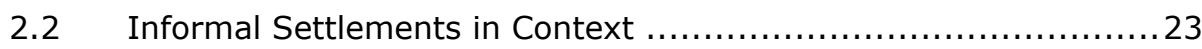

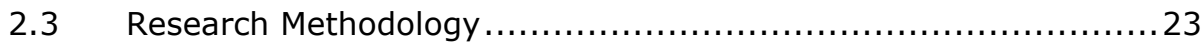

$2.4 \quad$ Urban Land Governance and Legitimacy .......................... 25

2.5 Interventions in Informal Settlements and Elements of Urban

Land Governance ........................................................ 29

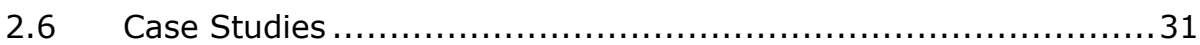

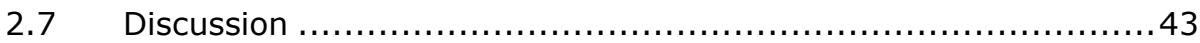

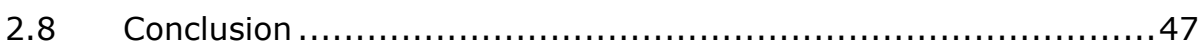

Chapter 3: "Action space" in Land Readjustment: Urban Land Governance,

Low-Income Housing Issues of Informal Settlers in Nepal.......................49

$3.1 \quad$ Introduction ........................................................... 51

3.2 Land Readjustment practice for allocating land for low-income housing ................................................................. 53

3.3 Conceptualizing action space in the LR to low-income plots .........55

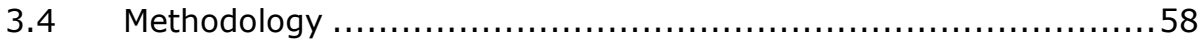

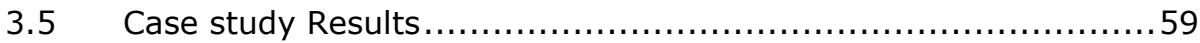

3.6 Discussion of the action space framework and legitimacy...........64

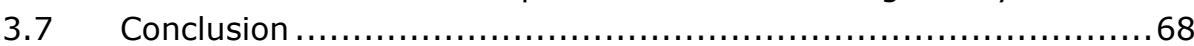

Chapter 4: "Action Space" Based Urban Land Governance Pattern:

Implication in Managing Informal Settlements from the Perspective of Low-

Income Housing ................................................................... 71

$4.1 \quad$ Introduction ............................................................ 73

4.2 Urban land governance and legitimacy in managing informal settlement ............................................................ 75

4.3 The concept of "action space" to analyze governance pattern ......76

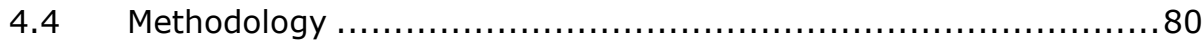




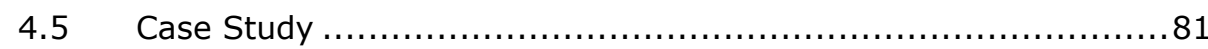

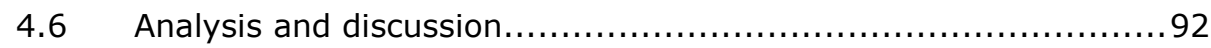

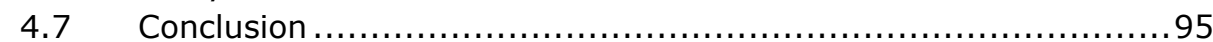

Chapter 5: Integrating the three key actors in the "Action Space" ............97

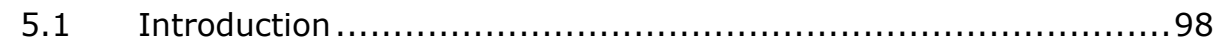

5.2 Main Findings from the research ................................ 99

5.3 The integrated framework of urban land governance based

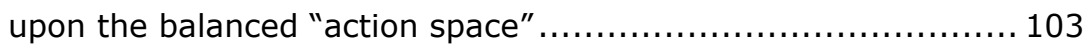

5.4 Towards balancing "action space" for managing informal settlements....................................................... 109

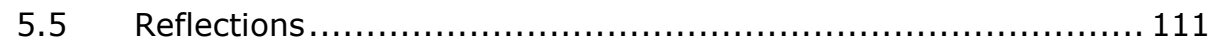

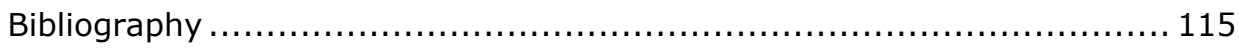

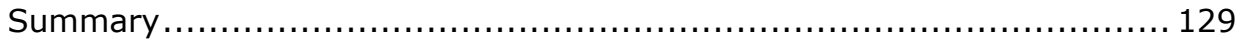

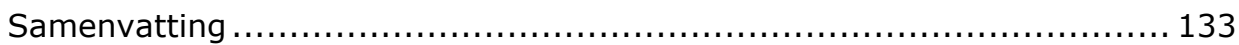




\section{List of figures}

Figure 1: Patterns of governance: "action space" for competing 'logics' in transition pathways

Figure 2: Conceptual framework of "Action Space" to understand urban land

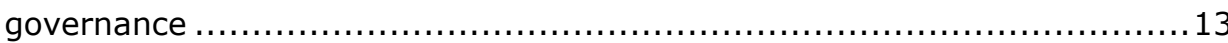

Figure 3: Location of selected cases ........................................... 16

Figure 4: Location Map of selected cases based on the seven provinces......16

Figure 5: Schematic representation of chapters' linkage........................17

Figure 6: Analytical framework of "Action Space" to analyse governance pattern between government and civil society actors ...........................26

Figure 7: Analytical framework of "Action Space" to analyse interaction between government and market actors..........................................5 54

Figure 8: Location Map of Land Readjustment Projects in the Kathmandu Valley (Including Location of Icchangu LR project) .............................6 60

Figure 9: Location of low-income housing in the Icchangu LR project. ........61

Figure 10: Analytical concept of "Action Space" .................................77

Figure 11: Analytical framework of "Action Space" to analyse governance pattern between market and civil society actors.................................79

Figure 12: Location Map of relocated informal settlements (squatter settlement) and Kirtipur housing project (KHP) ............................... 82

Figure 13: Residents' view on the involvement in the KHP Project. ............86

Figure 14: Residents' view on the accessibility to income generating

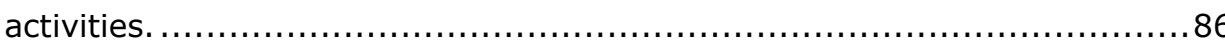

Figure 15: Residents' perception on land use for economic improvement. ...87 Figure 16: Common open space used for social entrepreneurship by an

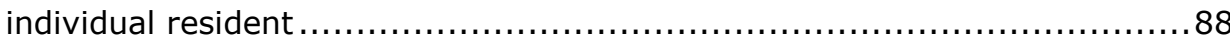

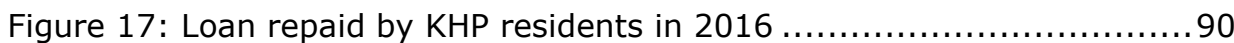

Figure 18: Residents' perception on social aspect.............................91

Figure 19: Government actors influence in the interaction between market

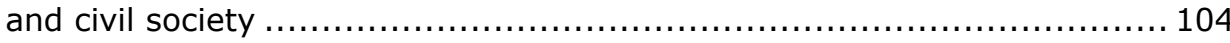

Figure 20: Civil Society actors influence in the interaction between government and market actors ............................................... 105 Figure 21: Market actors' influence in the interaction between Government and Civil Society actors ...................................................... 106 Figure 22: Integrated Framework of "action space" for understanding urban land governance ................................................................ 108 


\section{List of tables}

Table 1: Elements and Indicators of good urban land governance intervention strategies.................................................................. 31

Table 2: Empirical data of "Srinagarka" informal settlement in security tenure

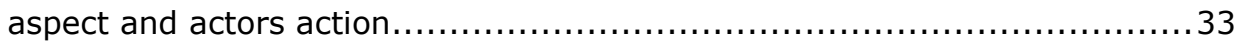

Table 3 : Empirical data in "Srinagarka" in land development aspect and

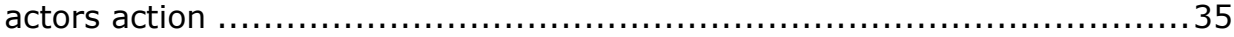

Table 4: "Bansighat" settlers' views in urban land governance indicators ....36

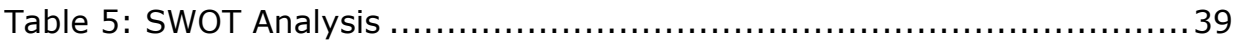

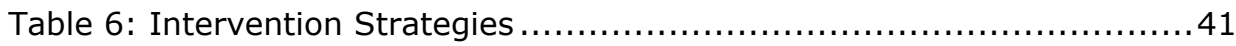

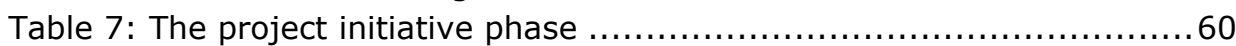

Table 8: Analytical framework of Social Entrepreneur. ........................ 78

Table 9: Analytical framework of corporate social responsibility............... 80

Table 10: overviews of activities and actors involved in KHP $\ldots \ldots \ldots \ldots \ldots \ldots \ldots . \ldots 3$

Table 11: Actors involved in the selected cases........................... 107

Table 12: Balancing Notion/factors of third actors on each arm of the "action

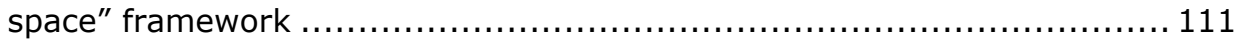




\section{Chapter 1: Introduction and Background ${ }^{1}$}

\footnotetext{
${ }^{1}$ The chapter is based in part (section $1.1,1.4$ ) on the following conference publication.

Shrestha, R., Tuladhar, A., Zevenbergen, J., \& Banskota, M. (2014). Decades of Struggle for Space: about the legitimacy of an informal settlement in urban areas. Paper presented at the Engaging the challenges, enhancing the relevance: XXV FIG Congress, June $16^{\text {th }}-21^{\text {st }}$, Kuala Lumper, Malaysia.
} 


\subsection{Decades of struggling for physical space: Understanding the issue and the context of the informal settlement}

\section{An Informal settlement in context}

Informal settlement is a worldwide issue that has existed in the global South for more than one decade (Srinivas 2005; Davy and Pellissery 2013). Different terminologies are used to describe informal settlement, particularly in developing countries. Such terminologies are slum, shantytown, squatter settlement, illegal housing, bosti (India), favela (Brazil), gecekondu (Turkey).

In Nepal, informal settlement is termed as "Sukumbashi Basti", which means the settlement formed due to the illegal encroachment of land and has no official land ownership certificates. However, "Sukumbasi" ('informal settlers') does not address the person who has land elsewhere in the rural area even though, the land is not technically feasible for sustaining a livelihood.

Besides "Sukumbasi", there are also some settlers who refer to themselves as "Swabasi", a term literally meaning "dwellers staying by themselves" (Moffat \& Finnis, 2005). Although these settlers also lack legal documents of their existence, they do not refer to themselves as "Sukumbasi" (Tanaka 2009). Owing to these ambiguities of the term, the study conducted by UN-Habitat (2013), has defined informal settlement, as "settlement on government, public or private land by the urban poor without lawful authority" and slum as "settlement on the unhygienic, unsecured and vulnerable place having no minimum urban infrastructure".

Therefore, the term "informal settlement" used in this study refers to the settlement without formal land tenure.

The key factor in the emergence of informal settlement is urbanization. Urbanization, however, is an important social and economic phenomenon, which is taking place rapidly all around the world (Deng et al., 2009). The driving factors of urbanization are population growth and rural-urban migration. Indeed, these internal migrations are always accompanied by "push factors" of rural areas (unemployment, low standards of housing and infrastructure, lack of educational facilities, conflict, surplus labour) and "pull factors" of urban areas (economic opportunities, attractive jobs, better education, modern lifestyle)(Kötter \& Friesecke, 2009). Nevertheless, these migrants often encounter great difficulties in accessing land to fulfill the shelter needs, as land and housing markets are usually too expensive and take lengthy processes. Therefore, they are not able to enter into the formal land and housing market. This results in the illegal occupancy of vacant land, often 
publicly owned land, where there is less fear of being dislodged than from private property (Aiken 1981).

The issues encountered in informal settlements are multidimensional, covering socio-economic, physical, and legal characteristics. The socio-economic characteristics of informal settlement relate to lack of accessible health services, low literacy rate, and a high unemployment rate; physical characteristic refers to a lack of public services such as water supply, electricity, and drainage; legal characteristic refers to the lack of legal rights for occupied land (Fernandes, 2011; Srinivas, 2005; Wekesa et al., 2011). Among these three characteristics, lack of legal recognition due to absence of a legal document of occupied land is a dominant characteristic that results in the settlement as being considered as informal.

In short, the issue of informal settlement manifested into endogenous factors and exogenous factors. The endogenous factors are the inherent attribute of informal settlement like financial resources, human skill whereas, the exogenous factors are lack of land and housing policies, legal norms and process to accommodate the low-income groups within the urban area (Srinivas 2005). This study mainly focuses on exogenous factors.

\section{Access to land for low-income housing: An issue related to the informal settlement}

Globally, the provision of low-income housing has become a huge challenge for national authorities in most of the developing countries (Addo, 2014). Lowincome housing is a reasonable quality housing that is affordable to people of low-income groups. Though in many developing countries, the government has introduced various programs and policies to allocate low-income housing, there is still a failure in meeting the low-income housing demand. This is an impact of the continuous growth in the numbers of people migrating to cities and needing a place to live in (Sivam \& Karuppannan, 2002).

The influencing factors in the rate of low-income housing supply vary from technical, legal to institutional issues. Beside these factors, the major constraint in the development of low-income housing is linked to the access to land below the formal market price (Huang, 2012; Mittal \& Swamy, 2014). In urban areas, land price is generally higher than the housing price. Apart from high land price, Addo (2014) shows in the case of Abuja and Brazil that difficulties in acquiring land can also impact the supply of low-income housing. Similarly, Mittal et al. (2014) shows that, in the study conducted in Gujrat, India, although private sectors are willing to develop low-income housing, they are demotivated due to the difficulty in accessing land at the marginal price. Additionally, housing-related studies conducted in various countries 
(Sengupta, 2006; Sivam et al., 2002) indicate that weakness in government policies to include the strength of private and civil society sector in the process of delivery of low-income housing is another major setback in fulfilling the housing needs of low-income groups. As a result, informal settlements are in an increasing trend.

Therefore, this research focusses on access to land for developing low-income housing in order to address the issue of informal settlement.

\subsection{Putting the governance in the context of urban land governance}

According to Mayntz (2003), the concept of governance emerged after World War II, when the government aimed to steer the nation's social and economic development in the direction of predefined goals. The approach, adopted to achieve these goals, was the top-down approach- with the policy development by government and the policy implementation by public agencies. The limited success of this approach, however, has led the theory to extend to the bottomup approach, that takes into consideration the policy formulation and implementation in a participatory way. Later the theory extended to policy development and implementation in public/private networks and selfregulating societal systems which are termed as "shifting patterns of responsibility" in the style of governing (Rhodes, 1996; Stoker, 1998).

The "shifting patterns of responsibility" between the government and private sectors leads to a blurring of boundaries between them (Stoker, 1998). Even though there is a blurring of boundaries, the government actors have to depend on public actors to achieve the goal set by the government. This is because private actors, civil society, and citizens have important resources as well as the power to obstruct policy interventions. This implies that the integrated action of these actors is required to resolve societal problems such as informal settlements (Klijn, 2008).

The integrated action within networks of key actors (government, market, and civil society) is basically defined by the policies and processes that determine which actors to involve and who have power in decision making (Graham et al., 2003). However, within the network of these three key actors, the action of each actor has been observed to emerge from the power that exists inside and outside the formal authority and institutions of government (Jiboye, 2011).

In addition, Bates (2012) demonstrates the importance of cross-sectorial governance to tackle the societal issue in a study of sustainable urban water management. The study has shown success in obtaining sustainable urban water management by integrating water governance i.e. actors' action in water 
management planning with urban governance i.e. actors' action in urban land use planning.

In conclusion, in this research, governance is defined as an integrated action that exists in the network of three key actors-government, market, and civil society. Moreover, this research considers cross-sectorial governance by integrating urban governance issues with respect to managing informal settlements with land governance in accessing the land for low-income housing.

The following sections describe the initiatives by various international organizations in urban governance and land governance in general followed by, the identification of the gaps in urban land governance in particular.

\section{Global Urban Governance initiatives}

According to Baud and Hordijk (2009), urban governance is about the process of regulating urban area for sustainable development. Urban governance includes both formal and informal arrangements through which the diverse interests of various actors are accommodated. This is done by creating space for ideas and participation of various actors in securing necessity components of urban life such as adequate shelter, security of tenure, safe water, sanitation, health, education, employment, public safety and mobility (UNHABITAT, 2002).

Several multilateral and bilateral organizations such as UN-Habitat, UNDP, Slum Dwellers International, Asian Coalition for Housing Rights (ACHR), and research institutes have taken initiatives towards addressing urban governance challenges like urban poverty. For instance, UN-HABITAT has conducted the two international initiatives, namely, Global Campaign for secure tenure (GCST) and Global Campaign on urban governance (GCUG). The objective of the GCST was to improve the condition of people living in informal settlements by adopting approaches like promoting the security of their residential tenure by regularising and providing affordable shelter policies. In a similar way, the objective of GCUG was to eradicate urban poverty by developing inclusiveness in the city. Inclusiveness refers to a place where everyone, regardless of wealth, gender, age, race or religion is enabled to participate productively and positively (Global Shelter Cluster, 2009; Mitlin \& Satterthwaite, 2012; UNHABITAT, 2002)

In addition to the urban governance initiatives to promote a participatory approach, there are few initiatives in developing a framework for assessing urban governance. Under the umbrella of GCUG, Urban Governance Index (UGI) and tools to support transparency in local governance were developed. The UGI aims to catalyze local action to improve the quality of urban 
governance and measures the improvement in the quality of local governance (Moretto, 2015; Wilde, 2011). Improving quality in local governance can contribute to inclusive cities and ultimately contribute in poverty reduction. Similarly, transparency toolkits consist of five different tools, supporting the assessment of transparency in local governance (Transparency Interntional, 2004). The part of these toolkits has been applied by Shrestha (2009) in accessing transparency in land accquisition for infrastructure development.

Another initiative that is reported in urban governance is a communitystrengthening program such as Asian Coalition for Community Action (ACCA) supported by the Asian Coalition for Housing Rights (ACHR). The aim of such initiative is to strengthen the community for implementing community-based housing plan in coordination with local government. As such, the program catalyzed and supported the community level initiatives and facilitated in building partnerships between community organizations and the government (Boonyabancha \& Mitlin, 2012). Similarly, the initiative of Homeless International such as CLIFF (Community-Led Infrastructure Finance Facility) acted as a catalyst in the upgrading of informal settlements through financial support for community-initiated housing and infrastructure projects (Jack \& Morris, 2005; Mitlin, 2007).

\section{Global Land Governance initiatives}

Land governance is about determining and implementing sustainable land policies and establishing a strong relationship between people and land (Enemark et al., 2009). It is about rules, process, and structure through which decisions are made on the access to land, land use and land development. It is also about implementing the policies by reconciling the conflicting interest of different groups of actors (Deininger, Augustinus et al. 2010). Further land governance is related to power on access to and use of land (Deininger et al., 2010b; Palmer et al., 2009).

Likewise, several multilateral and bilateral organizations such as World Bank, GLTN, FAO and research institutes have taken the initiatives towards land governance. One of the most important initiatives taken in land governance by World Bank is the Land Governance Assessment Framework (LGAF). It is a diagnostic tool to assess land governance in terms of legal framework, policies, and practices of particular countries (Deininger et al., 2012). Similarly, in order to improve governance of land tenure, FAO has developed voluntary guidelines of tenure of land, fisheries, and forests. The guideline includes governance in housing security of informal settlement and land development approaches like land readjustment (Seufert, 2013). Taking a land management perspective, Koroso et al. (2013) have developed a framework to assess the governance of a market in land use rights. The framework is based upon five principles of 
good governance, which are equity, participation \& access to information, efficiency \& effectiveness, transparency and combating corruption.

Apart from guidelines and framework, there are initiatives in developing indicators for evaluating land governance by measuring performance in the domain of land administration (Arko-Adjei et al., 2011). Some of the examples are FAO's indicators on good governance in land tenure and administration (FAO, 2007), and the World Bank and FAO's indicators of the success of land administration reform (Burns, 2007).

Besides indicators, the academic institutions have developed conceptual models for measuring the end-to-end performance of land administration. The rationale for developing this model is that fragmentation of business processes in land administration across several autonomous organizations generally impairs end-to-end business process flow, service delivery in the land sector (Chimhamhiwa et al., 2009) and relevancy in combating land issues related to informal settlements. Additionally, there is a great contribution in the sector of land administration by developing the land administration domain model (LADM), recognized as ISO standard 19152:2012 globally (Lemmen et al., 2009; Lemmen et al., 2015). Similarly, by developing social tenure domain model (STDM) which supports the development of land information system where legal recognition of occupied land do not exist (Augustinus et al., 2006). Moreover, Hendriks et al. (2019) have recently modified a pro-poor land recordation model initially developed by Zevenbergen et al. (2013) that supports in tackling land rights issue of informal settlers and access to land for poor. The impact on the informal settlers caused by weak land governance in post-disaster period has shown (Shrestha et al., 2015b). To strengthen land governance during disaster risk management Unger et al. (2019) have developed LA-DRM model, which supports land administration in preparedness, mitigation and recovery stages.

Finally, the initiative in urban land governance to regulate the urban land market by Urban Landmark is also a remarkable one. It focuses on the African context of access to land for low-income groups by improving the land governance at municipal level (Mark, 2012). Similarly, Alemie (2015) has developed the conceptual model to understand a continuum of urban land governance.

Although there are various initiatives such as awareness raising, an assessment framework, monitoring indices, toolkits, and conceptual models to improve urban governance and land governance, the issues of informal settlement still remains as a global issue. The subsequent section discusses the research gaps in urban land governance. 


\subsection{Research Gaps in Urban Land Governance}

This section elaborates on research gaps at two levels; Societal and Conceptual.

Considering the societal context of informal settlements as discussed in section 1.1 , the housing issue is the most important one. Among the various factors that influence the development of low-income housing, availability of suitable land for developing housing at low-price is an important factor. However, the literature review on urban and land governance shows limited research and initiatives that focus particularly on access to and allocation of land for developing low-income housing. The existing initiatives taken by various international organizations and academic institutions (discussed in section 1.2) reveal that apart from initiatives in developing the assessment framework, indicators, and the conceptual model for pro-poor land recordation, there are only few initiatives in urban land governance that focus on managing informal settlements. Most of these initiatives, however, focus on in-situ upgrading by providing basic services such as water, sanitation, road access, rather than resettlement of these informal settlers. Resettlement is important since most of the informal settlements reside in vulnerable areas. In addition, these initiatives seem to have taken up to the project level only, and not integrated at the policy level. Although there are initiatives towards low-income housing, the integrated approach of low-income housing by access to and allocation of land for low-income housing, is lacking. In this regard, one of the research gaps seen is how to manage informal settlements in a suitable manner, by adopting a proactive approach in providing access to and allocation of land for low-income housing.

The general theory of governance suggests the necessity of reconciling the conflicting interests and balancing the logic of three actors (government, market and civil-society), by integrating three perspectives, (legal, market and social) respectively. Similarly, in the context of managing informal settlement, the theory suggests the necessity of creating a governance network by linking these three actors. Nonetheless, only involving various stakeholders in the design and implementation of public policies does not necessarily reveal the cooperation among stakeholders, unless, there is some managerial effort to reconcile both horizontal and vertical level of joint action among the actors in the governance network (Klijn, 2008). This calls for a conceptual framework/ mechanism on balancing the logic and actions of these three actors. However, there is only limited research that attempts to explore the interaction between these actors in urban land governance, for providing access to and allocation of land for low-income housing. In this respect, another research gap identified conceptually from governance perspective is about bringing together the 
government, market and civil society actors by reconciling the conflicting actions and logic.

\subsection{Research Concept}

The concept of "action space" is adopted in this research because it conceptualizes the interaction and dynamism among the three governance actors, including their competing 'logics' and actions. In doing so, the concept aids in understanding the urban land governance in managing informal settlements, thereby supporting in narrowing the conceptual and societal gaps identified in section 1.3.

"Action space" is also termed as "room for maneuver" (Harpham \& Boateng, 1997). The term "action space" is understood differently in different domains such as a means of production (i.e. land and real estate), an object of consumption, and a geographical site of social action. Moving beyond space as container ontology, Gotham (2003) conceptualizes space as a social construction that shapes social action and guides behavior. In this research, "action space" is conceptualized as the space for conducting the actions as per each governance actor's own logic. The different actors in the governance have a different underlying logic that frames their view of the world. These actors also seek to enroll other actors into their logic. As a result, the dominant type of actors i.e. the most effective enroller defines the dominant form of governance pattern in that period of action (Foxon et al., 2009).

A number of authors in the various fields of applications has applied "action space" in different context. For instance, Dijst (1999) has applied the concept in spatial planning in order to capture the social behavior of actors; Safier (2003) has adopted the concept to develop the participatory model, which consists of four dimensions: organizational, technical, social \& strategic. Safier (2003) applied the concept as an analytical lens to determine the degree of freedom of two actors (government and civil society) in four dimensions such that they can play their role in order to achieve a sustainable urban area.

Besides the above-mentioned application of the "action space", Foxon (2013) applied the concept to study the governance pattern among the three key groups of actors (government, market, and civil society) and the ways these actors influence the transition pathways from high-carbon to low-carbon regime. The concept is instrumental to analyze the three types of dominant form of governance pattern, - government-led, market-led, and civil societyled; and to explore the dynamism of various actors' action and their logic. The set relations, to analyse the interaction between two actors in each arm (see Figure 1), provides potential to analyse dynamism ('push' and 'pull') of action space. 
The six different types of the relation between the three actors are shown in the conceptual framework developed by (Foxon et al., 2009). The relations are in both directions between government and market; between market and civil society; and between civil society and government (see Figure 1). The interaction between government and civil society actors depict two different forms of relations. These relations are "political acceptability", which emerges when government actors are dominant actors and "political legitimacy", which emerges when civil society deemed to have power. Similarly, two types of relations emerges in the interaction between government and market actors. These relations are "regulatory compliance", emerges when government actors are dominant actors and "level playing field" emerges when market actors deemed to have power. Finally, the interaction between market and civil society actors reveals two different forms of relations. If civil society actors deemed to have power, "citizen entrepreneurs" emerges and "compliant consumers" emerges when the market is deemed to have power (Foxon et al., 2009).

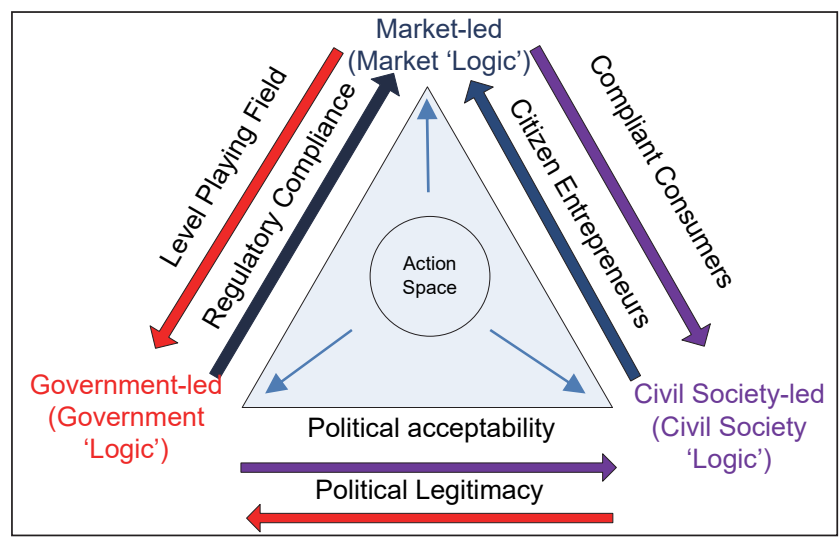

Figure 1: Patterns of governance: "action space" for competing 'logics' in transition pathways. Source:(Foxon, 2013; Foxon et al., 2009)

This research adopted the "action space" concept of (Foxon, 2013; Foxon et al., 2009) as an analytical framework. The relations defined between two actors in the concept by Foxon et al. (2009) are conceptualized as per the context of this research, which is further modified accordingly, developing a context-specific integrated conceptual framework of "action space" for understanding the urban land governance. However, the theory underlying in this concept remains the same. 


\subsection{Research Objectives and Research Questions}

Main Objective:

To understand "action space" based urban land governance by integrating actions and logics of all three key actors (government, market, and civil society) in managing of informal settlements

Sub Objectives:

To understand the "action space" based urban land governance patterns between government and civil society actors by developing a theoretical framework in the case of urban informal settlements and study intervention strategies for managing informal settlements.

1. How can the concept of "action space" be used to develop a theoretical framework for understanding the governance patterns between government and civil society for managing informal settlements?

2. What are the intervention strategies for managing informal settlements?

To understand the "action space" based urban land governance patterns between government and market actors by developing a theoretical framework in allocating land for low-income housing in the case of Land Readjustment

1. How can the concept of "action space" be used to develop a theoretical framework for understanding the governance patterns between government and market actors in allocating land for low-income housing?

2. How to incorporate market actors in the allocation of land for low-income housing?

To understand the "action space" based urban land governance patterns between civil society and market actors by developing a theoretical framework in managing informal settlements and low-income housing in the case of resettlement of informal settlers

1. How can the concept of "action space" be used to develop a theoretical framework for understanding the governance patterns between civil society and market actors in managing informal settlements and lowincome housing?

2. How can social and market dimensions be conceptualize considering scale and level? 


\subsection{Research Approach}

The research approach is a guideline to fulfil research objectives. There are many research approaches as case study approach (Yin, 2003), mixed design approach (Johnson \& Onwuegbuzie, 2004), system thinking approach (Checkland, 2000), qualitative approach (Silverman, 2010), and quantitative approach (Kumar, 2000). This research proposes to adopt a system thinking as an overarching research approach. Under the framework of this research approach, different interrelated methods and techniques are applied to achieve the various objectives, as no single method is mutually exclusive and can cover all the objectives (Avison \& Fitzgerald, 2003; Yin, 1994).

The way of understanding the system by examining the linkages and interaction between the subsystems and actors that compose the entirety of the system is known as systems thinking (Checkland, 2000).It is a problemsolving process by viewing a problem as parts of an overall system (Kaufman, 1968). It is an organized, purposeful structure that consists of various interrelated and interdependent entities which interact with each other (Andrew \& Petkov, 2003). Many natural processes are analyzed based on system thinking like the environmental system and ecological system. Besides these natural systems, human-made processes like governance consisting of institutions, policies, actors, networks, is also analyzed from system thinking (Duit et al., 2010). Bosch et al. (2007) advocate that system thinking can be applied to explore and analyze a complex problem of sustainable land management. This approach has also been used in the study of land registration processes (Zevenbergen, 2002) and parcel based geo-information systems (Tuladhar, 2004).

Under the framework of this research approach, different interrelated methods and techniques are applied to achieve the various objectives, as no single method is mutually exclusive and can cover all the objectives (Avison et al., 2003; Yin, 1994).

Figure 2 shows the conceptual framework of this research in which the systems thinking approach is adopted. Land governance and urban governance are two subsystems in the urban land governance system. The interactions between the three key actors (government, market, and civil society) that exist in both the subsystems are analyzed by applying the concept of "action space". 


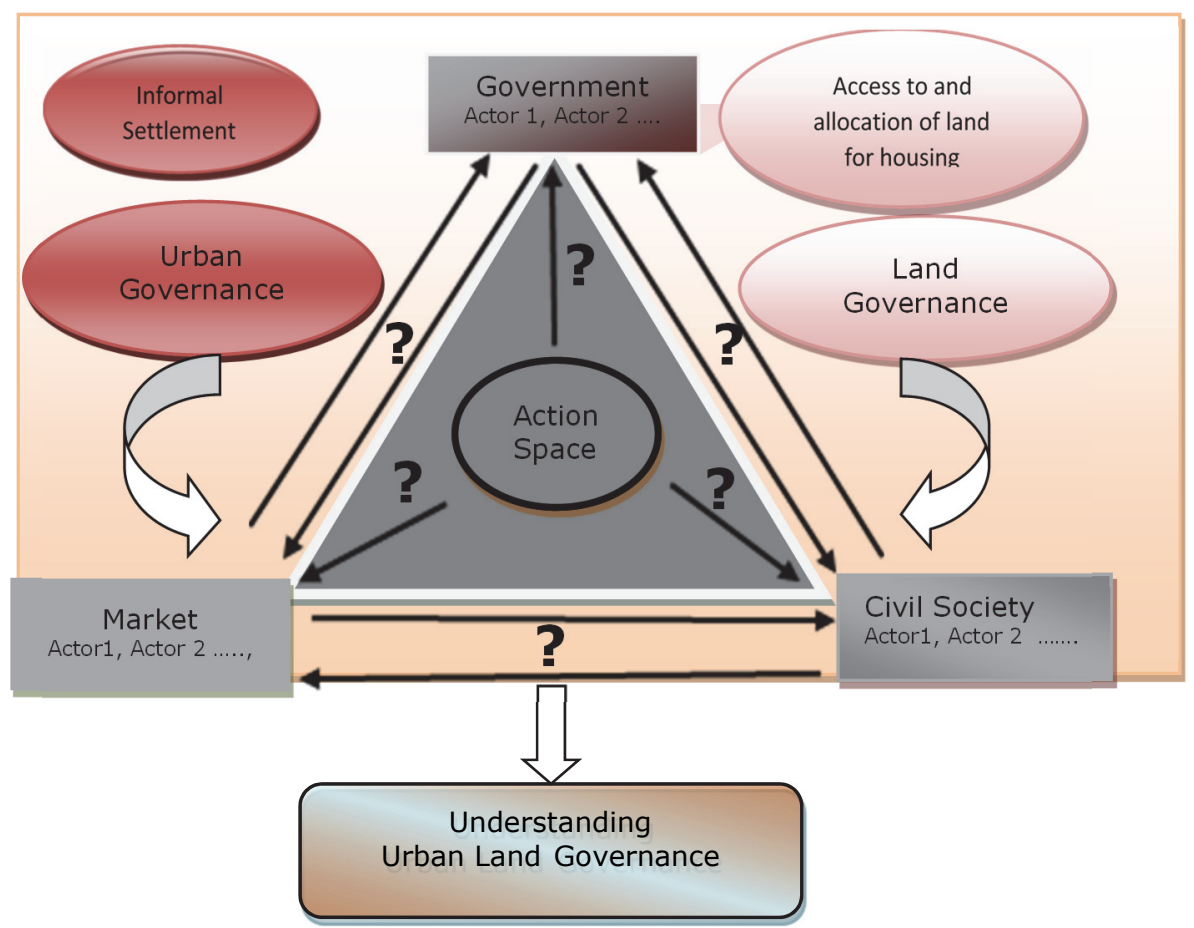

Figure 2: Conceptual framework of "Action Space" to understand urban land governance

Within the system thinking approach, the case study approach is applied in order to understand the interaction between each two sets of actors in urban land governance. Each arm of the framework is conceptualized in the following chapters of this thesis in order to obtain a complete picture of urban land governance in managing the urban issue of informal settlements and the land issue of allocating land for low-income housing.

Case study design can be formulated as a single-case or as multiple-case design. Although both single and multiple case studies are relevant and lead to a successful case study, Yin (2003) suggests on making a choice for multiple cases. According to the author (Yin, 2003), analytic conclusions derived from multiple case studies are more powerful than those derived from a single case study. Similarly, the multiple case study approach has been one of the significant research approaches in the aspect of governance (Stewart, 2012).

The sampling of cases can be based on extreme cases, typical cases, maximum variance, minimum variance, critical cases (Zevenbergen, 2002). Stewart (2012) suggests that the selection of multiple cases with maximum variance on the dependent variable is an excellent way of avoiding bias. The investigation of key factors by bringing a number of contrasting cases is considered as the strength of multiple case approaches. Therefore, this study 
follows the maximum variance case study selection strategy. The steps for conducting multiple case studies are designing data collection protocol, conducting a case study, individual output, and cross-case analysis (Yin, 2003).

\subsection{Selection of cases and its description}

The three cases are selected in this research following the maximum variance sampling strategy (Seawright \& Gerring, 2008). The selected cases are; 1) regularisation of informal settlement, 2) land readjustment for providing land for low-income housing, and 3) resettlement of informal settlers by providing low-income housing. Brief descriptions of the selected cases are as follow:

\section{Regularisation of informal settlement}

Regularisation of informal settlements entails providing security of tenure such that poor and marginalized people, who are living informally by occupying public or private land, are not evicted without alternative arrangement (Durand-Lasserve, 1999). However, it is not always feasible to adopt in-situ regularising by upgrading the settlement in the existing location when the settlement resides in the vulnerable area such as the bank of a river. Hence, in some situations, the resettlement of the informal settlers is an alternative intervention.

This case is selected in this research to analyze and understand the government-civil society led governance pattern. In the governance, regularisation of informal settlements refers to providing legal recognition (Durand-Lasserve \& Royston, 2002) in which the interaction between government actors and civil society actors is on central focus.

For this research, two cases of informal settlements; one in the central region, and one in the eastern region ${ }^{2}$ of Nepal are selected (see section 2.1.1 in Chapter 2 for detail).

\section{Land readjustment for providing land for low-income housing}

Needham (2007) has given a broad overview of land readjustment as "In a particular area, the boundaries of the rights to land ownership or land use may impede the desired use of the area as a whole [..]. To realize the desired aims, the structure of landholdings (both ownership and use rights) must be changed. This change is called Land Readjustment". The vested technical

2 On $20^{\text {th }}$ September 2015 , Nepal was divided into seven provinces. In this regard, one case which was in the mid-region lies in province 3 and the other case which was in the far-western lies in province 2. 
problems in this method are large upfront expenditures, tricky valuations of contributed interest, determinations of cost equivalent land and length of time (Sagalyn, 2009).

The case of Land Readjustment (LR) is selected with two fold objectives. Firstly, the LR process consists of role of various actors like local government, an association of land owners, private developers (Turk, 2008). Therefore, LR is a suitable case to analyse and to understand the government-market led governance pattern. Secondly, LR is considered as a land development approach, having potential to supply land for low-income housing (Turk, 2008). This makes a suitable case in order to analyse provision of low-income housing for managing of informal settlements.

3. Resettlement of informal settlers by providing low-income housing

Resettlement is one of the approaches of managing informal settlements in which informal settlers' are provided formal housing in another location. According to Evrard and Goudineau (2004), resettlement induces displacement and mobility if the social, economic and cultural consequences that arise after resettlement are not sufficiently addressed. Therefore, shifting the settlers' into another location requires the involvement of the affected settlers' themselves in planning and designing until the implementation stage of the resettlement project (Patel et al., 2002).

The case of resettlement of informal settlers by providing low-income housing is selected to analyze and understand the market-civil society led governance pattern. The Kirtipur Housing Project (KHP), the resettlement project for informal settlers' executed in central region (province 3 ) is studied in this regards. The focus of this case is on the access to land for developing lowincome housing. The location of the case is shown in Figure 3 and the detail of the case is described in Chapter 3 (section 5). 


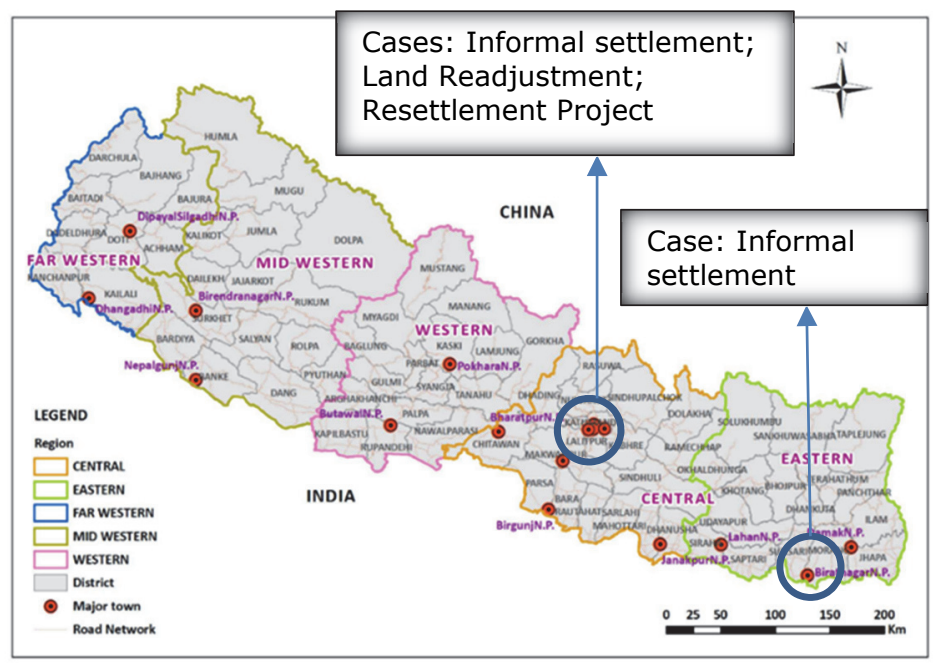

Figure 3: Location of selected cases $^{3}$

Source: Department of Survey, Nepal

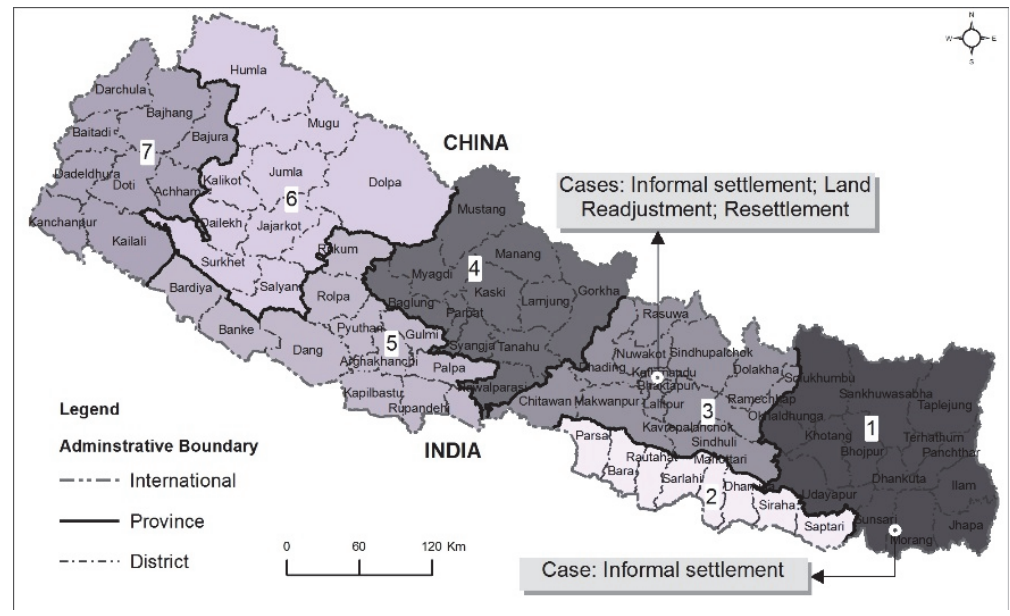

Figure 4: Location Map of selected cases based on the seven provinces Source: Department of Survey, Nepal

3 The seven provinces formed by grouping the existing districts. The current system of seven provinces replaced an earlier system where Nepal was divided into fourteen Administrative Zones that were grouped into five Development Regions. 


\subsection{Thesis Outline}

This thesis consists of five chapters (see Figure 5).

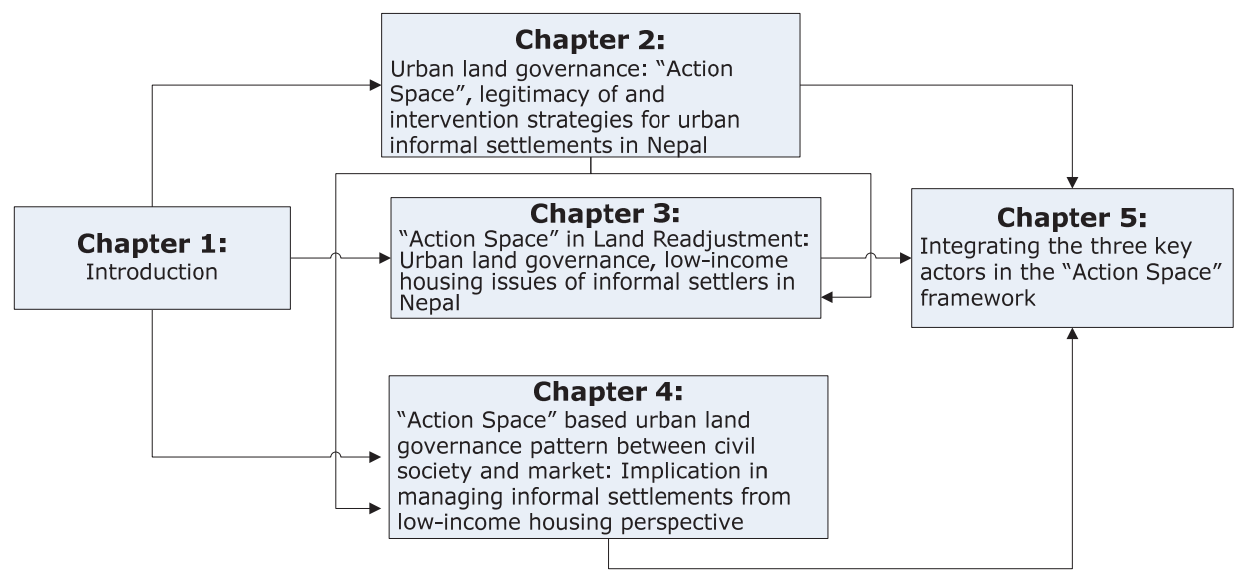

Figure 5: Schematic representation of chapters' linkage

Chapter One- It is the introduction and background of the research including the conceptual description, objectives and overarching methodology of the research.

Chapter Two - This chapter is devoted to understanding the governance pattern between government and civil society actors. The modified "action space" concept underpinning this chapter provides the analytical tool to understand the government-civil society led governance pattern. This chapter presents the findings from the detailed investigation of exploratory and explanatory case studies of informal settlements from the regularising perspective. In addition, the intervention strategies identified in this chapter show the requirement analysis in managing the informal settlements. Further, it links to the next chapters by recommending the need to tackle low-income housing issues in managing informal settlement.

Chapter Three - This Chapter focuses on the understanding of the governance pattern between government and market actors. The modified "action space" concept underpinning this chapter provides the analytical tool to understand the government-market led governance pattern. The chapter presents the findings based on the exploratory and explanatory case study of land readjustment in which the unit of analysis is land for low-income housing. This chapter links with the former chapter by introducing the market actors and addressing the issue of informal settlement from a housing perspective. 
Chapter Four- Chapter Four focuses on the understanding of the governance pattern between the market-civil society actors. This chapter has conceptualized the "action space" framework to understand the interaction between the market and civil society actors in the provision of low-income housing. The chapter presents the findings, which is based on the explanatory case of resettlement of informal settlements by providing low-income housing. This chapter has a linkage with chapter two because in chapter two (section 2.7) the resettlement of informal settlers has been prescribed intervention strategy for managing of informal settlement.

Chapter Five - This Chapter synthesizes the findings of the entire research and discusses their implications in urban land governance for allocating land for low-income housing from both conceptual and societal perspective. The findings are structured by addressing each research objectives and respective research questions.Furthermore, this Chapter provides recommendations on future research directions. 


\section{Chapter 2: Urban Land Governance: "Action Space", Legitimacy of and Intervention Strategies for Urban Informal Settlements in $\mathrm{Nepal}^{4}$}

4 This chapter is based on the published paper in the peer reviewed journal: Shrestha, R., Tuladhar, A. M., Zevenbergen, J. A., \& Banskota, M. (2016). Urban Land Governance: "Action Space", Legitimacy of and Intervention Strategies for Urban Informal Settlements in Nepal. Nordic Journal of Surveying and Real Estate Research, $11(2), 20-50$. 


\begin{abstract}
At the global level, the informal settlements are in a dichotomy of legal and illegal debates. This paper analyzes the issue of informal settlements from the legitimacy perspective. It reveals that, although the settlements are not in legal legitimacy, there is tendency of social legitimacy. The challenges of urban land governance are in how to minimize the gap between legal legitimacy and social legitimacy. Firstly, this paper explores on how the actions of government and non-government organizations contribute towards legitimacy. To achieve this aim, the analytical framework of "action space" is applied. Secondly, it focuses on identifying intervention strategies that narrow the gap between legal legitimacy and social legitimacy. We studied two cases of informal settlements: the first is to explore the gap and the second is to explain the intervention strategies. The results show, that due to lack of "action space" of government actors towards legal legitimacy, the civil society actors created their own "action space" which ultimately triggered social legitimacy. In addition to civil society, the actions of local authorities are found to contribute towards social legitimacy as well. To narrow the gap, the identified intervention strategies are discussed within the scope of land policy, land tenure security and land development.
\end{abstract}

Keywords: Informal settlements, "action space", Legal legitimacy, Social legitimacy, Intervention strategies 


\subsection{Introduction}

Urban land governance faces major challenges in handling the issues of informal settlements as there is an unclear demarcation of acceptance and non-acceptance of these settlements. The challenges are basically a) how to manage existing informal settlements and their future growth, and b) how to balance diverse stakeholder's needs in solving land and housing issues of informal settlements and how to provide land rights to informal settlers (Palmer et al., 2009). Informal settlements are often born due to lack of access to land to fulfill the shelter needs. The lack of access to shelter is generally attributed to the expensive and lengthy processes of land and housing markets often caused by weak land governance (Potsiou et al., 2009). Due to the lack of access to land for shelter, the migrant population starts illegal occupancy of vacant land - often public land -where there is less fear of being dislodged than from private land (Aiken, 1981). The issues in informal settlements are multidimensional covering socio-economic, physical and legal aspects. The socio-economic characteristics relate to health, literacy, and employment; physical characteristics refer to public services such as water supply, electricity and drainage; legal characteristics refer to legal documents for occupied land (Wekesa et al., 2011). Lack of legal recognition due to the absence of legal documents of occupied land is a dominant variable for informality. Indeed, informality does not just occur outside the formal system, instead it occurs due to weaknesses of the formal structure such as land laws and policies (Porter et al., 2011). Conceptually, urban informal settlement is in a "grey space" (Wigle, 2014), the space positioned between "whiteness" of legality and "blackness" of eviction. This grey space represents a blurred boundary between legal/not legal and acceptable/not acceptable (Roy, 2009). In this grey space, there exist some types of legitimacy of informal settlement from the perspective of land rights (Palmer et al., 2009). Within this dyadic dichotomy, this paper argues that informal settlements are in fact intertwined with several sorts of legitimacy, and the challenges for urban land governance are embedded in legitimacy. The challenges that governance structures face as regards urban land governance is about enhancing legitimacy (Stoker, 1998) for providing security to informal settlers. When talking about legitimacy, one can refer to different aspects. In this paper, we refer to two types of legitimacy: legal legitimacy and social legitimacy (Thomas, 2013). Several studies revealed that despite the lack of legal legitimacy, such as legal land title of occupied land, the settlers perceive some degree of tenure security that is reflected in their improvement of dwellings (Earle, 2014; Payne et al., 2009; Usamah, 2013). The rationale of this perceived security is described as an outcome of the tolerant attitude towards land invasion, the provision of utility services from local authority and the development program of non-government organizations (Durand-Lasserve, 2006). The perceived tenure security relates to a perceived land right of occupied land that comes from social legitimacy (Palmer et al., 
2009). In the context of land issue, Deininger (2003) mentioned "Failure to give legal backings to land administration institutions that enjoy social legitimacy can undermine the ability of people to draw on anything more than informal mechanism for enforcement". Further, Thomas (2013) highlighted that it is important to minimize the gap between legal legitimacy and social legitimacy for the effectiveness of a legal system. Within this context, enhanced legitimacy refers to the minimized gap between legal legitimacy and social legitimacy. So far, no study has been carried out along the lines of enhanced legitimacy for informal settlements.

To understand the gap between legal legitimacy and social legitimacy, it is important to analyze the governance patterns in informal settlements. The governance patterns basically refer to the actions of various actors like government, civil society and market actors and their dominant position in that period of action (Foxon et al., 2009). The scope of this study lies in the interaction between government and civil society. As observed in the literatures, Rip and Joly (2012) described that governance is connected with a space in which an interaction between actors takes place, Gaventa (2005) explained governance patterns by referring to space as invited space or claimed/created space in the policy dialogue with civil society and Harpham and Boateng (1997) mentioned the importance of locating "action space" for civil society in urban governance. However, the analytical concept of "action space" to analyze governance patterns was introduced by Foxon et al. (2009). Though the concept considers three key actors, government, civil society and market, the framework provides the potential to analyze the interaction between each combination of actors through their interrelationship (Foxon et al., 2009). The most effective enroller defines the dominant form of governance in that period of action by pulling the "action space" towards their logic which results in some sort of legitimacy from that action. This concept has added value to analyze the dynamism in governance patterns by analyzing the push and pull within the "action space" between government and civil society. Therefore, we refer to the concept of "action space" in our study to analyze the interaction between government and civil society that has resulted in various types of legitimacy, ultimately creating the gap. Therefore, the aim of this paper is twofold: a) to analyze how the "action space" of government and civil society creates a gap between legal legitimacy and social legitimacy and b) to identify intervention strategies to minimize the gap. We adopted a case study approach as research methodology and selected two case studies in Nepal. In the first case, "action space" and its relation to legitimacy are analyzed and in the second case we identify intervention strategies. The second section presents a definition of informal settlement in the country context. In the third section, the research methodology is presented. The fourth section presents the theoretical background on urban land governance and legitimacy, followed by the theoretical base on elements of urban land governance and 
intervention strategies in the fifth section. Two case studies are subsequently presented in the sixth section The seventh section presents the discussion on the "action space" of the actors that contributed to the gap between the legal and social legitimacy and relevant intervention strategies to minimize the gap. Finally, this paper concludes with a reflection on intervention strategies and the further research that is needed.

\subsection{Informal Settlements in Context}

The term "informal settlements" has a broad meaning and is known in various terms such as slums (Huchzermeyer and Karam, 2006), shanty towns (Lloyd,1979), squatter settlements (Willis, 2009). Slums are characterized by lack of basic services and durable housing conditions, insufficient living spaces and sanitation, insecure tenure, poverty and exclusion (UN-HABITAT 2005). Shanty towns are characterized by low quality buildings made out of materials (such as corrugated irons, plastic, and cardboard), lack of proper utilities facilities. Squatter settlements resemble the physical characteristic of slums and, shanty towns but they lack legal land ownership documents. These settlements are usually named differently in different countries - bustees (in India), favelas (in Brazil), pueblo (in Peru), kampong (in Indonesia), barongbarong (in Philippines), setinggan (in Malaysia), chumchaon bukruk (in Thailand) and gecekondu (in Turkey) (Suditu and Vâlceanu, 2013; Willis, 2009). In Nepal, informal settlements that resemble the characteristic of "squatter settlements" are termed "Sukumbashi Basti", meaning the settlements without official land ownership certificates. Settlers are termed "Sukumbashi". Based on official norms, "Sukumbasi" are those inhabitants who do not have legally occupied land elsewhere in the country. Besides "Sukumbasi" there are some older settlers referred to as "Swabasi", a term that literally means "dwellers staying by themselves", and while these settlers also lack legal land documents of their existence in the occupied areas, they do not refer to themselves as "Sukumbasi" (Tanaka, 2009). There is an unclear official definition for "Sukumbasi" and settlers do not accept the term "Sukumbasi" and its official translation (Moffat and Finnis, 2005). To overcome confusion, this paper uses the term "informal settlements" which refers to all settlements without formal land tenure.

\subsection{Research Methodology}

The research approach underpinning this paper is based on a case study approach (Yin, 2003) with a qualitative approach (Silverman, 2010) and the author's indepth observations. Two case studies are conducted. In the first case study, the concept of "action space" (Foxon, 2013; Foxon et al., 2009) is adopted as an analytical framework of the governance patterns and identifies the gap between legal legitimacy and social legitimacy within the scope of land and shelter policies, land tenure security and land development. In the second 
case study, we use the intervention strategies - being a prescriptive model or tools for solving existing or perceived problems (Elangovan, 1998) in informal settlement areas - to minimize the gap with bottom up approach. The framework consisting of urban land governance elements and indicators that is developed is based on literature. The settlers' preferences for urban land governance indicators were collected by applying a 5 point Likert scale.

A SWOT (strengths, weakness, opportunities and threats) analysis (Helms and Nixon, 2010) was carried out to obtain feasible intervention strategies in informal settlements. The SWOT approach is considered as a powerful strategic and environmental analysis tool applied to identify internal and external strategic factors (Babaesmailli et al., 2012). Though some studies mention that conventional SWOT analysis has some shortcomings of ranking SWOT factors and strategies (Catron et al., 2013; Shakoor Shahabi et al., 2014; Yüksel and Dagdeviren, 2007), this approach has been applied successfully to a broad array of disciplines by integrating conventional SWOT approaches with other analysis approaches. For example, Catron et al. (2013) have applied SWOTANP (Analytical Network Process) technique to assess the bioenergy situation in Kentucky; Comino and Ferretti (2016) have used the SWOT approach with a spatial indicator to support the strategic management of complex territorial systems; Shrestha et al. (2004) have employed SWOT-AHP (Analytic Hierarchy Process) to assess the effect of environmental, economic and social factors relating to decisions in silvopasture adoption. Similarly, by using SWOT approach Yan et al. (2015) have analysed land consolidation in China based upon SW and OT strategy while Yuan (2013) has used the SWOT approach for policy recommendation for construction waste management in Shenzhen city of south China based on the principle of 'maximizing strength and opportunities, transforming weakness to strengths, and minimizing threats'. It is evidently demonstrated by those studies that the SWOT analysis has a potential for investigating a problem from a strategic perspective and develop intervention strategies. Therefore, based on the SWOT factors with an approach 'maximizing strength and opportunities, transforming weakness to strengths, and minimizing threats' (Yuan, 2013), intervention strategies that minimize the gap between legal legitimacy and social legitimacy in informal settlements are identified in this study.

The first case study area is the "Srinagarka" informal settlement, located in the sub-metropolitan city of Biratnagar. The city is a main economic, industrial and administrative hub, situated in Koshi Zone of Morang district, in the eastern development region of Nepal. About $15 \%$ of the total households $(38,358)$ in the city are identified as informal settlers (Biratnagar Muncipality, 2007). The "Srinagarka" settlement sits along the bank of the Singhe river and consists of 86 households. This case is considered to analyze the gap between 
legal and social legitimacy because the government has taken the initiative to distribute identity cards in this settlement.

The second case study area is the "Bansighat" informal settlement, located in the metropolitan city of Kathmandu, the national capital, situated in Bagmati Zone of the Kathmandu district, in the central development region of Nepal. Within two decades (1985 to 2010), the number of informal settlements in Kathmandu increased by 17 to 51 informal settlements including evicted settlements (Ministry of Physical Planning \& Works, 2010). The "Bansighat" settlement sits along the bank of the Bagmati River and consists of 152 households. This case is considered to identify an intervention strategy because the government is considering an intervention to relocate the settlement.

Prior to the fieldwork in both informal settlements, the authors developed contacts with the leaders of Society for Preservation of Shelters and Habitations in Nepal (SPOSH-Nepal) and Nepal Women's Unity Society (NEMS). SPOSH Nepal and NEMS are informal settlers' federations advocating for shelter rights and creating a social network of informal settlers of various districts (Shrestha et al., 2014a; Tanaka, 2009). The empirical data for both case study areas were collected using open interviews with the government (27 respondents), NGOs (5 respondents), the INGO (2 respondents), reports from government and nongovernment organizations and unpublished literature. Interviews with 30 settlers followed by group discussion were carried out in "Srinagarka" and with 47 settlers in "Bansighat".

\subsection{Urban Land Governance and Legitimacy}

\section{Governance, "action space" and Legitimacy}

The governance concept recognizes links between various government agencies as well as shifting responsibilities between public and private sectors. Each organization is dependent upon other organizations for resources and has to exchange its resources to achieve its goals (Rhodes, 2007; Stoker, 1998). Governments normally depend on the societal actors to achieve their goals, as the private actors, civil society groups and citizens have important resources as well as power to obstruct policy interventions. It is only through collaborative actions that societal problems can be negotiated and resolved (Klijn, 2008). Therefore, the governance concept emphasizes the involvement of private and civil society, besides government organization, in service delivery and resource allocation (Harpham and Boateng, 1997). The involvement of the various actors and their actions defines the governance patterns i.e. state dominant, civil society dominant or market dominant and "action space" is an analytical concept that allows analysis of the various governance patterns (Foxon et al., 2009). The pictorial representation of the 
analytical framework is shown in Figure 6 . The concept is applied in order to understand the actions of the three key groups of actors (government, market and civil society) and their underlying logic for action. Here, logic refers to how each actor frames the specified problem according to its understanding. Ideally, each actor tries to pull the "center of gravity" of the action towards its logic trying to become the dominant actor within the governance patterns and form some sort of legitimacy from that action. Legitimacy is thus described as "a generalized perception or assumption that the actions of an entity are desirable, proper, or appropriate within some socially constructed systems of norms, values, beliefs and definitions" (Suchman, 1995). It is about tacit recognition, support, acceptance by those who are governed and has its context in different forms such as legal legitimacy and social legitimacy (Thomas, 2013).

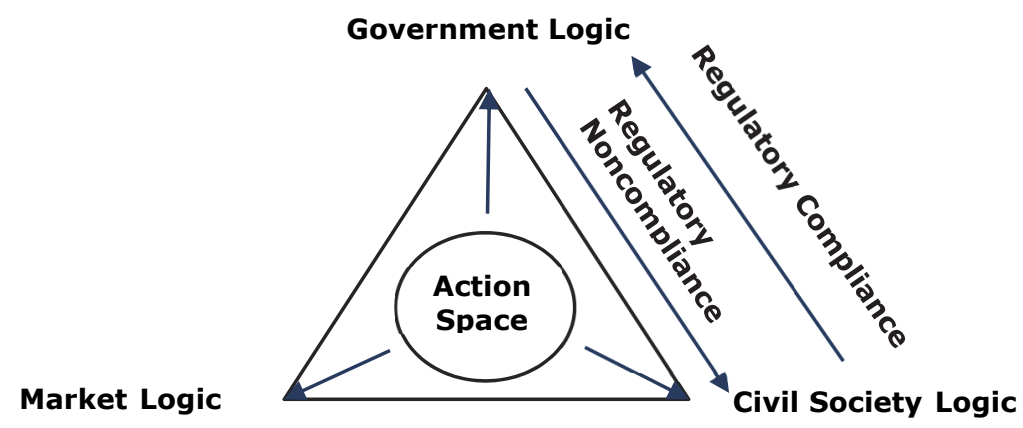

Figure 6: Analytical framework of "Action Space" to analyse governance pattern between government and civil society actors

adopted from (Foxon et al., 2009) and modified by author

Legal legitimacy bounds up with the normative framework, with emphasis on national laws, policy, and rules. The action of actors in the governance structure triggers legal legitimacy when the actions are within legal norms and rules. Land policy and policy instruments determine space and boundaries for action i.e. "action space", in which various actors play their specific roles within the specified space (Bartu Candan and Kolluoğlu, 2015). Government actors can pull the "action space" towards their logic, triggering legal legitimacy and the other actors simply comply within the regulatory framework and are supportive to enable policies when there is "regulatory compliance" (Foxon et al., 2009). For example, when government actions to regularize informal settlements are executed within the legal framework and policy is compatible with the social values and norms, then other actors, such as civil society, will support the policy and its implementation. Unlike legal legitimacy, social legitimacy does not rely on the legal framework. It is an empirical concept that considers legitimacy as a social fact. The actions of actors in the governance structure trigger social legitimacy when there is a belief that the actions of an entity are morally justifiable, even though there is lack of strong legal norms 
to support this action. In fact, social legitimacy is derived from the socially accepted social norms (Rakodi and Leduka, 2004). It is also derived from broad societal acceptance, but without legal recognition (Palmer et al., 2009). When we link this definition with the concept of "action space", we can see that social legitimacy is derived from action of actors under socially accepted norms. The "regulatory noncompliance" leads to a pull of the "action space" towards the logic of civil society. For example, limited access to land for housing via the formal sector results in the informal approach of housing which then has social legitimacy. It is morally justifiable from a human rights perspective as the Universal Declaration of Human Rights states that "everyone has the right to adequate standard of living including housing" (Enemark et al., 2014).

\section{Urban Land Governance and Legal Legitimacy of Informal Settlement}

The "action space" of actors refers to the contribution towards legal legitimacy in urban land governance when the action is executed within the legal framework. A claim to occupied land by informal settlers has legal legitimacy when it is recognized in land policy and land law. This recognition of a claim shows the "action space" of the state for recognizing informal settlements, meaning that the rights for the occupants are acknowledged and that the government recognizes the settlements in legal terms (Aguilar and Santos, 2011). When the "action space" from the government is included in a policy or a law that recognizes informal settlements, the actions of other actors like civil society groups can easily comply with the logic of the government when achieving legal legitimacy of informal settlements. The settlers of informal settlements where the eviction threat is high seek for legal tenure security. Legal tenure security gives legal status to tenure and the protection is backed up by the government, which results in legal legitimacy for the occupied land. Mostly, legal tenure security, which is categorized as de jure, is achieved by allocating land hold or possessory titles to the informal settlers.

Various studies show that the practice of providing individual complete titles turns out to be ineffective in the long run. The legal security of tenure is generally attributed to the property rights and the absence of this right leaves the settlers with legal insecurity of tenure (Van Gelder, 2010b). However, lack of legal instruments for the government to recognize informal settlements leads to lack of governments "action space" for legal legitimacy.

\section{Urban Land Governance and Social Legitimacy of Informal Settlement}

The "action space" of the various actors in urban land governance in order to overcome legal shortcomings often triggers social legitimacy. According to Durand-Lasserve (2006), there is a global shift in government action towards 
informal settlements, from non- recognition in the 1960's, to repression in the form of eviction (1970's and 1980's), to tolerance in 1990's. The tolerant attitude of government appears due to ineffective implementation of land and housing policies for low-income groups and the lack of land use regulations, which restricts land invasion for informal settlements (Aguilar and Santos, 2011). The lack of "action space" for government in providing low-income housing leaves the low-income residents no other options than the informal mechanism for housing. When the relevant authorities fail to take timely actions against land use violation, the settlers occupy land for a long time. Long term tolerance of these settlements by the relevant authorities as well as by nearby formal neighborhoods, ultimately creates social legitimacy for informal settlers (Earle, 2014). Similarly, social movements from international organizations, NGOs are likely to pull the "action space". In this way, they practice social legitimacy for security of tenure that protects settlers from eviction. This reveals from the definition of security of tenure proposed by UNCHS 1999, individuals "[..] have secure tenure when they are protected from involuntary removal from their land or residence, except in exceptional circumstances, and then only by means of a known and agreed legal procedure, which must itself be objective, equally applicable, contestable and independent [..]"cited from (Durand-Lasserve and Royston, 2002b).

The success in long term land occupancy without legal action from the concerned authority brings the perception of security that settlers would not get evicted and hence they perceive land rights in the occupied land (Shrestha, 2013). According to Palmer et al. (2009), the perceived land rights that generate from perceived tenure security ultimately refers to social legitimacy. Van Gelder (2010b) categorized tenure security in informal settlements as de facto and perceived. The perceived tenure security is a level of tenure security perceived by the settlers according to the likelihood of eviction. In contrast, de facto tenure security is the outcome of long-term occupation, size of settlement, level and cohesion of community organization. Indeed, land tenure security (perceived or de facto), is the ultimate belief that comes from the social norms and values that occupying a piece of land is morally justifiable. Further, social norms for buying and selling of a piece of occupied land reinforce the perceived tenure security to new potential buyers. Similarly, the settlers' "action space" in the form of tacit approval of their actions by formal authorities also contribute towards social legitimacy of this settlement (Nkurunziza, 2008; Van Gelder, 2010a). The tacit approval can be acceptance of informal institutions for infrastructure provision, electricity bills, and informal purchase contracts In short; the "action space" of various actors outside the legal framework of land rights ultimately triggers social legitimacy. 


\subsection{Interventions in Informal Settlements and Elements of Urban Land Governance}

In developing countries, the government normally uses land policy intervention to regulate access, use and development of land in informal settlements. The intervention measures for the shelter issue are generally a provision of housing subsidy, a reduction of building standards, the use of low cost technologies and self-modes of housing delivery (Wekesa et al., 2011). Though interventions towards informal settlements in urban areas are addressed as part of the shelter issue, it is often a struggle with regard to land to deal with access to land for housing or to deliver legal documents of already occupied land (Satterthwaite,2009). Therefore, land policy intervention seem to be an entry point to tackle the issue of informal settlements i.e. access and allocation of land for housing for marginalized groups. The land policy determines the forms of land rights and level of tenure security that citizens can have. The land policy review of nine African and Asian countries shows that they contain recognition of informal settlements and avoidance of forced evictions (Van der Molen et al., 2008). Eviction is not an appropriate intervention as the political costs are often high both internally and at an international level (Durand-Lasserve and Royston, 2002a). Therefore, there is a need of a paradigm shift in intervention from a reactive approach to preventive measures to address the need for access to land for housing for the poor as a long term solution (Augustinus, 2010). The reactive measure addressed in the land policies of nine African and Asian countries is to regularize existing settlements by upgrading or relocating the settlements in environmentally vulnerable land such as flood prone zones and the preventive measures are to constrain further growth of informal settlements through land use planning (Van der Molen et al., 2008).

However, it is important to refer to elements of good urban land governance to understand interventions in informal settlements.

The two key thematic areas of land governance, the legal and policy framework and urban land use planning in the land governance assessment framework (Deininger et al., 2012), are relevant in identifying intervention strategies in informal settlements. The importance of the legal and institutional framework in addressing the issue of informal settlements is clearly mentioned in the study of Huchzermeyer (2003) and Wekesa et al. (2011). Weaknesses in the legal and institutional framework usually make it difficult to enforce interventions in the informal settlements. Therefore, recognition of land rights, enforcement of land rights and tools for recognition of land rights explained within the legal and institutional framework by Deininger et al. (2012) are selected elements of good urban land governance. Similarly, Aguilar and Santos (2011) and Shabane et al. (2011) have shown the importance of land use planning to tackle the issue of informal settlements. Land use planning is associated with land use control like restriction and responsibilities. Therefore, 
transparency in land use control and equity in decision making with a participatory approach are considered urban land governance elements. Table 1 shows the relevant elements and indicators of good urban land governance within the framework of land governance assessment framework (Deininger et al., 2012). A brief explanation of each element is further explained.

Recognition of the land rights of existing land users in informal settlements is important at policy level for legal legitimacy. The legal recognition of this right should be flexible enough to accommodate different types of rights that can be upgraded. It is indicated that freehold title is not sustainable for tenure security in informal settlement (Payne et al., 2009). One of the dominant rationales behind this is the risk of market eviction. In this regard, the Global Land Tool Network (GLTN) has proposed the use of a continuum of land rights to protect tenure security of the poor, including informal settlers (UN-HABITAT and GLTN, 2008). The approach of a continuum of land rights provides a path for the stepwise increment in legal legitimacy narrowing the gap with social legitimacy.

A tool for recognition of existing land rights is an important element of urban land governance in informal settlements, because lack of an appropriate mechanism to identify genuine right holders can carry a significant risk of land being concentrated in the hands of well-connected and powerful elites (Deininger et al.,2012). Recognition of land rights requires an authentic proof of land occupation which is difficult to obtain in informal settlements. Therefore, alternative forms of evidence like electricity bills, tax receipts and long term occupancy can be approaches of recognition of land rights of settlers (Deininger et al., 2012). In short, the Social Tenure Domain Model (STDM) (Augustinus et al., 2006)2006 is identified as a tool to support the government in recognizing various types of social land tenures in informal settlements.

Transparency in land use control is another element of urban land governance which requires a participatory approach in land use planning and regulation. $A$ participatory approach of implementing land use regulation during land development implies that the legal requirements and standards, for example, minimum plot size, building standards and infrastructure standards should be affordable and compliant to the social and economic structure of settlement (Deininger et al., 2012). Equity in land related decision making is another element of urban land governance intervention strategies. Equity in decision making is a societal goal aimed at fair implementation of a policy without considering any form of preferential treatment of certain beneficiaries (Stone and Norton, 1997). Therefore, intervention strategies require the incorporation of social consensus and participation of informal settlers in decision making of any land development plan (Deininger et al., 2012). 
Table 1: Elements and Indicators of good urban land governance intervention strategies

\begin{tabular}{|l|l|}
\hline $\begin{array}{l}\text { Elements of urban land } \\
\text { governance }\end{array}$ & Indicators of urban land governance \\
\hline Recognition of land rights & $\begin{array}{l}\text { Recognition of settlements } \\
\text { Grant of land use rights } \\
\text { Settlement rehabilitation for improved land } \\
\text { tenure security }\end{array}$ \\
\hline Land rights enforcement & Integrated relocation and compensation policy \\
\hline Tool for land rights & $\begin{array}{l}\text { Grant of secure tenure based on long term } \\
\text { occupancy }\end{array}$ \\
\hline Transparency in land use control & $\begin{array}{l}\text { Attention to public input concerning land use } \\
\text { planning }\end{array}$ \\
\hline Equity in decision making & Participatory urban planning \\
\hline
\end{tabular}

\subsection{Case Studies}

\section{Case Study 1: Urban Land Governance and Legitimacy (Informal Settlement: "Srinagarka")}

\section{i) Land and Shelter Policies and Legitimacy}

The interviews with the government officials revealed that the integrated National land policy is in a draft stage and the legal frameworks for land are the Land Act, 1964 and Land Revenue Act, 1978. Formulating a national land policy and implementing the national land use policy are mentioned in the thirteenth plan of National Planning Commission (NPC). The Land Use Policy 2013, approved by parliament, categorized land into six specific zones (agricultural, residential, commercial, industrial, forest and public areas). The Land Use Policy includes the need to identify adequate land to accommodate landless communities including those who have limited access to land, to discourage land development and to encourage relocation of settlements in vulnerable areas. Yet, there is no explicit mention of regularizing informal settlement or security of tenure. Similarly, the Land Act 1964 and Land Revenue Act, 1978, lack a clear provision on informal occupation of government and public land. However, the Land Revenue Act contains a penalty for registering government or public land for individual benefit, but it does not indicate any legal actions for informal settlement. The Urban Policy 2007 includes the provision of affordable land and dwelling units to low income groups (Ministry of Physical Planning and Works, 2007). Similarly, National Shelter Policy 2012 (Ministry of Urban Development, 2012) reflects on the upgrading and relocating of informal settlements under collective ownership of land, distribution of identity cards and allocation of plots for low cost dwelling units. However, ineffective implementation of the shelter policy can be illustrated by the failure to resettle and manage one of the informal settlement in Kathmandu Valley (Shrestha et al., 2014a).The existing land laws do not 
allow government authorities to recognize the informal settlements on government land. The doctrine of "adverse possession" is not recognized in Nepalese law, but there is a provision for issuing identity cards to informal settlers as beneficiaries of land rights. This is done by the politically appointed government commission known as Squatters Problem Resolution Commission (SPRC). SPRC is mandated to distribute government land and they expect 10 years of occupancy to qualify for the declaration of beneficiaries of land rights. Eleven SPRCs were formed in total until the year 2013. These commissions already distributed 73,3424 hectares of land to 71,512 informal households in various districts (MoLRM, 2013). The lack of a policy that recognizes informal settlements that exist on government land means that "Srinagarka" settlement are not within the legal framework i.e. lack legal legitimacy. The interview with the local authority revealed that due to unclear institutional mandate, the local authority has developed a tolerant attitude towards informal land encroachment, evidenced by the existence of "Srinagarka" for several decades. In addition, lack of an effective policy for access to and allocation of affordable land and housing for low-income groups left the local government with no alternative than to tolerate the settlement. It reveals that lack of a land policy and an effective implementation of the shelter policy lead the informal settlements towards social legitimacy.

\section{ii) Land Tenure Security and Legitimacy}

The settlers do not have a legal document of occupied land (see Table 2). Twenty three settlers mentioned that they have squatter identity cards distributed by the $11^{\text {th }}$ SPRC and five settlers do not possess identity cards. This commission distributed 2,1343 identity cards in case study district (MoLRM, 2013). However, the interview with government officials revealed that the distribution of identity cards was carried out in an ad-hoc way without identification of the genuine settlers. The criteria set for genuine settlers are that there should not be any registered land in the settler/settlers' family members name in the country and that they stayed for more than ten years on the land. Yet, it seems difficult to verify the criteria due to current way of recording land information. Besides the identity cards of the $11^{\text {th }}$ SPRC, the settlers have identity cards issued by SPOSH-Nepal as well. As indicated in Table 2, most of the settlers mentioned that they have been living for more than 20 years on the land, and they believe that they acquired land rights after staying for decades. Regarding access to a piece of land eight respondents mentioned they purchased the piece of place from the previous settlers, 16 occupied the place by themselves, two were to occupy the land referred by others, and lastly three had the place given by the relatives. This study shows that there is a trend of informal buying and selling of houses and it is for the occupied space that money is being paid. The proof of buying and selling of an occupied space is guaranteed by the presence of the community head and 
witnesses. Regarding perceived tenure security, 10 settlers out of 30 settlers mentioned they feel protected against eviction while 19 settlers do not feel secure. Indeed, in a group discussion, settlers mentioned that they oppose any government intervention of eviction as they already have identity cards distributed by the government itself. This identity card is proof of their perceived land rights. Similarly, regarding humiliation from the formal settlers, 21 out of 30 respondents mentioned that they discriminate them and do not count them as legitimate occupiers.

Table 2: Empirical data of "Srinagarka" informal settlement in security tenure aspect and actors action

\begin{tabular}{|c|c|c|}
\hline $\begin{array}{c}\text { Land Tenure } \\
\text { Security Aspect }\end{array}$ & Results & Actor's and action \\
\hline $\begin{array}{l}\text { Legal document of } \\
\text { occupied land }\end{array}$ & $\begin{array}{l}\text { The settlers do not have a legal } \\
\text { document of occupied land }\end{array}$ & $\begin{array}{l}\text { SPRC has not distributed } \\
\text { any land ownership } \\
\text { certificate }\end{array}$ \\
\hline $\begin{array}{lll}\text { Identity } & \text { card } & \text { by } \\
\text { SPOSH } & & \end{array}$ & $\begin{array}{l}\text { The settlers have an identity card } \\
\text { from SPOSH }\end{array}$ & $\begin{array}{l}\text { Distributed by Squatters } \\
\text { Federation }\end{array}$ \\
\hline $\begin{array}{l}\text { Squatter identity } \\
\text { card }\end{array}$ & $\begin{array}{l}23 \text { respondents (Yes); } 5 \text { respondents } \\
\text { (No); } 2 \text { respondents (don't know) }\end{array}$ & Distributed by SPRC \\
\hline Settled duration & $\begin{array}{lll}3 \text { respondents (< } 5 \text { years); } & 1 \\
\text { respondent ( } 5 \text { to } 10 \text { years); } & 7 \\
\text { respondents ( } 10 \text { to } 15 \text { years); } & 2 \\
\text { respondents ( } 15 \text { to } 20 \text { years); } 15 \\
\text { respondents (more than } 20 \text { years) } ; 2 \\
\text { respondents (No answer) }\end{array}$ & $\begin{array}{l}\text { Lack of timely action from } \\
\text { concerned local authority } \\
\text { to clear the settlement }\end{array}$ \\
\hline $\begin{array}{l}\text { Access to piece of } \\
\text { occupied land }\end{array}$ & $\begin{array}{l}8 \text { respondents (Bought from } \\
\text { somebody); } 16 \text { respondents (Found } \\
\text { ourselves); } 3 \text { respondents (Given by } \\
\text { relatives) } ; 2 \text { respondents (Referred } \\
\text { by others) } \\
1 \text { respondent ( No answer) } \\
\end{array}$ & $\begin{array}{l}\text { Buying and selling of } \\
\text { occupied land }\end{array}$ \\
\hline $\begin{array}{l}\text { Secure } \\
\text { eviction }\end{array}$ & $\begin{array}{l}10 \text { respondents (Yes); } 19 \\
\text { respondents (No); 1respondent (No } \\
\text { answer) }\end{array}$ & Settlers perception \\
\hline $\begin{array}{l}\text { Humiliation from } \\
\text { formal settlers }\end{array}$ & $\begin{array}{l}21 \text { respondents (Yes); } 6 \text { respondents } \\
\text { (No); } 3 \text { respondents (No answer) }\end{array}$ & Action of formal settlers \\
\hline
\end{tabular}

Source: Field visit in December $2013^{5}$

The study shows that the "action space" of SPRC as well as the settlers' federation has triggered social legitimacy. The 11th SPRC does not have a mandate to distribute land titles, only to distribute identity cards. Nevertheless, the action of this commission contributed towards social legitimacy among settlers themselves and it suggests government acceptance of their land rights. Similarly, the distribution of identity cards by the squatters' federation somehow reflects an increasing network of settlers. The number of district level federations is found to have increased from a single central level office of both SPOSH and NEMS in 2000 to 29 of SPOSH and 19 of NMES in 2008. The

${ }^{5}$ The "Srinagarka" resides in Morang District which is less effected district by the earth quakes that occurred on $25^{\text {th }}$ April and $12^{\text {th }}$ May 2015 
network of these federations is found in the case study city as well. The interview with the head of SPOSH for case district mentioned that the increasing social network is their weapon to fight eviction. The social network contributes to social legitimacy of informal settlements. Likewise, looking to the action of formal settlers, we see there is no explicit mention of any protest to clear the informal settlement, except for some individual stigma for informal settlers. In fact, the informal settlement was settled prior to the formal settlement. The acceptance by the formal neighborhood somehow triggers the social legitimacy as well.

\section{iii) Land Development and Legitimacy}

The settlement developed in an incremental way and found some level of tenure security. Statements of settlers like "we have stayed here when there is nothing but now we have managed to improve our community, the government cannot evict us and we will not go either" reflect that settlers already perceive de facto tenure security. The houses were built according to settler's local knowledge without following the legal norms. Twenty four out of 30 respondents (see table 3 ) mentioned that they are not obliged to follow any building regulations. The road along the settlement was developed at the initiative of settlers themselves. Two NGOs, -Rural Road Network (RRN) and "Paropakar Samuha"- and the municipality contributed to the road development (DUDBC, 2008). The interview with the head of SPOSH for case district revealed that the district level settlers' federation has managed to get an electricity grid connection after lobbying with the concerned authorities. Similarly, the local government revealed that the utility services have been provided based on every citizens' right to basic services. The process to get electricity grid connection went as follows: a) submitting an application to the president of Tole Lane Organization (TLO), which is a community organization b) obtaining recommendation from the president of the urban community (representation of TLOs) and the former ward president, c) obtaining a recommendation from the municipality and registering the application by paying the application fee, d) finally submitting an application to Nepal Electricity Authority with payment of meter costs. In this whole procedure, the identity card of SPOSH is required. Since the settlers do not have legal documents of occupied land, the settlers were required to deposit of Rs. 1000 (equivalent to 1 US dollar) as a guarantee (DUDBC, 2008).

Two NGOs, Lumanti Support Group for Shelter (Tanaka, 2009) and Water Aid, have launched jointly the WASH (Water, Sanitation and Hygiene) program. The objective of the program is to rehabilitate tube well (a source of drinking water) to prevent ground water contamination, to encourage the construction of toilets and to raise awareness in sanitation. Out of 86 households, 70 households have a toilet and 16 do not have a toilet. Similarly, 62 households 
have a tube well and 24 households do not have one. According to the Water Aid program manager, water tap and sewage line connection needs land ownership certificate. The 2013 (fifth South Asian Conference on Sanitation) SACOSAN-V declaration, calls to "Recognize the importance of sustainable environmental sanitation and hygiene in urban areas [....] for all urban dwellers, regardless of tenure (Government of Nepal, 2013)". This shows that utilities services like drainage and water pipe connection are justifiable for informal settlements.

Table 3 : Empirical data in "Srinagarka" in land development aspect and actors action

\begin{tabular}{|c|c|c|}
\hline $\begin{array}{c}\text { Land } \\
\text { Development } \\
\text { Aspect }\end{array}$ & Results & Actors Action \\
\hline $\begin{array}{l}\text { Permission to build } \\
\text { house }\end{array}$ & $\begin{array}{l}24 \text { respondents (No); } 6 \\
\text { respondents (don't know) }\end{array}$ & $\begin{array}{l}\text { Municipality is responsible } \\
\text { for building by laws }\end{array}$ \\
\hline Water supply/ toilet & $\begin{array}{l}\text { Households with toilet (70); } \\
\text { Households without } \\
\text { toilet(16); Households with } \\
\text { tube well }(62) ; \\
\text { Households without tube } \\
\text { well (24) }\end{array}$ & $\begin{array}{l}\text { Lumanti Support Group for } \\
\text { Shelter and Water Aid are } \\
\text { active for WASH (Water } \\
\text { Sanitation Hygiene) program }\end{array}$ \\
\hline Electricity & Electricity is available & $\begin{array}{l}\text { Able to get connection after } \\
\text { recommendation by local } \\
\text { government }\end{array}$ \\
\hline Road & $\begin{array}{l}\text { During field visit, first } \\
\text { author observed the road } \\
\text { along the settlement }\end{array}$ & $\begin{array}{l}\text { Settlers involvement, } \\
\text { financial support from "RRN" } \\
\text { NGO, "Paropakar" NGO }\end{array}$ \\
\hline School & $\begin{array}{l}\text { During field visit, author } \\
\text { observed the school } \\
\text { building }\end{array}$ & $\begin{array}{l}\text { "Paropakar" NGO contributed } \\
\text { to the school }\end{array}$ \\
\hline
\end{tabular}

Source: Field visit on the year 2013

Overall the case study shows that the "action space" of the informal settlers' federation in the process of obtaining an electricity connection as well as the local authorities' support of this, contributes to social legitimacy as the electricity is provided on the basis of the social value that every citizen has right to basic services. Normally a land ownership certificate is needed for electricity connection and is waived here. Similarly, the actions of NGOs in development activities such as road, school and awareness programs contribute to social legitimacy even though the settlements are not in the legal framework. Finally, this case study shows that there are gaps between legal and social legitimacy in the land and shelter policies, the perceptions of tenure security and the land development processes.

\section{Case Study 2: Urban Land Governance and Intervention Strategies (Informal Settlement: "Bansighat")}

After having understood the above gaps between the legal and social legitimacy, another case study in the Bansighat settlement in Kathmandu was 
studied. The interviews with the government respondents reveal that relocation of the Bansighat settlement is important because the settlement on the river bank is not environmentally suitable for residential use. Therefore, relocation is a potential intervention from the government perspective.

Table 4 shows the results of the urban land governance indicators based on interviews of the settlers (47 respondents). For each indicator, a weight for each question is assigned on a six point Likert scale ranging from Strongly Agree (SA),Agree (A), Not Agree or Disagree (NAD), Disagree (D), to Strongly Disagree (SD).

Table 4: "Bansighat" settlers' views in urban land governance indicators

\begin{tabular}{|c|c|c|c|c|c|c|c|c|}
\hline $\begin{array}{l}\text { Elements of } \\
\text { urban land } \\
\text { governance }\end{array}$ & $\begin{array}{l}\text { Urban land } \\
\text { governance } \\
\text { indicators }\end{array}$ & Questions & $\begin{array}{l}\text { SA } \\
(\%)\end{array}$ & $\begin{array}{l}\text { A } \\
(\%)\end{array}$ & $\begin{array}{l}\text { NAD } \\
(\%)\end{array}$ & $\begin{array}{l}\mathrm{D} \\
(\%)\end{array}$ & $\begin{array}{l}\text { SD } \\
(\%)\end{array}$ & $\begin{array}{l}\text { Respond } \\
\text { ents }\end{array}$ \\
\hline \multirow{3}{*}{$\begin{array}{l}\text { Recognition of } \\
\text { land rights }\end{array}$} & $\begin{array}{l}\text { Recognition of } \\
\text { settlement }\end{array}$ & $\begin{array}{l}\text { Do you agree if } \\
\text { the government } \\
\text { recognizes the } \\
\text { existence of this } \\
\text { settlement? }\end{array}$ & 59.5 & 10.6 & 12.8 & 4.2 & 12.8 & 47 \\
\hline & $\begin{array}{l}\text { Grant of land } \\
\text { use rights }\end{array}$ & $\begin{array}{l}\text { Do you agree if } \\
\text { the government } \\
\text { grants use rights } \\
\text { in a certain year } \\
\text { for you? }\end{array}$ & 13.0 & 58.7 & 13.0 & 4.3 & 10.9 & 46 \\
\hline & $\begin{array}{l}\text { Settlement } \\
\text { rehabilitation } \\
\text { for improved } \\
\text { land tenure } \\
\text { security }\end{array}$ & $\begin{array}{l}\text { Do you agree if } \\
\text { the government } \\
\text { has a plan to } \\
\text { develop this } \\
\text { settlement for } \\
\text { you? }\end{array}$ & 13.3 & 31.1 & 33.3 & 11.1 & 11.1 & 45 \\
\hline $\begin{array}{l}\text { Land rights } \\
\text { enforcement }\end{array}$ & $\begin{array}{l}\text { Integrated } \\
\text { relocation and } \\
\text { compensation } \\
\text { policy }\end{array}$ & $\begin{array}{l}\text { Do you agree if } \\
\text { relocation is } \\
\text { accompanied by } \\
\text { compensation? }\end{array}$ & 2.4 & 19.0 & 7.1 & 38.0 & 33.3 & 42 \\
\hline $\begin{array}{l}\text { Tool for land } \\
\text { rights }\end{array}$ & $\begin{array}{l}\text { Grant of } \\
\text { tenure on } \\
\text { long term } \\
\text { occupancy }\end{array}$ & $\begin{array}{l}\text { Do you agree if } \\
\text { long time } \\
\text { occupancy is an } \\
\text { evidence to prove } \\
\text { your existence? }\end{array}$ & 44.7 & 39.5 & 10.5 & 2.6 & 5.3 & 38 \\
\hline $\begin{array}{l}\text { Transparency } \\
\text { in land use } \\
\text { control }\end{array}$ & $\begin{array}{l}\text { Attention to } \\
\text { public input } \\
\text { concerning } \\
\text { land use } \\
\text { planning }\end{array}$ & $\begin{array}{l}\text { Do you agree if } \\
\text { the government } \\
\text { should give } \\
\text { attention to your } \\
\text { opinion } \\
\text { concerning to } \\
\text { your land? }\end{array}$ & 19.5 & 56.0 & 17.1 & 7.3 & 0 & 41 \\
\hline $\begin{array}{l}\text { Equity in } \\
\text { decision } \\
\text { making }\end{array}$ & $\begin{array}{l}\text { Participatory } \\
\text { urban } \\
\text { planning }\end{array}$ & $\begin{array}{l}\text { Do you agree that } \\
\text { if the government } \\
\text { makes a decision } \\
\text { on your land } \\
\text { without } \\
\text { community } \\
\text { participation, it } \\
\text { will be success? }\end{array}$ & 4.4 & 2.2 & 6.7 & 26.7 & 60 & 45 \\
\hline
\end{tabular}

Source: (Wijaya, 2014) and author in field visit in September/ October 2013

*The Bansighat settlement was not affected by the earthquake that occurred on $25^{\text {th }}$ April and $12^{\text {th }}$ May 2015, though it is situated in the effected district (Kathmandu District) 
The SWOT analysis approach is applied to develop the intervention strategies. Internal environmental analysis is done on the strengths and weaknesses of the existing actions of government. An external analysis is made of the opportunities and threats by using elements and criteria as shown in Table 1 and by considering the settlers' views as shown in Table 4. Finally, based on the SWOT factors as shown in Table 5, six intervention strategies are derived (see Table 6), following the principle of maximizing strengths and opportunities, transforming weakness to strengths, and minimizing threats (Yuan, 2013).

\section{Internal environmental analysis}

Our interviews' with governmental agencies suggest three main activities as strengths for resolving conflicts and three issues as weaknesses for handling informal settlement in Bansighat. As tabulated in Table 5 a, these are discussed below:

\section{i) Strengths}

a) Formulating a draft land policy and implementation of land use policy

The national land policy is being drafted whereas the land use policy is already in the implementation phase. The interviews with government and nongovernment officials reveal that issues of informal settlements should be addressed at policy level. The settlers of Bansighat shifted their houses away from the river bank in accordance with the municipal norms of land use restriction along the river bank. So, this shows that land use regulation and restriction can be an important instrument to control informal settlements.

b) Constructing low cost apartments by acquiring land via land readjustment

There is an initiative taken by government to construct low cost housing to relocate informal settlers. About $4040 \mathrm{~m} 2$ land has been allocated by DUDBC to relocate approximately 200 families with own financial contribution and subsidies. The land is allocated from the land readjustment project (Joshi, 2014).

c) Initiating an integrated land development plan

Government has initiated an integrated land redevelopment plan to protect the Bagmati river and its tributaries by constructing an access road, sewer pipe lines, waste water treatment plants and a green belt along the river bank. The project is a joint effort by National Trust for Nature Conservation (NTNC) and the High Powered Committee for Integrated Development of the Bagmati Civilization (HPCIDBC). 


\section{ii) Weaknesses}

a) Failure to resettle informal settlements

The action of government to clear invaded land along the river bank with a resettlement approach did not succeed. There was lack of legal instruments to tackle issues of informal settlements as well as absence of a mechanism to involve civil society groups. This failure to resettle the evicted settlers has given the negative influence on existing settlements regarding the resettlement process and tenure security (Shrestha et al., 2014a).

b) Tolerance attitude of the government towards informal land encroachment

The Bansighat settlement has existed for more than two decades. The land invasion in this settlement increased about 21 times between 1992 and 2013 (Wijaya, 2014). This shows lack of responsibility by the local authorities for not timely implementing restrictions on land invasion, and showing a tolerant attitude. This attitude resulted in maturity of the settlement leading to social recognition instead of legal recognition.

c) Lack of an appropriate tool to identify real informal settlers

The set criteria to qualify for informal settlers from the government perspective itself are not achievable. Furthermore, despite the needs of real informal settlers, there is a tendency of occupying land by elite groups for their own benefits. The government is facing challenges to identify the real beneficiaries of the regularizing program. There is no appropriate tool to record details and authentic information of the settlers. 
Table 5: SWOT Analysis

\begin{tabular}{|c|c|c|c|}
\hline $\begin{array}{l}\text { Internal } \\
\text { environment }\end{array}$ & & $\begin{array}{l}\text { External } \\
\text { environment }\end{array}$ & \\
\hline Strengths & & Opportunities & \\
\hline S1 & $\begin{array}{l}\text { Formulating a draft land } \\
\text { policy and implementation } \\
\text { of land use policy }\end{array}$ & $\mathrm{O} 1$ & $\begin{array}{l}\text { Informal settlers' } \\
\text { emphasis in participatory } \\
\text { planning }\end{array}$ \\
\hline $\mathrm{S} 2$ & $\begin{array}{l}\text { constructing low cost } \\
\text { apartments acquiring land } \\
\text { via land readjustment }\end{array}$ & $\mathrm{O} 2$ & $\begin{array}{l}\text { Informal settlers' } \\
\text { willingness to accept land } \\
\text { use rights }\end{array}$ \\
\hline S3 & $\begin{array}{l}\text { Initiating integrated land } \\
\text { development plan }\end{array}$ & $\mathrm{O} 3$ & $\begin{array}{l}\text { Informal settlers' } \\
\text { willingness to support } \\
\text { government plan }\end{array}$ \\
\hline Weaknesses & & Threats & \\
\hline W1 & $\begin{array}{l}\text { Failure to resettle informal } \\
\text { settlement }\end{array}$ & $\mathrm{T} 1$ & $\begin{array}{l}\text { Informal settlers' } \\
\text { unwillingness towards } \\
\text { relocation and } \\
\text { compensation policy }\end{array}$ \\
\hline W2 & $\begin{array}{l}\text { Tolerance attitude of } \\
\text { government towards } \\
\text { informal land } \\
\text { encroachment }\end{array}$ & $\mathrm{T} 2$ & $\begin{array}{l}\text { Informal settlers' demand } \\
\text { for recognition of their } \\
\text { land rights by titling }\end{array}$ \\
\hline W3 & $\begin{array}{l}\text { Lack of appropriate tool to } \\
\text { identify real informal } \\
\text { settlers }\end{array}$ & T3 & $\begin{array}{l}\text { Informal settlers' demand } \\
\text { for long term occupancy as } \\
\text { a land rights tool }\end{array}$ \\
\hline
\end{tabular}

\section{External environment analysis}

The settlers' preferences on urban land governance elements and indicators, which are based on five Likert scale as shown in Table 4, are incorporated to derive three factors as opportunities and three factors as threats.

iii) Opportunities

a) Informal settlers' emphasis in participatory planning

In the response to the indicator "participatory urban planning", most of the settlers $(60 \%)$ reveal that it is important to have participatory decision making regarding the occupied land. The interviews with civil society organizations also mentioned that it is important to consider settlers' requirements to develop acceptable interventions. The willingness of settlers to join in participatory planning can be translated into an opportunity.

b) Informal settlers' willingness to accept land use rights

More than $50 \%$ of the settlers show positive responses towards the indicator "grant of land use rights". Though, the preference of settlers is for land titles, it reveals that alternative mechanisms for land rights that can provide legal tenure security for incorporating the settlement into the legal framework can be acceptable. 
c) Informal settlers' willingness to support government plan

The majority of the settlers are neutral towards the indicator "settlement rehabilitation for improved land tenure security" for the occupied land. The settlers mentioned that they do not oppose the development plan for the country. However, the development plan should not have a negative impact on their livelihood. Therefore, the settlers' support can be translated into acquiring the occupied land for land development, taking the livelihood aspect into consideration.

\section{iv) Threats}

a) Informal settlers' unwillingness towards relocation and compensation policy

The majority of settlers are not willing to be relocated even when it is accomplished with a compensation policy as more than $60 \%$ of settlers disagree towards the indicator "integrated relocation and compensation policy". The past failure of the government resettlement approach (Shrestha et al., 2014a) has resulted in low trust towards government actions. This is a threat for any government intervention to bring the informal settlement into the legal framework by relocation.

b) Informal settlers' demand for recognition of their land rights by titling

The settlers basically demand title registration of the occupied land. Approximately $60 \%$ of the settlers strongly agree to the indicator "recognition of settlement" by title registration whereas $12.8 \%$ of the settlers strongly disagree as they are aware that land titling is not a possible intervention that the government adopts for the settlements in the urban area. However, settlers' demand for land titles seems a threat.

c) Informal settlers' demand for long term occupancy as a land rights tool

There is no policy to recognize "adverse possession" as such. However, there is a belief among settlers that the government cannot evict those who have stayed for long period. More than $80 \%$ of settlers' agree ( $44.7 \%$ strongly agree and $39.5 \%$ agree) to the indicator "grant of tenure on long term occupancy" mentioning that long term occupancy should be a criterion to recognize their land rights. 


\section{Intervention Strategies}

Based on the above SWOT analysis, six main strategies are identified and shown in Table 6, each intervention strategy is explained below:

a) Address issue of informal settlement in land policy and land use policy

To address the issue of informal settlement in land policy, it seems an important intervention strategy to maximize $\mathrm{S} 1$ and translate $(\mathrm{O} 1, \mathrm{O} 2)$ to strengths. The existing draft land policy should address access to and allocation of land to low income groups and how to deliver land rights to informal settlers. The mechanism to recognize various types of land rights, such as lease, rent, and use rather than land title, can be a viable approach to incorporate informal settlers into the legal framework. Similarly, participatory land use planning and its implementation seem to be an appropriate intervention.

Table 6: Intervention Strategies

\begin{tabular}{llll}
\hline $\begin{array}{l}\text { SWOT } \\
\text { Factors }\end{array}$ & SO Strategies & SWOT Factors & WO Strategies \\
\hline S1, O1, O2 & $\begin{array}{l}\text { Address issue of informal } \\
\text { settlements in land O3 W3, O1, } \\
\text { policy }\end{array}$ & $\begin{array}{l}\text { Interaction of } \\
\text { government, civil } \\
\text { society and informal } \\
\text { settlers }\end{array}$ \\
$\begin{array}{l}\text { Provide low cost housing } \\
\text { with housing subsidy on } \\
\text { relocation site }\end{array}$ & SWOT Factors & WT Strategies \\
\hline SWOT & ST Strategies & W1, W2, T3 & $\begin{array}{l}\text { Enforce land use } \\
\text { against land invasion }\end{array}$ \\
\hline T1, S3 & $\begin{array}{l}\text { Adopt convincing } \\
\text { method to secure land } \\
\text { tenure }\end{array}$ & W3, T2, T3 & $\begin{array}{l}\text { Adopt an approach to } \\
\text { record occupied land }\end{array}$ \\
\hline
\end{tabular}

b) Provide low cost housing with housing subsidy on relocation site

To provide low cost housing with the mechanism of housing subsidy on a relocation site is a strength (S2) which can be maximized by incorporating opportunity 03. It reveals that allocation of land and housing facilities without financial obligations is not acceptable from the government perspective. Moreover, this practice can attract more informal settlers. Therefore, the government strength of acquiring land for low income groups can be translated into pro-poor market interventions such as subsidies and mortgages to afford land and housing in a relocating site. 
While relocating settlements like Bansighat, it is important to understand the financial capacity. The settlers are demotivated in relocation, if their financial burden seems to increase on an alternative site.

c) Interact among government, civil society and informal settlers

This intervention strategy is important to overcome existing weaknesses (W1, W3), incorporating the opportunity $(\mathrm{O} 1, \mathrm{O} 3)$. There is a pressing need for intervention strategies to improve the interaction of urban land governance institutions. The mechanism of collaboration among government organizations themselves and also with civil society is essential to overcome conflicting interests. The clear mechanism to interact with local actors can support the government in identifying real beneficiaries translating the settlers' willingness to a participatory approach to overcome the weakness to minimize the gap. Similarly, the moderate willingness shown by settlers to support the development plan can be strengthened into an effective outcome when social norms and values that exist in settlements are integrated into the formal rules and regulations of the development plan.

d) Adopt a convincing method to secure land tenure

The intervention strategy aimed at convincing the settlers to relocate to safer sites can overcome threat ( $\mathrm{T} 1$ ) and maximizing strength (S3).To do so, settlers need to get land tenure security in terms of legal and social recognition. The availability of infrastructure facilities such as utilities services, access roads, schools, hospitals, and a local market incorporating an income generating mechanism in the resettlement site can be a convincing strategy. Without a source of economic livelihood, or better livelihood opportunity, the settlers cannot stay in the relocation site. Therefore, strategies to create jobs and other economic activities need to be developed.

e) Enforce land use against land invasion

Enforcement of land use regulations and land use restrictions can be the intervention to overcome weaknesses (W1, W2) and to minimize threat (T3). The use of land along the river bank for example for the construction of a road or a park can restrict informal encroachment. The land use instruments can be tools for the responsible authorities to prevent a land invasion. It prevents long term occupancy and social recognition of the settlement.

f) Adopt an approach to record occupied land

One of the biggest challenges facing the government is how to identify genuine settlers. This applies to the Bansighat case as well. The intervention strategies 
to record occupied land and settlers' information involving civil society's role can minimize threats $(T 2, T 3)$ and transform weakness (W3). The mechanism to translate local information (such as occupancy periods, land access) into the legal framework should be on an incremental basis. Incremental approaches such as adopting other forms of land rights like occupation rights and use rights can be an effective approach.

\subsection{Discussion}

\section{The "action space" of Government and Civil Society towards Legitimacy}

The case study showed that there is a lack of explicit policy and policy instruments to regularize informal settlements. As highlighted by Candan and Kolluoğlu (2008), due to the lack of a policy, the government within "action space" limits its recognition of the existing settlements. As such the settlements are not legally visible in any form in the government data bases. In this situation, the political cadre and civil society tend to pull the "action space" towards their action plans. The political cadre created space in the form of a commission to fulfil the political commitment of distributing land to informal settlers. The commitment is usually done to attract votes during time of elections.

The politically appointed commission has been delegated with the power to distribute government land to informal settlers. The process follows the identification of beneficiaries within set criteria of the government, which is, a beneficiary should not have land registered in his/ her name as well as family members' name within the whole country. It was revealed in the case study that sufficient information to verify these criteria was difficult to obtain. It seems that there is "action space" for elite groups to prove themselves as beneficiaries. The criteria set by the government for identifying beneficiaries do not seem to incorporate social norms and values. Referring to Foxon et al. (2009), the civil disobedience towards the action of the government leads to a pull of "action space" towards the logic of civil society. Therefore, there is pressure from civil society on government to redefine the criteria for beneficiaries at policy level.

The results showed a lack of effective policy implementation in providing land and housing for low-income groups. As a result there is a trend of renting as well as buying and selling of occupied land to low income groups within the settlements on the one hand, whereas on the other hand the local authority seems to tolerate the settlements, which have stemmed from the existence of the settlement for more than a decade. As described by Aguilar and Santos (2011), this result indicates that lack of "action space" of the government to provide low-income land for housing results in a tolerant attitude as well as in 
informal settlers themselves pulling "action space" by creating an informal mechanism of access to low income land and housing. In fact, the tolerant attitude of government contributes social legitimacy (Earle, 2014). It somehow reflects that due to the gap at policy level between the legal as well as social norms to handle the issue of informal settlements, the "action space" of government actors is somehow dominated by civil society. Hence, despite the lack of legal legitimacy the "action space" of government as well as civil society is triggering social legitimacy.

The results showed that although the settlers do not have legal documents of the occupied land, the settlers do have perceived tenure security as well as de facto tenure security as highlighted in (Van Gelder, 2010b). The "action space" of the 11th SPRC in the form of a mandate to provide identity cards to beneficiaries, has developed perceived land rights, even though there is no "action space" for this commission to distribute land for identified beneficiaries. The perceived land rights ultimately trigger social legitimacy (Palmer et al., 2009). Furthermore, the formal residents in the vicinity of the case study area tend to stigmatize informal settlements but it was not revealed that there is hard core protest for clearance of the informal settlement by the formal settlers. In fact, informal settlers have de facto tenure security which is the outcome of long term occupancy, upgrading in the settlement and cohesion of community (Palmer et al., 2009). This de facto tenure security further leads to social integration of the informal settlement into the formal settlement. The results showed that settlers have access to electricity. Legally, proof by a legal document of land is required for a connection to utility services. But international conventions like the Human Rights Declaration and also the National Constitution as well as Local Governance Act direct towards provision of basic services as a right of every citizen. The results showed that the identity card issued by the squatter federation is part of the process of recommending the informal settlers for electricity connection. The tacit recognition of this informal document by government contributes to social legitimacy (Nkurunziza, 2008). The development funding from national and international agencies also requires some sort of tenure security. Although, it did not show in the case study area, there seems to be a practice of acquiring documents from local government mentioning that the settlers will not be evicted without provision of an alternative site. In this regard, though, the development plan is not accepted from a legal point of view, but, it is socially accepted within the framework of international norms.

\section{Intervention Strategies to Minimize the Gap between Legal Legitimacy and Social Legitimacy}

The improvement in urban land governance institutions seems an important intervention strategy to minimize the gap. There is a need for cooperation between the government and civil society regarding the interventions relating 
to access to, and use of informally occupied land. The interaction between government and civil society is a crucial determinant for the success of any intervention (Krueckeberg and Paulsen, 2002). The lack of an effective mechanism of interaction and coordination between the government and civil society has resulted in the failure of government actions to regularize and resettle (Author, 2014). Therefore, for effective service delivery at local level, the "action space" of civil society and community leaders needs to be identified (Harpham and Boateng, 1997).

\section{i) Formulate a policy to recognize existing informal settlement}

The case study showed that absence of proper legal instruments and an unclear legal mandate restrict the government in taking timely action towards land invasions. The lack of immediate action leads to settlements getting mature, upgrading their shacks into concrete houses, developing community bonding which all contribute to social acceptance (Shrestha, 2013), in fact contributes to social legitimacy. The results reveal that the issue of informal settlements needs to be addressed in the land policy. The policy review of various countries by Van der Molen et al. (2008) reflects recognition of informal settlements in land policies, which determine the forms of land rights and the level of tenure security to be allowed to informal settlers. Furthermore, policy instruments need a persuasive mechanism in case the settlements need to be relocated. The persuasive mechanism could be a provision of social and physical infrastructure at affordable costs, appropriate financial subsidies on the relocation site, adaptation of affordable building regulations, and an incremental approach to upgrading. One of the critical problems for the relevant authorities regarding informal settlement is the criterion to identify appropriate beneficiaries for any regularizing and relocating project to exclude elite groups who are searching for an opportunity to legalize informally occupied land. The norms set by the government are not acceptable to informal settlers. Therefore, an inclusive criterion for recognition of land rights of genuine settlers is important in order to minimize the gap between legal legitimacy and social legitimacy. Furthermore, those fake settlers who are rich enough to purchase land on their own but still live on government or public land without legal documents should be identified and forced to leave (Shrestha, 2013; Tanaka, 2009). Their existence causes a negative impression towards the authorities. In this regard, the incorporation of approaches like pro-poor land recordation (Zevenbergen et al., 2013) at the policy level seems important while recognizing and enforcing land rights of informal settlers.

Furthermore, the policy should recognize various types of land rights besides free hold title. The possibility to recognize informal settlers via providing them with various types of land rights fits well within the framework of approaches like the continuum of land rights (UN-HABITAT and GLTN, 2008). 
ii) Provide land tenure security from legal, social and economic perspective

Informal settlements located on the river bank are prone to disasters which affect the social well-being; nevertheless, settlers are reluctant towards relocation. The case study showed that intervention strategies aimed at convincing informal settlers to be relocated to safer sites with guaranteed secure land tenure is important. The study of Patel (2013) shows that the level of tenure security of informal settlers is connected to the social and economic structure of the settlement. Furthermore, Krueckeberg and Paulsen (2002) highlighted that the selection of sites far away from an existing settlement affects social and economic structure, leading to unsustainable relocation plans as there is ample evidence of vacant relocation sites. Hence, an integrated relocation approach considering the settlers' social as well as economic needs seems important. The application of tools like STDM to collect various types of social tenures that exist in informal settlements is important prior to providing legal recognition (Augustinus et al., 2006)2006. Despite the tenure security from a social and economic perspective, legal tenure security by providing free hold title to informal settlements does not prove to be an effective intervention to formalize informal settlements though the settlers basically demand a free hold title. Moreover, interventions to provide land and housing without financial obligations seem to attract elite groups which are mentioned in the study of Shrestha (2013) as well. Therefore, intervention in the market from the perspective of secure tenure for low income groups seems viable. In the meantime, legal shortcomings to allow recognition of settlements by providing various types of land rights need to be overcome. Therefore, interventions to bring informal settlements into the formal setting based on the concept of the continuum of land rights can be an appropriate measure. It aims at protecting the tenure security for the majority of people, including the poor from a broader perspective on tenure security (UN-HABITAT and GLTN, 2008).

iii) Land development of informal settlement from the perspective of land tenure security

The land use regulations and restrictions for land development are an identified intervention strategy from the case study results to discourage land invasion. Although the settlements are along the river bank, incremental development and upgrading of the settlement is happening. The "action space" of the local government, non-government organizations as well as settlers themselves allows for the provision of utility services and physical development. This is found to contribute to the social legitimacy and to the reluctance towards resettlement when settlements are upgraded. Settlements which are not feasible to persist from the perspective of environmental degradation should not be allowed to mature. Immediate action from the relevance authorities should be taken, restricting the informal occupancy and controlling land 
invasion in environmentally sensitive zones. As highlighted by Augustinus (2010), besides a reactive approach it is necessary to adopt a proactive approach to control informal land development.

Similarly, case study findings showed the persuasive approach with tenure security while upgrading as well as relocating to alternative safer sites seems important as a part of an integrated package of land development. When this is done, a donor driven project with an approach of relocation with minimal infrastructure in alternative location is critically opposed by (Huchzermeyer, 2002 ; 2003). He mentions that providing one-time capital subsidy to build a house in an alternative location is not a viable solution for informal settlements. The rigid standardization in building norms and plot sizes makes settlers insecure from an economic perspective. On the other hand, provision of infrastructure (water supply, drainage, and road) through a private developer increases the cost for the relocation plan as well as for upgrading. Land development needs to be carried out in a participatory way involving community members. This strategy leads communities to focus on development priorities, objectives and approaches within the financial capacity of the settlers. The provision of an integrated local technical expertise and tacit knowledge within the legal framework creates "action space" for the community which can bring effectiveness in service delivery (Harpham and Boateng, 1997). The provision of land and housing subsidies and low cost land for housing can be part of intervention strategies to relocate existing settlements as well as to prevent growth of informal settlements. According to Huchzermeyer (2002), the subsidies should be at the community level rather than for individual households.

\subsection{Conclusion}

This paper reflects on how the "action space" of the government and civil society creates the gap between legal legitimacy and social legitimacy, and presents intervention strategies that minimize the gap on legitimacy. The empirical evidence highlighted that "action space" of NGOs, civil society and local government is directed towards social legitimacy, while the government "action space" directed towards legal legitimacy is less significant. While considering the "action space" of civil society, it points towards the social network created through the settlers' federations that have lent credibility to the social legitimacy of informal settlements. Similarly, the tolerance attitude from the government as well as formal settlers in the vicinity of informal settlements is another factor pointing towards social legitimacy. However, the lack of appropriate legal instruments on the one hand, and the increasing social recognition due to "action space" of government as well as civil society accelerating the social legitimacy on the other hand, has clearly created the gap. Hence, the challenge in urban land governance lies in tackling the land 
and housing issue of informal settlements by minimizing the gap between social legitimacy and legal legitimacy. In this context, this paper has further explored the intervention strategies to minimize the gap within the scope of policies, land tenure security and land development.

The land policy should address informal settlement by formulating a regularization policy taking social norms and values of informal settlements into account. On the other hand, a policy intervention to control the growth of informal settlements is equally important. To implement policy interventions like upgrading and relocation, "action space" for local authority, civil society and NGOs needs to be clearly defined. Also, a broader conceptualization of "tenure security" of informal settlements is important. The intervention strategies in land tenure security should incorporate an approach like the continuum of land rights instead of adopting land titling, since that approach has not shown to be an effective and efficient measure to handle the existing issue of informal settlements. The concept of pro-poor land recordation and the STDM should be implemented during the process of regularizing informal settlements to prevent elite beneficiaries to benefit from the state intervention. Instruments like land use regulations are important to restrict land development and provision of social as well as physical infrastructure in land not suitable for inhabitants. Similarly, intervention strategies in land development need to consider the limits in market acceptance of low-income groups. This somehow concludes that interventions in the formal land and housing market are important to address the issue of informal settlements from the perspective of a proactive approach to restrict growth in informal settlements as well as a reactive approach to minimize the gap between legal legitimacy and social legitimacy.

This study focused mainly on two types of actors, government and civil society. The intervention strategies require recognition of the role and synergic collaboration of all actors (government, civil society, market) in urban land and housing development. Presently, it is clear that neither the private nor the public sector alone can tackle the issue of informal settlers. Since this research does not include the role of market actors and their interaction with other actors in the applied analytical framework, further research adding the market perspective in urban land governance for informal settlements is recommended. 


\section{Chapter 3: "Action space" in Land Readjustment: Urban Land Governance, Low- Income Housing Issues of Informal Settlers in Nepal ${ }^{6}$}

6 This chapter is based on the paper submitted to Land Journal

Shrestha, R., Zevenbergen, J., Banskota, M., \& Masum, F. (2019). "Action space" in Land Readjustment: Urban Land Governance, Low-Income Housing Issues of Informal Settlers in Nepal. Land. 
Abstract: Understanding urban land governance pattern in providing access to land for low-income housing is important. The lack of access to such land has hindered in addressing inclusive development and preventing the displacement of low-income groups. This paper analyzes urban land governance pattern between government and market actors, with respect to participation and inclusiveness. The concept of "action space" is adopted as an analytical framework, in which 'regulatory compliance' and 'regulatory noncompliance' are conceptualized to understand the governance pattern. This approach is then applied to Icchangu Land Readjustment (LR) project in Kathmandu, Nepal. Results demonstrate that the current land governance pattern in the LR approach is unable to capture the value for low-income housing. However, the project is successful in capturing the value for infrastructure development as it increased land price within the project area. The paper concludes by discussing the applicability of the action space based LR framework to analyze governance patterns and identify the factors that hinder the potential of LR in allocating land for low-income housing for inclusive development. Further, the recommendation is given to include civil society actors such as low-income groups to analyze the governance pattern in LR.

Keywords: "Action Space"; Land for Low Income Housing; Land Readjustment; Inclusive development 


\subsection{Introduction}

Weak urban land governance causes difficulties in the provision of land for lowincome housing to accommodate low-income groups. Eventually, this leads to eviction and displacement of the groups without appropriate or no access to shelter. The nomenclature, urban land governance, in this study, stands for the policies and processes (Deininger et al., 2010a) that influence the actions of the key actors, namely the government, market and civil society in their decision to provide access to and allocation of land for low-income housing (Deininger et al., 2010a). In urban land governance, the lack of balanced action between key actors can influence the expected outcome, which is to say that the dominance of one of these key actors during a set period of action generates a specific pattern of governance (e.g. government-led governance, market-led governance or civil- society led governance)(Foxon, 2013). Blessing (2012), has demonstrated that lack of balanced action between the government and the market -has affected the production of low-income housing- due to state and market dualism. Various other studies have emphasized the necessity of understanding both - the blended action, and logic of government and market actors - in order to overcome the weakness in urban land governance in general (Azzari et al., 2018) and the provision of low-income housing in particular (Blessing, 2012; Czischke et al., 2012).

To investigate the governance pattern in allocating land for low-income housing, this paper draws on the concept of 'action space'. This concept has been applied by various scholars in understanding governance patterns between government and civil society actors through the analysis of the gap between legal legitimacy and social legitimacy in the case of informal settlements (Shrestha et al., 2016b). The concept has also been applied between market actors and civil society actors in the resettlement of informal settlements to provide low-income housing (Shrestha et al., 2018). For the present study, the notion of regulatory compliance and regulatory noncompliance are conceptualized as in Shrestha et al. (2016b) in order to understand the interaction between government and market actors. The notions are instrumental in analyzing the push and pull that occur within the action space between government and market actors, with a legitimacy ${ }^{7}$ (Suchman, 1995) of their actions in land development for low-income housing.

Land development has been approached through several methods such as land sharing (Rabé, 2010), guided land development (GLD) (Marulanda \& Steinberg, 1991), incremental housing and settlement upgrading (Greene \& Rojas, 2008), site and services (Chhetri, 2014), and land readjustment (LR)

7 'a generalized perception or the assumption that the actions of an entity are desirable, proper, or appropriate within some constructed systems of norms and values,' 
(Hong \& Needham, 2007). This study examines the action space concept within the land readjustment (LR) approach. In this approach, landowners contribute land for development, and government as well as market actors are involved (Hong et al., 2007). The consensus amongst these actors is an important condition for successful implementation of LR (Sorensen, 2000). Owing to the popularity of LR for land development, a number of scholars have put the approach to wide range of applications (Chhetri, 2014), including urban regeneration (Li \& Li, 2007; Turk \& Korthals Altes, 2010b), urban development (Mittal, 2014; Uzun, 2009), post-disaster (Mukherji, 2014), and the regularization of informal settlements (Supriatna \& van der Molen, 2014; Uzun et al., 2010). The very scope of its applicability makes LR a suitable case for the present analysis from the governance perspective. The paragraph below examines good practices in LR through the review of relevant literature.

A survey of literature on urban land governance and the allocation of land for low-income housing through LR reveals a need for additional studies. Yilmaz et al. (2015), for instance, call for further study to evaluate applicability of LR to the contexts where legal tenure is unclear. Others have indicated the potential of LR in the allocation of some portions of developed land to accommodate low-income groups (Sandhu, 2004; Turk, 2014; Turk \& Korthals Altes, 2014). Although the conventional LR approach has the potential to yield inclusive outcome (i.e. the accommodation of low-income groups), a study on LR practices in Turkey, Turk (2014) indicates the scope of reform in institutional and legal domain. This finding appears consistent with those concerning LR practices in other countries as well. Hong and Julia (2013) add a different approach to the LR literature by framing conventional LR within Participatory and Inclusive Land Readjustment (PILaR), the approach introduced by UN-Habitat and the Global Land Tool Network (GLTN) to promote participation of all the affected groups in the LR process so as to achieve inclusiveness in its outcomes.

Given that the available studies point to the need for further comprehensive studies, this study examines the interaction between government and market actors by applying concept of "action space" in allocating land for low-income housing. Taking into account two governance principles that are considered pertinent in LR in Nepal, - participation and inclusiveness -, potential strengths of LR in allocating land for low-income housing are analyzed.

The following sub-sections, describe theoretical background rooted in the practice of land readjustment for low-income housing, present the conceptual framework of action space for the context of $L R$, describe methodology, describe a case study results involving $L R$, discusses the action space and the market legitimacy of $L R$, and draws conclusion. 


\subsection{Land Readjustment practice for allocating land for low-income housing}

Land Readjustment is regarded as land development tool to promote the use of land for residential purposes by readjusting fragmented land ownership (Lin, 2005). It is a self-financing land development tool (Larsson, 1997; Mittal, 2014). The LR process consists of converting irregular parcels into well-planned regular parcels and reallocating them to the original landowners after deducting a certain percentage of land area, possibly with an increase in the market value of the land (Archer, 1992; Shrestha et al., 2017a; Yau, 2012). This process reduces the financial burden on the government to provide public facilities through the value capture from the land contributed by landowners (Lin, 2005). Land value capture, that is the enhanced value of the land resulting from infrastructure development, is the primary instrument that facilitates public authority for the provision of public infrastructure and social facilities (Calamia \& Mauach, 2009; Muñoz-Gielen, 2014).

\section{The potential of $L R$ in providing land for low-income housing}

The application of LR is quite broad despite the fact that it is less commonly used to address the housing needs of low-income groups. As observed in the studies of Ahmet and Hulya (2015) and Sandhu (2004), LR has potential to allocate a certain percentage of developed land for low-income housing if the LR process is executed with standard procedure. The implementation of LR processes for low-income plots is nevertheless difficult without government intervention because the market value of the land increases with the success of LR project (Shrestha et al., 2017a) . As highlighted by Needham (2004), various constraints affect the land provision for the low-income housing, including unaffordable land prices under formal market conditions, lower profits in the low-income housing sector, and potential diminishing on the value of land near low-income housing. To overcome this constraint, according to Paris (2007), it is important to replace the tendency to use non market forms of providing low-income plots ( government as a provider of low-income housing) by market forms of provision (government as a facilitator to the market). In the market forms, government can apply various fiscal instruments to regulate market actors' action. These fiscal instruments include tax and VAT incentives, betterment levies, development gains, subsidized loans for developer of low-income housing, provision of land for low-income housing at below market value or free of cost (De Kam, 1998; Holmans et al., 2002). Similarly, the study conducted by Shrestha et al. (2017a) foreground the necessity to give attention to the norms of market actors in LR process so that potential of LR for allocating land for low-income housing can be implemented. 
That said, it becomes imperative to see through governance perspective, considering the interaction between government actors and market actors, to capture the potential of LR process in allocating low-income plot.

\subsection{Conceptualizing action space in the LR to low- income plots}

"Action space" is an analytical concept that allows analysis of various governance patterns such as government dominant, market dominant or civil society dominant (Foxon et al., 2009). It must be emphasized that the concept of "action space" has been applied by various authors. Foxon (2013) applied the concept in explaining the pattern of governance amongst actors in the government, the market, and the civil society. Kågström and Richardson (2015) used the concept within the context of environmental impact assessments (EIA) to explain the 'potential', 'actual' and 'interpretative' spaces for action on the part of practitioners. Similarly, the concept has been used to explain the pattern of governance and the legitimacy existing between government and civil society actors (Shrestha et al., 2016b), and between market and civil society actors (Shrestha et al., 2018). In order to analyze the interaction between government and market actors, this paper applied the concept, "action space" (see Figure 7).

Within the concept of "action space", the notions of 'regulatory compliance' and 'regulatory noncompliance' are set as in Shrestha et al. (2016b). These notions are applied to analyze the push and pull that occur within the action space between government and market actors, along with the legitimacy of their actions in LR to allocate low-income plots.

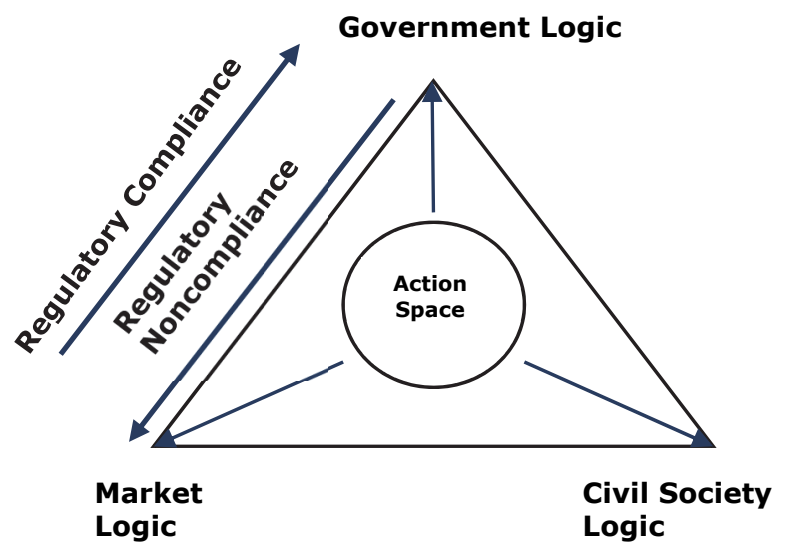

Figure 7: Analytical framework of "Action Space" to analyse interaction between government and market actors

(Adopted from (Foxon et al., 2009), (Shrestha et al., 2016b) and Modified by Authors). 
Regulatory compliance refers to the outcome of the actors' action when it is compliant to the legal regulations. The legal regulations in their common form refer to the use of government authority to prohibit, permit or prescribe private actors' action. Contrarily, regulatory noncompliance means market actors' logic is non-compatible with the government regulations. Such noncompliance with government regulations may stem from the actors' willful avoidance or ignorance of what government regulations require (Potoski \& Prakash, 2005). In fact, the avoidance and ignorance are highly likely to arise when the existing set of regulations are not compatible with the actors' norms and values. For instance, if the regulations are not compatible with the market norms then market actors do not get motivated to comply with the government regulations. Therefore, regulatory compliance is also the process of putting in place the measures necessary to comply with the regulations that are required to achieve the targeted goal(Potoski et al., 2005).

In the cases of regulatory noncompliance, the level playing fields are not created for the market actors. The level playing fields are categorized into two types: rule- based and outcome-based. In the former, the applied rules are same for all firms; whereas in the latter, all firms have the same expected profit despite asymmetric rules (Appelman et al., 2003). In the outcome-based level playing field, rules are applied on equity basis rather the equality. When rules are applied on the equity basis, the regulatory compliance with set regulations is achieved and help is catered to obtain the desired outcome.

In allocating land for low-income housing by the market actors, it is required to apply the rules on the basis of equity. The same rules, in the process of developing land for high income groups with profit motive and for low-income groups, does not create the outcome based level playing field. Thus, noncompliance with the rules that requires setting aside the part of the development for low-income groups by market actors indicates that there is no outcome based level playing field.

In brief, action space is towards government actors for allocating land and housing for low-income groups when there is 'regulatory compliance' whereas action space is towards market actors catering high income groups only where there is 'regulatory noncompliance'.

i) Regulatory compliance within the LR to allocate low- income plots

Examples of good practices in LR reveal two governance principles -participation and inclusiveness, which can be generalized to define action space that is a pull towards the government by providing regulatory compliance to the market actors. 
a) Legal norms for the participation of various government actors, private developers, and land owners

The legal norms that guide the involvement of various government departments, private developers in the LR process, when implemented, lead to the regulatory compliance in the allocation of the low-income plot. The legal norms that make it compulsory for the government and private developers to cover the financial aspects of infrastructure development within LR projects reduces the amount of sales plots needed to cover the cost of the project. The lessened production of sales plots ultimately reduces the land contribution rate of landowners. Further, the availability of financial support from the government and private developers stimulates early development of infrastructure (Mathur, 2013; Turk, 2007). As demonstrated in the practice of LR in Gujrat, India, one essential factor to generate market viability of LR is the early development of infrastructure. In this situation, even after contributing percentage of land and paying a betterment charge the landowners could eventually acquire immediate monetary benefit due to an increase in the value of their land, induced by infrastructure development. As such, the early development of infrastructure subsequently gives market legitimacy to the landowners (Mathur, 2013; Sorensen, 2000). This apparently motivates to allocate a certain percentage of land for low-income plots. Examples of the LR model in Europe indicate that local governments often fund infrastructure costs. In Japan, gasoline taxes are used to fund infrastructure (Mathur, 2013). In any context, when the burden of infrastructure costs is lessened in the LR process, this enables the government to use its valuecapture instruments to allocate low-income plots.

Similarly, the legal norms that give clear guidelines for effective landowners' participation, when enforced, facilitate the government in its efforts to provide the regulatory compliance in the allocation of low-income plots. The lack of clear legal provisions is reported to have hindered the LR process in Turkey (Erdem \& Meshur, 2009; Sorensen, 2000). Understandably, the participation of landowners is important to the smooth implementation of projects in terms of a clear understanding of land-value gain, betterment taxes, landcontribution rates, and land reallocation after land development. The landowners' clear understanding of the LR procedure contributes to the timely completion of the project, which in turn enables value capture for merit goods such as low-income housing, either through the sale of developed plots in the high market value segment or by capturing value via a betterment tax (Squires, 2012). Thus, legal norms enabling landowners to participate in LR process creates a mechanism that supports in convincing the landowners to set aside some of their lands for low-income housing. 
b) Inclusive legal norms for the provision of low-income plots

Inclusive legal norms help in achieving regulatory compliance to provide housing for low-income groups. In general, housing-related studies (Calamia et al., 2009; Mallach, 2010) refer to inclusive legal norms in the form of inclusionary housing $(\mathrm{IH})$, to mean the manner in which the planning instruments is used in the provision of land for low-income housing by capturing profit from the market (Turk et al., 2014). In order to obtain effective implementation of IH norms, planning instruments which provide incentives such as density bonuses and development-fee waivers for allocating a certain percentage of development (Brunick, 2003) are required. As observed by Calamia et al. (2009), IH norms sometimes influence market-driven development in the provision of housing at below-market prices thus achieving the regulatory compliance in the LR process.

The LR case from Turkey illustrates the regulatory compliance in allocating land for low-income housing via applicability of IH norms. The case nevertheless suggests legal reform within the existing legal framework for achieving the regulatory compliance in order to capture low-income groups (Ahmet et al., 2015). Similarly, Gujrat LR practice shows the lack of regulatory compliance: although there are legal norms to capture up to $10 \%$ of all serviced land, less than 3\% has actually been captured (Sanyal \& Deuskar, 2012). In fact, allocation of land for low-income housing in LR projects is accompanied by the risk of decrease in the value of land in the vicinity (Needham \& de Kam, 2004). Therefore, the enforced legal norms to allocate low-income plots do not comply with the market norms of allocating land for low-income housing in the LR process, unless the market instrument is applied to regulate land speculation or freezing land developments, known as factors for market distortion.

ii) Regulatory noncompliance in the LR approach to low-income plots

The section below shows the way to get to a level playing field within the context of equity to the market actors while allocating land for both highincome groups and low-income groups. The created level playing field allows the action space to be pushed towards market actors in the allocation of land for low-income housing.

a) Participation of landowners in allocation of low-income plots

A level playing field is important to ensure participation of landowners in the allocation of low-income plots, given that their participation is based on market legitimacy. For landowners, market legitimacy is generated when there are monetary benefits due to increments in the market value of their land after contributing land for infrastructure and services (Archer, 1992). High level of 
land contribution generate negativity towards projects amongst landowners, thereby affecting project success (Li et al., 2007). The compulsory inclusion of low-income plots for low-income housing by increasing the land contributions of landowners is thus an indication of lack of level playing field.

b) Inclusiveness by equitable access to land

Access to land for people residing outside the LR project area is made possible through formal land markets, in which the plot of land for sale within LR project area is brought onto the land market. In many cases, however, the land that is for sale is not affordable to low-income groups. As highlighted by Supriatna et al. (2014), making such land affordable for low-income groups requires creation of a level playing field by developing a mechanism of providing loans at a low-interest rate to the targeted low-income groups. Alternatively, inclusiveness can be achieved by creating a level playing field for the agencies producing low-income housing. As suggested by De Kam et al (2008), level playing field can be created by bringing low-income housing agencies into the market as landowners, and facilitating their efforts to purchase land at low prices within the LR project area. To facilitate them, incentive mechanism based on the use of various market instruments is required.

Without any market intervention, the free market may not provide a level playing field for low-income housing developers (Bbun \& Thornton, 2013). The imposition of market instrument can create a level playing field for the market actors. According to Brunick (2003), there should be lucrative market incentives (e.g. density bonuses or subsidies for development permit fees) to private developers in order to create a level playing field for them in the provision of low-income housing. In addition, the existence and implementation of favorable policies such as easy access to land are necessary for land and housing developers. A case study from India shows that high land costs and hold out problems combined with the lack of availability of lowincome plots impose major constraints on private developers in the provision of low-income housing (Ram \& Needham, 2016). In brief, giving private developers access to land at below market prices in LR projects can create a level playing field for developing the low-income housing.

\subsection{Methodology}

Single case study approach was applied to this empirical study. According to Yin (2003), the use of a single case is justified if the case represents a unique situation. The selected case, Icchangu Land Readjustment (LR) project in Kathmandu, Nepal, was unique in the sense that it was the only project out of 19 LR projects in Kathmandu Valley in which the government acquired land for low-income housing (Joshi, 2014). 
To collect primary data, semi-structured interviews were conducted with eight government officials. Of them, four were key informants in the LR projects, and four were from the Ministry of Urban Development (MoUD). Additionally, two semi-structured interviews with key informants from the users' committee were conducted. Besides, a structured questionnaire was administered to 20 respondents residing near the low-income housing in the Icchangu (LR) project. The result is presented in Annex 1.The respondents were selected through purposive sampling. Additional interviews were conducted with five experts from land and housing development sector to understand the market imperfections in the allocation of low- income plot and housing in general within a broader context. Secondary sources, mainly legal provisions, were referred after collecting the primary data.

\subsection{Case study Results}

i) Legal provisions for Inclusiveness in land development approaches in Nepal

The inclusionary provision of low-income plots for low-income housing is mentioned in the Urban Policy 2007, the National Shelter Policy (NSP) 2012, and the Town Development Directives (TDD). Particularly, TDD mentions several inclusionary criteria such as minimum $10 \%$ of housing plots in site and services, $10 \%$ of sales plots $^{8}$ in $\mathrm{LR}, 10 \%$ of land developed by private developers for low-income groups (Neupane, 2014; Nisha, 2015). None of the land development approaches, however, seems to have adopted the inclusionary criteria (Neupane, 2014; Nisha, 2015). Until 2014, the total area of land developed for residential housing according to the sites and services was 37.34 ha; the road length developed for access road according to the GLD approach was $324 \mathrm{~km}$; and the total area of land developed for residential housing according to the LR approach was 259 ha (Neupane, 2014)(See Annex 2).

ii) Overview of the Icchangu LR Project

The Icchangu LR project, area of 30.94 ha, located in the Nagarjun Municipality, was initiated in 2006. In November 2015 until April 2016, when the field visit was carried out, the project was still in progress. The project completion date was extended, as the project had been pending for 2.5 years due to landowners' objections on the ground of high land contribution rate. Finally, the average land contribution rate was set at $30 \%$. Within the project area, most land was owned privately, with a minority $(0.12 \%)$ of the area having no formal landownership. There were 1003 plots and 380 landowners before LR; but following the planning, there were 924 plots with more than

${ }^{8}$ Sales plots are also termed as the reserve plots which are reserved from the land contributed by land owners for selling purposed to recover the cost of LR project 
500 landowners (DUDBC \& KVDA, 2005; Nisha, 2015). The minimum size of plots was $80 \mathrm{~m}^{2}$ and maximum size was $1781 \mathrm{~m}^{2}$ (Nisha, 2015; Tiwari, 2016)

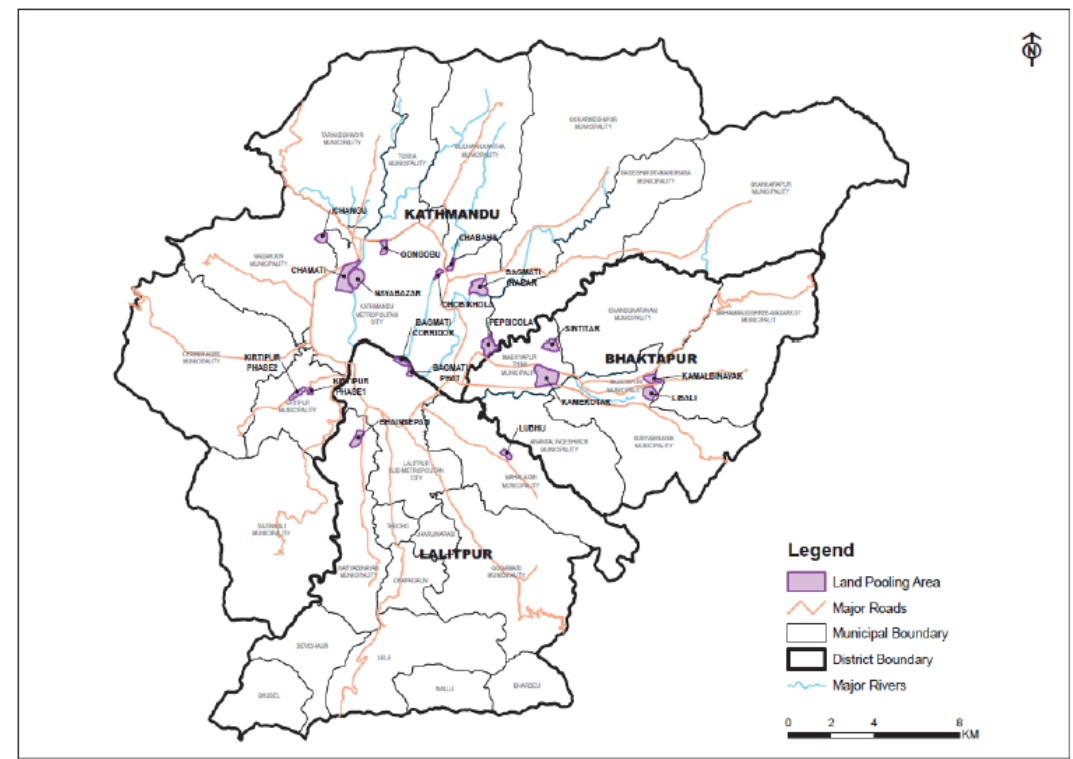

Figure 8: Location Map of Land Readjustment9 Projects in the Kathmandu Valley (Including Location of Icchangu LR project)

(Source: Shrestha et al. (2017b)).

Table 7: The project initiative phase

\begin{tabular}{|c|c|}
\hline $\begin{array}{l}\text { General Time } \\
\text { Line }\end{array}$ & Activities \\
\hline June 172002 & Decision to implement project \\
\hline Sept 172006 & Approval from cabinet decision to start project \\
\hline Sept 42007 & Land acquisition notice from district level office \\
\hline March 102008 & $\begin{array}{l}\text { The court decision to hold on the project due to } \\
\text { objection from land owners }\end{array}$ \\
\hline July 7th 2009 & The court decision to continue the project \\
\hline
\end{tabular}

${ }^{9}$ Termed as Land Pooling in Nepal 


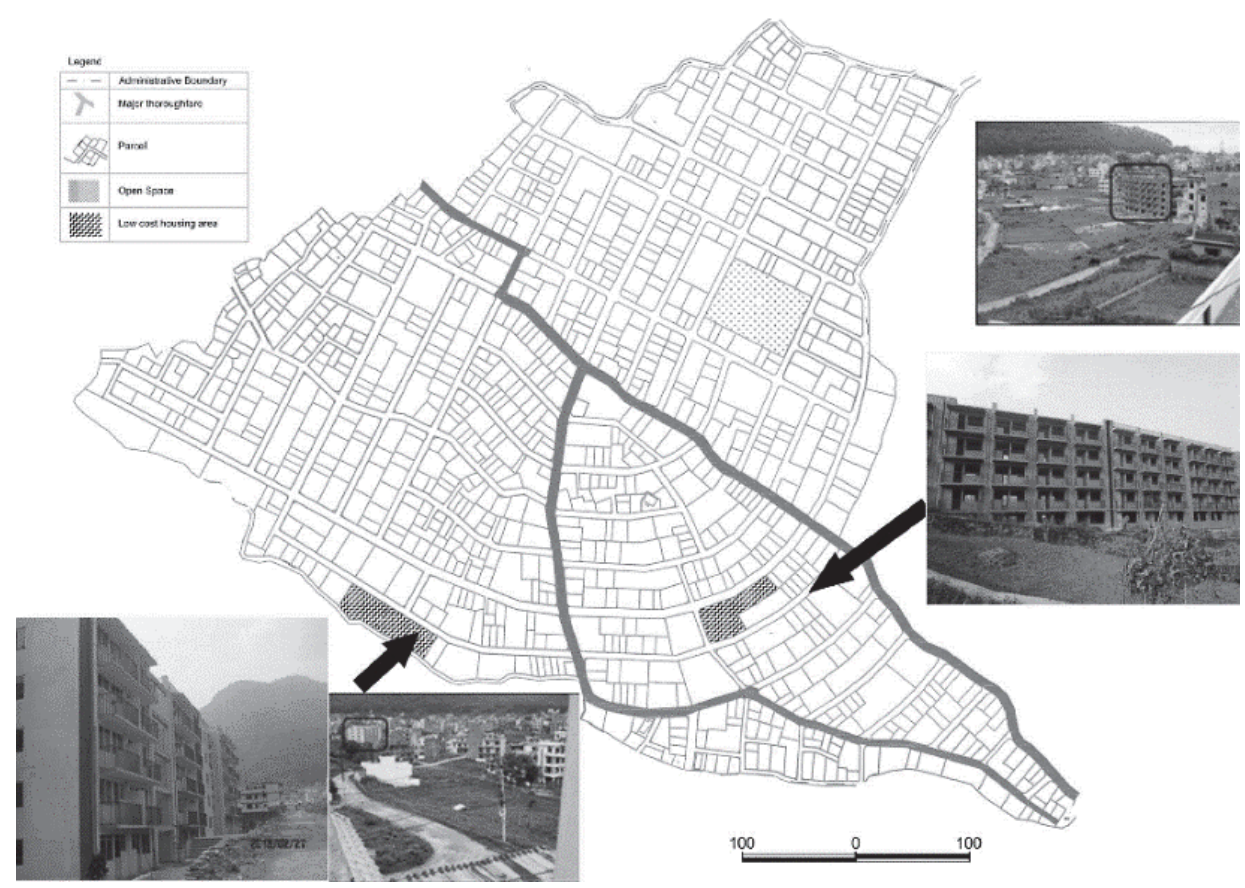

Figure 9: Location of low-income housing in the Icchangu LR project. (Adopted from (Nisha, 2015) and Field observation)

\section{iii) Findings of the Icchangu LR case study}

a) Participatory Approach in the Icchangu LR Project

Icchangu project did not involve any government line agencies and market actors (private developers) in funding the project (Interview: member of the users' committee). All cost of the project was raised through the sale of plots, although the Shelter Policy 2012 does mention cost sharing for infrastructure. Complying with the Policy, private developers were hired only as a contractor for infrastructure development, and a competitive bidding procedure was held.

The institutional framework for the participation of landowners in this case was ensured by forming the users' committee and the management committee. In general, users' committee consists of at least 15 landowners: a director, a secretary, a treasurer and 12 general members, with the director usually being the mayor of the municipality. In this case, however, there were 29 landowners in the committee, although not all of them participated actively (Interview: member of the users' committee). In addition, the director was selected from the landowners themselves, as there was no elected mayor in the municipality when the project commenced. 
In this case, the government actor were involved in the LR process as market actors, given that the Department of Urban Development and Building Construction (DUDBC) purchased a total of 0.40 ha of land to develop housing for resettling informal settlers 10 who had been evicted elsewhere in 2012 [see for detail Shrestha et al. (2014a)]. The users' committee felt obligation to sell sales plots to the Department of Urban Development and Building Construction (DUDBC) because of a financial crisis. The crisis occurred when Nepal Rastra Bank (NRB) amended the real estate financing mechanism. The amount of residential loan against house/land was curtailed by setting the threshold of not exceeding the two-third of fair market value of the collateral (Nepal Rastra Bank, 2011).This ultimately effected land market demand. A decline in the market demand for the sales plots in the project prevented the committee from accumulating the finances needed for infrastructure development.

As informed by a member of Users' committee, 'In the initial phase of the project, the land market was stagnant and there were fewer buyers in the market for the sales plot. When the DUDBC offered to buy a large parcel of land and also agreed to pay $20 \%$ more than the quoted price, the users' committee agreed' (interview: member of the users' committee). The DUDBC

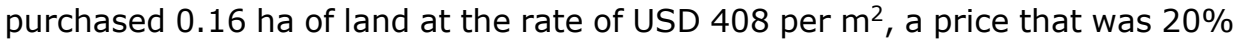
above the minimum land market price of USD 340 per $\mathrm{m}^{2}$ quoted for sales plot in the initial phase. In the second phase, the government purchased 0.23 ha of land at this minimum quoted market price for sales plot In addition the negotiations was done with landowners concerning the provision of the access road to the LR project site (Nisha, 2015). (Refer Annex $V$ for detail calculation of minimum market price in (Nisha, 2015).

The response of the landowner on how they perceived these developments made it clear that there was no explicit participation of all landowners when the land was sold for low-income housing. According to their knowledge, the beneficiaries consisted of informal settlers, individuals affected by the earthquake ${ }^{11}$ and low-income government officials. The respondents stated that, if the beneficiaries of the low-income housing were to be informal settlers, the social environment would be spoiled, causing a negative impact on the value of land in the vicinity. The interviews reflected the social stigma that the respondents attributed to the behavior of the informal settlers, characterizing their living habits as unhygienic and describing them as ill-mannered, drunk or having a criminal background. For these reasons, they did not wish to include informal settlers as the beneficiaries of the low-income housing built within the project area.

\footnotetext{
${ }^{10}$ Informal settlers are low-income individuals who had settled on land without ownership document elsewhere basically in the bank of the river

${ }^{11}$ The devastating earthquakes that occurred in August 2015 and May 2015 in Nepal
} 
As remarked by one respondent, "My son might become spoiled or might get married to the girl of informal settlers, I cannot take the risk."

The results of interviews with a member of the users' committee and with project officials revealed that representatives from the government sector did not take any initiatives to provide information or counsel regarding the purpose of low-income housing. Also, there was no participatory forum for cultivating social integration between the informal settlers and existing residents. The landowners appeared to have been unhappy about the weakness of the government in providing clear information about the beneficiaries.

b) Inclusiveness in the Icchangu LR project

According to the project manager, the project had its own inclusiveness norms focusing on not displacing inhabitants within the project area. For example, as a part of the project, a new house was constructed (see Figure 4) within the project area for one identified informal settler, who was residing there for many years. This situation arose due to the layout plan of road that required demolition of his house. However, it was not possible to give him legal ownership of the constructed house and land as he did not have any legal ownership documents for the previously occupied land. The landowners left with small area after replotting the plan (area less than $80 \mathrm{~m}^{2}$ and depth less than $6 \mathrm{~m}$ as per technical norms provided by Town Development Act 1998) had to either buy an extra land to meet the threshold of $80 \mathrm{~m}^{2}$ or sell their land to the project. Collegially, however, the LR project offered them with land at low price compared to the price paid by the buyers residing outside the project area and thus prevented their displacement.

It was found that the plots within the project area were unaffordable for the low-income groups residing outside the project. The value of the land was observed to increase dramatically. In 2000, the land was valued at around USD 31.45 per m2; But by 2014, it increased to around USD 283 per m2 (Nisha, 2015). This provides evidence of an increasing trend in land value. Karki (2004), reported a similar observation, noting land-value increase from 300\% to $600 \%$ in other LR projects. Interview with the respondents in the project area revealed a trend of buying and selling specific parcels of land several times within a short period and at an increased price. Some land speculators were observed to be holding land for making huge profit. In fact, as highlighted by Karki (2004), the increase in land value is the indicator of success in LR project. On the flip side, the case reveals that existing process did not facilitate in capturing land value for housing low-income groups. 


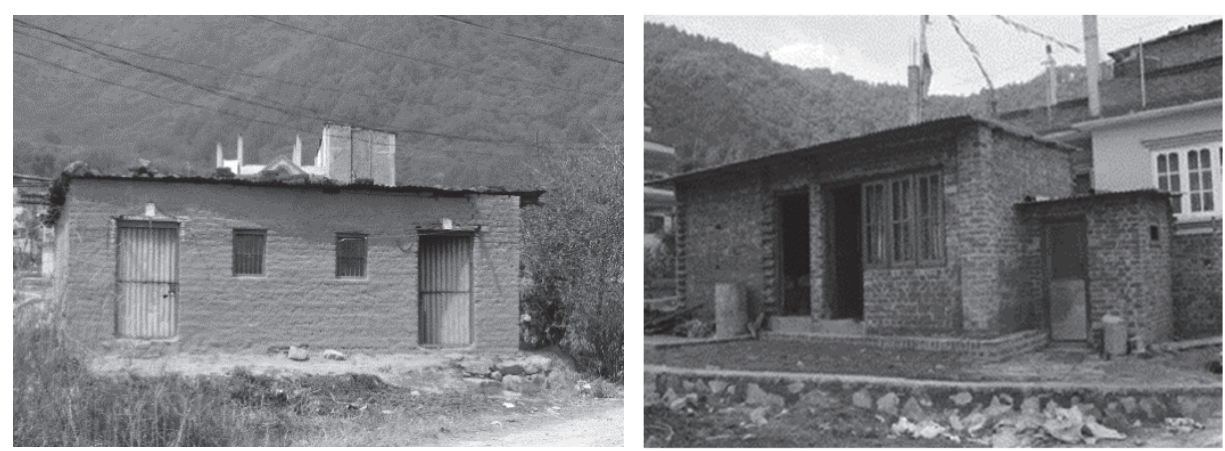

Figure 4 (a): Original house of informal settler Figure 4 (b): House constructed to one informal settlers who are residing within project area (Source: KVDA and author's own observation).

\subsection{Discussion of the action space framework and legitimacy}

i) Regulatory compliance in the allocation of low- income plots

Evidences of regulatory compliance could not be found in this case. Therefore, the government was unable to pull the action space towards the allocation of land for low-income housing. In the following sections, the paper discusses the findings with regard to regulatory compliance.

a) Legal norms for the participation of government, private developers, and private landowners

In this case, the LR process was not participatory with regard to the involvement of the government line agencies and the private sector in financing for the development of infrastructure. For example, government actors such as water supply, and electricity supply had unclear legal norms concerning their role in the LR process. Similarly, there were no clear regulations concerning investment from private developers. For this reason, government actors from other agencies were not involved, and private developers were hired as contractors. Given that neither the government line agencies nor the private developers made any actual financial contribution, the project ultimately imposed a financial burden over the landowners through an increased land contribution percentage. As highlighted in Sorensen (2000) and Turk (2007), the land contribution rates constitute one of the key factors that decrease consensus amongst landowners participating in the LR process. This subsequently leads to disagreement among the landowners in the allocation of land for low-income housing.

In this case, landowners participated in the LR process through the users' committee. With reference to Arnstein (1969) participatory ladder, the level of 
participation would fall on the uppermost rung, as the users' committee hold mandate to monitor the progress, spend budget of the project, and resolve land disputes. Looking at the reported lack of clear information regarding the beneficiaries of low-income housing, however, only a few of the landowners in the users' committee were involved. Although participation could be expected to empower participants in the decision-making process (see Arnstein (1969), Garau (2012a)), the legal norms for landowner participation, in this case, did not seem to be effective in convincing landowners in the allocation of lowincome plots. Therefore, the lack of effective implementation of legal tools created regulatory non-compliance in the allocation of land for low-income housing.

In short, the lack of provisions for government and market actors' participation hindered the legal compliance of setting aside a minimum percentage of land for low-income housing in the LR. As highlighted by Potoski et al. (2005), an intervention is required to eliminate the factors that hinder the regulatory compliance. Further, aligning with the study by Ferilli et al. (2016) regarding effective participation, the norms and values of government agencies, land owners and private developers need to be incorporated to obtain compliance with the set regulations.

b) Inclusive legal norms for the provision of low-income plots

In this case, there were no inclusive legal norms that could be ascertained from the land use after the LR process as highlighted by (Nisha, 2015), the $21.4 \%$ of reserve plots ${ }^{12}$ are bought for constructing of low-income housing. Unlike, Gujrat (Sanyal et al., 2012) and South Korea (Sandhu, 2004) there was no information concerning the percentage of land allocated to low-income plots. In the absence housing norms (Calamia et al., 2009), the government was not able to capture the land value of low-income housing. Rather, the government had to negotiate in the land market and purchase the land. In fact, the reduced market demand for the sales plots during the initial phase of the project was a prime opportunity for the government to purchase land. In most cases, however, the land is hardly ever purchased for low-income housing, due to the risk of a decrease in land values in the vicinity (Needham et al., 2004). As mentioned by Squires (2012), sales plots near the low-income housing tend to have lower market value. That is to say, due to lack of implementation of IH norms, there was regulatory non-compliance in allocating land for low-income housing.

ii) Regulatory noncompliance for the market actors in the allocation of lowincome plots

${ }^{12}$ Reserve plots and sales plots have same meaning and used interchangeably 
In this case, the market actors lacked a level playing field due to regulatory noncompliance in the allocation of land for low-income housing. The action space was pulled towards the market actors, who catered to high-income groups. The following section discusses the findings concerning the lack of level playing field due to regulatory noncompliance.

a) Participation of landowner in the allocation of low-income plots

In this case, there was no mechanism for creating market incentive for landowners to allocate low-income plots, as the costs of the project were fully covered by sales plots. The landowners thus had to contribute land in order to produce sales plots. High land contribution rates tended to lead to negativity towards LR projects (Archer, 1992). In this case, objections from landowners regarding the high land contribution rate led to delays in the execution of the project. Therefore, high land contribution provides evidence that the landowners did not have a level playing field in the allocation of low-income plots.

b) Inclusiveness by equitable access to land

In this case, an effort towards inclusion was adopted by not displacing the inhabitants who were already residing in the project area. Also highlighted in the study of (Nisha, 2015) about the mechanism adopted to prevent the displacement of land owners' from the project. In this regard, a level playing field was created through financing mechanisms intended to help landowners buy land. These financing mechanisms were intended to fulfill the technical norms of land area for those landowners residing within the project area and having too small plots. The project in this case also accommodated one settler who did not own any land, and yet was residing within the project area. Due to the lack of legal compliance, however, the LR process was unable to allocate land rights of the occupied land to that settler. In a case study involving LR in Turkey (Turk et al., 2014), there were legal instruments for recognizing informal rights giving legal compliance to allocate land.

Although the current case did involve an inclusion provision for settlers residing within the project area, there were no inclusion provisions for settlers residing outside the project area, particularly those from low-income groups. Increasing land prices, land speculation and the lack of mechanism to control land prices engendered no market legitimacy for the low- income people outside the project area. In addition, the project did not facilitate financing mechanisms for low-income groups (see (Supriatna et al., 2014)). Further, the government did not facilitate the efforts of private developers to buy land within the project area in order to develop low-income housing. As suggested by De Kam et al. (2008), bringing in low-income housing agencies as landowners can create a level playing field for catering to low-income groups. 
In this case, private developers were involved only as contractors. In other words, the LR project did not provide any legal basis upon which private developers could acquire land for housing development. The high cost of land acquisition reduced the willingness of developers to accommodate low-income groups (Ram et al., 2016). As highlighted by Needham and De Kam (2004), the lower profits associated with low-income housing can make projects less attractive to developers. A lag in the implementation of market-based instruments to provide equity between allocating land for high income and low income groups reflected the lack of a level playing field for market actors in the accommodation of low-income groups.

iii) Action space and legitimacy in the LR approach for the allocation of lowincome plots

In this case, there was a lag in the government action space in the LR approach to allocate land for low-income housing. With reference to the interpretative concept of action space, weakly binding regulatory compliance prevented governmental actors from regulating market actors in the production of the low-income plot. Due to the lack in effective implementation of Town Development Directives (TDD) in allocating $10 \%$ of the developed plots to the low-income housing, there existed the regulatory non-compliance. The absence of regulatory compliance pushed the government's action space towards market actors. This finding is consistent with Turk's (2008) observation concerning the difficulty of applying the LR approach to accommodate low-income groups. In Icchangu case, however, market legitimacy for low-income groups emerged when there were fewer buyers for sales plots. The government could buy land for low-income housing, thus shifting its role to that of the market actor. That observed, it can be stated the lack of regulatory compliance for allocating land for low-income plots forced the government to enter the land market. As argued by Van der Krabben and Needham (2008), the failure to capture value for low-income housing provides evidence of a lack in a government's action space in the provision of land for low-income housing.

The action space was also pushed towards the private sector, catering to highincome housing. This finding is contrary to the suggestion of Turk (2008), who placed emphasis on subsidies, the transfer of development rights and tax exemptions during the access to developed plots within LR for the production of low-income housing. In Icchangu case, however, no market interventions were applied to provide private actors' (for instance, private developers) access to developed plots within the LR project area. This indicates the lack of a level playing field for private actors, which resulted in a lack of market legitimacy in the development of low-income housing. This finding resembles with a case in India, where there was no willingness to supply low-income housing due to 
lack of level playing field for other than one actor (Ram et al., 2016). In the current case, therefore, the action space - even though it was more on the private actors' side - did not facilitate the private actors to provide low-income plot to low-income groups.

In line with other studies that demonstrate the need for involving both government and market actors in the provision of low-income housing (Sengupta, 2006), the case of Icchangu project reflects a need to balance the action spaces between the government and market actors to obtain inclusive development.

\subsection{Conclusion}

This paper concludes that the existing governance pattern in the LR approach is market dominant, catering the developed land to existing land owners in the project area and to the high income groups. LR project in Nepal confirms that there is a lack of "action space" for government actors with regard to regulatory compliance in the allocation of low-income plots in the LR process. Due to the absence of regulation, that is compliance with market norms, the level playing field could not be established between market actors while allocating land for low income housing.

The results from the case study of LR project suggest that Nepal's current governance pattern is unfavorable for the provision of land to low-income housing due to the lack of effective policy implementation. This is seen to result in the lack of inclusiveness and development induced displacement. This case study also confirms that there is a lack of "action space" for government actors with regard to regulatory compliance in the allocation of low-income plots in the LR process. The government was not able to enforce effective inclusionary housing norms thus leading to the regulatory non-compliance to capture value in order to provide land for low-income housing. In addition, the lack of legal norms for involvement of various government sectors that are providing services like electricity, water have hindered in making LR process inclusive. This is suggestive of the fact that the action space was pulled towards the market that catered land and housing for high-income groups, and thus failed to include the low-income groups. In contrast, there were clear deficiencies in the action space of market actors with regard to the allocation of land for lowincome housing, due to the lack of a level playing field.

Certain implications could be drawn from this case with regard to the concept of action space. This concept appears to capture the dynamics involved in the push and pull of the action space between government and market actors, while not undermining the effects of these dynamics on the allocation of land for low-income housing. It can therefore be concluded that the use of the 
analytical concept of action space to analyze patterns of governance offers an interesting perspective on the interaction between government and market actors. Such a perspective can be useful while attempting to balance the action space between government and market. The outcome of such balanced action can contribute towards inclusiveness of low-income groups within any development project.

For further studies, it could be interesting to modify the framework used in this study to focus on interactions between market and civil society actors and to explore the concept in other land development approaches. Further, it is recommended to consider civil society actors, particularly the logic and perception of low-income groups, while developing a methodological framework to obtain holistic analysis of LR process to accommodate lowincome groups. 


\section{Chapter 4: “Action Space” Based Urban Land Governance Pattern: Implication in Managing Informal Settlements from the Perspective of Low-Income Housing ${ }^{13}$}

13 This chapter is based on the published ISI article:

Shrestha, R., Zevenbergen, J., Masum, F., \& Banskota, M. (2018). "Action Space" Based Urban Land Governance Pattern: Implication in Managing Informal Settlements from the Perspective of Low-Income Housing. Sustainability, 10(7), 2202. 
Abstract: Understanding the governance pattern between civil society and market actors in allocation, access to, and use of land for low-income housing is important in managing the informal settlement. In this study, the concept of "action space" is conceptualized as a means to analyze the interaction between civil society and market actors. This novel approach is then applied to a resettlement project in Nepal as a case study. The analysis revealed the mechanism by which the "action space" was created and the push and pull of the "action space" among actors that led to various types of legitimacy. The results show that due to a regulatory vacuum a gap between market legitimacy and social legitimacy was created, resulting in a failure to cater land for lowincome housing. Analysis of governance patterns using the lens of "action space" offers an important perspective on how to minimize the gap between market legitimacy and social legitimacy.

Keywords: "action space"; civil society and market actors; informal settlements; land for low-income housing 


\subsection{Introduction}

Managing informal settlement in a sustainable manner is a global south issue that is associated with land and housing for low-income groups. According to Mason and Fraser (1998) managing informal settlements entails improving the quality of life of informal settlers by providing tenure security on land and housing as well as providing access to basic services with an acceptable standard. In order to manage informal settlement, Augustinus (2009) has argued for two types of interventions- a proactive intervention and a reactive intervention. With the proactive intervention, low-income housing is provided to the low-income groups. On the other hand, with the reactive intervention in situ upgrading of settlements or relocation of the informal settlers are carried out by providing security on land and housing tenure. When a settlement is located in an environmentally vulnerable zone, the relocation intervention is a better approach to managing the informal settlements (Gutberlet et al., 2016). Regardless of intervention type, several authors (Satterthwaite, 2009; Yap, 2016) consider the access to, allocation of affordable land as well as the use of land as a prime factor in the housing for low-income groups. Yet, existing challenges are associated with acquiring land for housing low-income groups (Faraj, 2014). This has been attributed to the weakness of urban land governance in catering land for low-income housing.

The major weakness in the urban land governance is the lack of balanced action among the three key actors: government, market, and civil society in the governance pattern (Shrestha et al., 2016a). The governance patterns basically refer to the action of various actors like government, civil society, and market and their dominant position in that period of action such as government-led governance, market-led governance, and civil- society- led governance (Foxon, 2013). For instance, Blessing (2012) has shown "state" and "market" dualism as core challenges in housing the low-income groups and concluded that the government and market need to take an integrated action. Similarly, the conceptualization of hybrid governance within the housing research has further amplified the importance to understand the blended action and the logic of government, market and civil society in the framework of social enterprise (Czischke et al., 2012).

The different logic of different actors in the governance pattern refers to various types of legitimacy. In this regard, the challenges that urban land governance faces are to enhance legitimacy in order to obtain optimal outcome to accommodate low-income groups (Shrestha et al., 2016a; Stoker, 1998). Legitimacy is defined as " a generalized perception or assumption that the actions of an entity are desirable, proper, or appropriate within some socially constructed systems of norms, values, beliefs, and definitions" (Suchman, 1995). Various authors have referred to different types of legitimacy in their 
studies - pragmatic, moral and cognitive legitimacy (Thomas, 2013), legal and social legitimacy (Shrestha et al., 2016a; Thomas, 2013) and market legitimacy (Hawn et al., 2011). In this paper, we refer to two types of legitimacy: social legitimacy and market legitimacy. In the market -led governance, the market does not accommodate the low-income groups due to lack of market legitimacy for allocating land for low-income housing. While considering market legitimacy for land development, it is a generalized perception that the actions of entity fulfill the market norms and value and the developed land support the economic growth. According to Durand-Lasserve (2006), there is a global context where land developed for economic growth is rarely allocated for housing the low-income groups because it requires land below market value. In contrast, the civil society-led governance pattern considers various social norms that need to be incorporated. Shrestha et al. (2016a) have explained the importance of social legitimacy, which is important to incorporate while considering low-income housing. Therefore, there seems the gap between social legitimacy and market legitimacy. The improvement of the urban land governance is embedded in minimizing the gap by considering the interaction between civil society and market actors.

The importance of the role of civil society and market actors are advocated in various studies. Ndezi (2009) has mentioned the importance of communitybased organizations (CBOs), NGOs to get involved in the resettlement process in a Tanzania case that shows how the weakness in policies and institutional framework can limit the participation. Similarly, Patel et al. (2002) have shown that by involving the community from the initial phase of a resettlement project in collaboration with CBOs, NGOs led to success. Yntiso (2008) argued for the participatory approach to involve communities and potential partners in decision making in order to understand their social needs. In the same line, Keuk et al. (2016) and Amado et al. (2016) have forwarded various shortcomings in the resettlement approaches that range from infrastructure provision to land tenure security due to the lack of an effective participatory framework to incorporate the private actors while constructing low-income housing. In addition, Garau (2012b) has mentioned that besides technical support, physical interaction between actors is equally important for achieving an effective outcome in the participation process. Yet, the mechanism of interaction between market and civil society and their governance pattern remain widely unexplored with regard to providing affordable land for housing low-income groups.

In order to understand the interaction among actors as well as the overarching governance pattern, various authors have applied the concept of "action space" in their studies (Foxon, 2013; Shrestha et al., 2016a). Similarly, Kågström et al. (2015) have conceptualized the space of action to understand the practitioners" "potential spaces for action", "actual spaces for action" and 
"interpretative spaces for action" while conducting Environmental Impact Assessment (EIA). Following Foxon (2013), this paper uses "action space" as a lens to understand the governance pattern and conceptualize it in the access to and allocation of land for low-income groups in order to manage informal settlements.

In this study, we analyze the governance pattern within the concept of "action space" and its legitimacy. We focus on the interaction between market actors and civil society actors in access, allocation, and use of land for housing lowincome groups. Though we highlighted the role of the market and civil society actors, the role of the government cannot be excluded. Therefore, we consider the government role as overarching. The case of resettlement of informal settlers in Kathmandu, Nepal was studied to understand the governance pattern using the "action space" concept. The paper finally provides the way forward to balance the "action space" of civil society actors and market actors.

\subsection{Urban land governance and legitimacy in managing informal settlement}

While referring to the weakness of urban land governance in allocating affordable land for low-income housing, the underlying challenges are about legitimacy (Stoker, 1998). Shrestha et al. (2016a) have shown that different governance patterns have different types of legitimacy. The state-led governance has legal legitimacy while civil- society- led governance has social legitimacy. The authors have further shown that in order to manage informal settlements the gap between legal legitimacy and social legitimacy in allocating land for housing the informal settlers needs to be minimized. Furthermore, the holistic approach hinted towards considering the market actors. While doing so, there is a challenge of dealing with market legitimacy because in the market -led governance the market does not automatically accommodate the lowincome groups (Hawn et al., 2011).

The social legitimacy is about considering the social norms and value and these are the essences of the civil society-led governance. The civil society -led governance pattern provides effective results in identifying land for housing low-income groups by applying a tool like a community-led enumeration. The approach adopted by the informal settlement federation of Mumbai was set as good practices of community-led governance in which the community led to land use plan was considered as the driving factor for enhancing the livelihood options. Kigochie (2001) has also shown that allocating land for house-based enterprises supported the income generating activities of the residents ${ }^{14}$ at the

14 The term 'Residents' is used to refer to the informal settlers who are resettled in formal housing 
relocated site. In addition, Patel et al. (2012) have explained the involvement of the community in gathering the information of available land and succeeding in achieving the social legitimacy. The information such as land ownership, available infrastructure, job options, and cost of the commuters to their present place of work helped to incorporate the social requirement of the informal settlers. Moreover, the information about the affordability of the land helped the community-led saving groups and informal settlers' federation in planning the relocation strategy.

Similarly, the market legitimacy is considered important in the market- led governance pattern while allocating part of their development to low-income housing. In the resettlement project, various literature (Satterthwaite, 2009; Turk \& Altes, 2010a) have shown that access to affordable land from the formal market is one of the critical factors that hinders development of low-income housing. In the similar line, Needham et al. (2004) have highlighted various constraints that affect the land provision for low-income housing, for instance, unaffordable land prices under formal market conditions, less profit in lowincome housing, the effects on a land value near low-income housing. Therefore, market legitimacy is important while enabling the market to contribute to the social goal.

\subsection{The concept of "action space" to analyze governance pattern}

The "action space" is an analytical concept to analyze the various governance patterns, i.e. government, civil society, or market led governance pattern. It provides the framework for analyzing the interaction between each combination of actors through their inter-relationship (Foxon et al., 2009). In order to conceptualize the interaction, governance pattern and legitimacy between market and civil society, the concepts of "citizen entrepreneurship" and "compliant consumer" are integrated into the "action space" as shown in Figure 10. If the "action space" is pulled towards the civil society actors, a new breed of "citizen entrepreneur" can be seen. Similarly, if the "action space" is pulled towards the market then "compliant consumer" - in which the market is seen to 'know best' and consumers simply comply with the price signals that the market sends. 


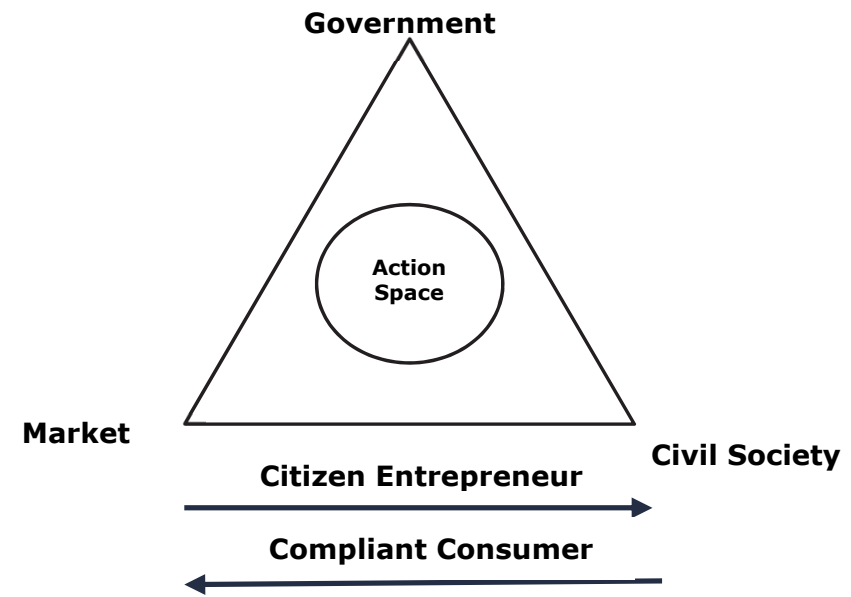

Figure 10: Analytical concept of "Action Space"

Adopted partially from Foxon et al. (2009) and modified by authors

\section{The Citizen Entrepreneurs within the Context of Social Entrepreneurs}

The "citizen entrepreneur" and "social entrepreneur" are inter-related concepts and are used interchangeably. The activities conducted by the citizen with profit goal is considered as "citizen entrepreneur" and when the entrepreneurship is oriented to the societal benefits rather than profit making, it is referred to as "social entrepreneur"(Bjerke \& Karlsson, 2013). It is materialized through the social indicators like participatory nature, an initiative launched by citizens, the social aim of the actions, which are performed to benefit the society by involving the affected citizens.

The social entrepreneur sets the "action space" created by civil society actor to achieve the social goal through economic orientation. There have been various studies that show the importance of social entrepreneurs in the housing sector for low-income groups (Czischke et al., 2012; Shrestha, 2010). Czischke et al. (2012) have conceptualized the role of the state, market, and civil society within the framework of a social enterprise in the housing sector depending upon mission and goal. Within the context of the social enterprise, social entrepreneurs are groom in the civil society sector where the activities refer to the economics-oriented towards a social goal. In some studies, this is referred to as hybrid governance as there is not a dominant logic of a single actor (Rhodes \& Donnelly-Cox, 2014).

The activities of civil society oriented from the economic perspective towards social goals are emerging in housing the low-income groups. Tripathi and Agarwal (2013) have mentioned that "action space" created by civil society groups towards social entrepreneurship has empowered the informal settlers 
in managing their own land and housing as well as in strengthening their economic condition. The evidence was set in the Indian case about the social entrepreneurship in the form of slum welfare cooperatives, housing cooperatives and banking cooperatives that facilitate the land and housing sector for low-income groups.

Social entrepreneurship, which is boosted by land use plan, is highlighted as an important component of resettlement plans for informal settlers. Kigochie (2001) has demonstrated that creating the "action space" in the income generating activities by providing land for initiating home-based enterprises has made the resettlement plan for the informal settlers successful. The success case of the Mumbai resettlement project shows that "action space" of community organization is created in the resettlement process by involving informal settlers in the selection of land, planning, and designing of resettlement plan and managing financial resources through women cooperatives (Patel et al., 2002).

The above theoretical background supports the analytical framework of "action space" of civil society within the context of a social entrepreneur. As shown in Table 1: the role of a social entrepreneur can be contextualized differently at the strategy level and project level. The social entrepreneurs in the strategy level contribute to the access to land for low-income housing. Similarly, at the project level, the land use plan can create "action space" that can support social entrepreneurship by individual residents

Table 8: Analytical framework of Social Entrepreneur.

\begin{tabular}{ll}
\hline Level & Role of Social Entrepreneur \\
\hline Strategy Level & Access to land for low-income housing \\
Project Level & Land use planning \\
\hline
\end{tabular}




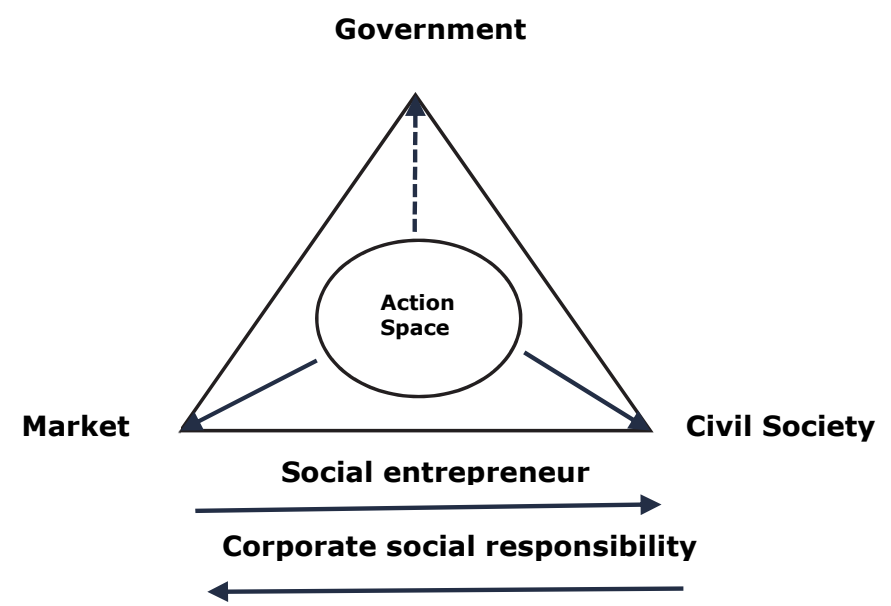

Figure 11: Analytical framework of "Action Space" to analyse governance pattern between market and civil society actors

(Adopted from (Foxon et al., 2009), (Foxon, 2013) and modified by the author).

\section{Compliant Consumer within the Context of Corporate Social Responsibility (CSR)}

The "compliant consumer" is conceptualized in the market- led governance by (Foxon et al., 2009) and refers to the target groups who are compatible with the price signal sent by the market. Within the context of land development, market-led governance refers to the sole action of private developers in the provision of developed land. In the market dominant governance, the consumers are usually high-income groups who can afford the price in the formal market for land and housing. As such, this formal market does not serve the affordable land for housing low-income groups. Therefore, to bring the lowincome groups within the "compliant consumer" there is a pressing need for the market intervention. In this context, the Corporate Social Responsibility (CSR) has been found to be conceptualized in the housing research to incorporate low-income groups (Othman \& Mia, 2008).

CSR has been brought into practice in different contexts in order to pull the market actors towards social goals. CSR has been considered as a concept in bringing the consensus amongst private sectors to extend the role and responsibility of business beyond profit-seeking and in which companies see themselves as a part of a wider social system (Badulescu et al., 2018). Within this context, as highlighted in Turk et al. (2010a), via CSR, the government can bring the intervention in the market sector with market legitimacy to obtain the social goal. Tang et al. (2018) has provided evidence in the Chinese case about the role of government in guiding private enterprises to fulfil CSR. 
Several authors have agreed on CSR as a potential concept to incorporate private developers in the allocation of land for affordable housing (Adams et al., 2008; Turk et al., 2010a). Similarly, Othman et al. (2008) have shown the use of CSR to involve SAQS (South African Quantity Surveyors), a private sector, for technical support in facilitating housing development at low cost. The authors have mentioned the various actions, which hinders the delivery of housing for the poor, promoting community involvement in the design process. CSR has also been considered in facilitating the financial process in acquiring land and housing as well as in information counselling to develop low-income housing. Likewise, (2008) have mentioned the CSR as an approach to enforce the developers to allocate land for low-income housing. It can be applied as a condition to obtaining the development permits for the private developers. In addition, Gooding (2016) has indicated that the intervention in private sector housing provision under a theme like CSR is a feasible way to effectively meet the land and housing need of low-income families. Aligning with the provision of low-income housing, Wilson et al. (2016) have shown that the regulatory vacuum to use the CSR of the private sector in allocating land for low-income housing has affected the low-income groups in the case of Pennsylvania. Therefore, CSR is the potential concept to direct the private developers action towards social goal as well.

The above theoretical background supports the analytical framework of "action space" of market actors within the context of CSR. As shown in Table 2, the role of the CSR can be contextualized differently at the strategy level and project level. The CSR at the strategy level contributes to the allocation of land for low-income housing. Similarly, at the project level, the technical support for land and housing development can be regulated with CSR.

Table 9: Analytical framework of corporate social responsibility.

\begin{tabular}{ll}
\hline Level & Role of Corporate Social Responsibility \\
\hline Strategy Level & Allocation of land for low-income housing \\
Project Level & Technical Support for low-income housing \\
\hline
\end{tabular}

\subsection{Methodology}

The "action space", which is the analytical framework for analysing governance pattern, is conceptualized here to understand the interaction between civil society actors and market actors in managing informal settlements. This novel approach was applied in the case of a resettlement project named the Kirtipur Housing Project (KHP) in Kathmandu, Nepal.

The case was analysed using the scale and level concept. According to Cash et al. (2006), the mismatch in the scale and level is one of the challenges in governance. (Gibson et al., 2000) defined "scale" as spatial, quantitative, analytical dimensions applied to study any phenomenon and "level" as the unit 
of analysis, which is located at different positions on the scale. Cash et al. (2006) have presented schematic illustrations of different scales and levels. In this study, we applied the management scale, which consists of different levels. We have combined the policy and strategy level to one level and then to project level to analyse the governance pattern.

Data were collected using a semi-structured household interview with the residents of KHP, a semi-structured interview with key informants and a review of documents related to case sites. Applying the scales and levels as adopted in this study, we gathered the views of residents within the period of two years (December 2013 and March 2016). The latter field visit was conducted after the devastating earthquake of 2015 in Nepal, with the rationale to strengthen the data collected in 2013. Altogether 27 respondents participated in the household interviews in both years. Additionally, participants for semistructured interviews included key informants of the KHP, government actors, civil society actors, NGOs and market actors. The semi-structured interview was directed towards collecting an overview of land/housing policy and practices for low-income housing. The review of literature was carried out to understand the process of resettlement at the project level

\subsection{Case Study}

\section{The Kirtipur Housing Project (KHP)}

The Kirtipur Housing Project (KHP) is a resettlement project for informal settlements residing along the Vishnumati River banks in the Kathmandu Valley (see Figure 12). The three actors (government, market, and civil society) were involved in this project. However, the project was dominantly led by the civil societies (see for detail (Sengupta \& Sharma, 2009)). Table 10 shows the role of three key actors - government, market, and civil society - in the KHP. 


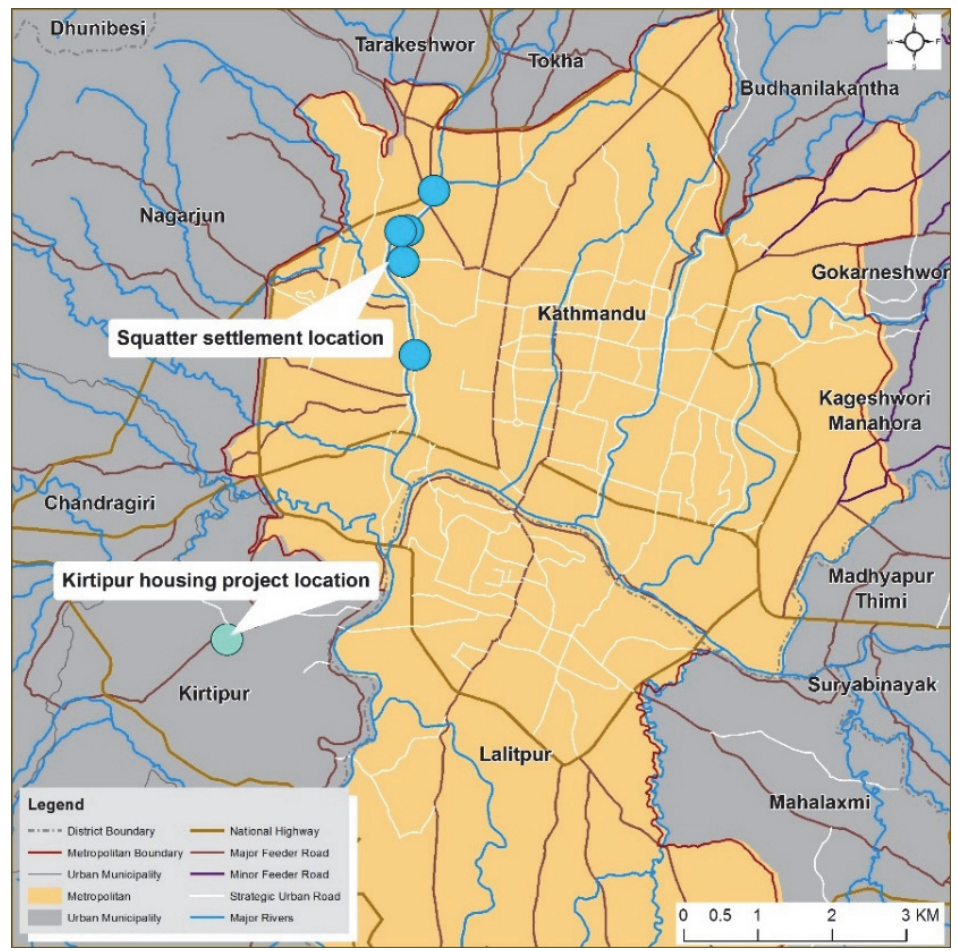

Figure 12: Location Map of relocated informal settlements (squatter settlement) and Kirtipur housing project (KHP)

(adopted from (Sengupta et al., 2009)). 
Table 10: overviews of activities and actors involved in KHP (Source:(Sengupta et al., 2009) and Authors' Field Visit).

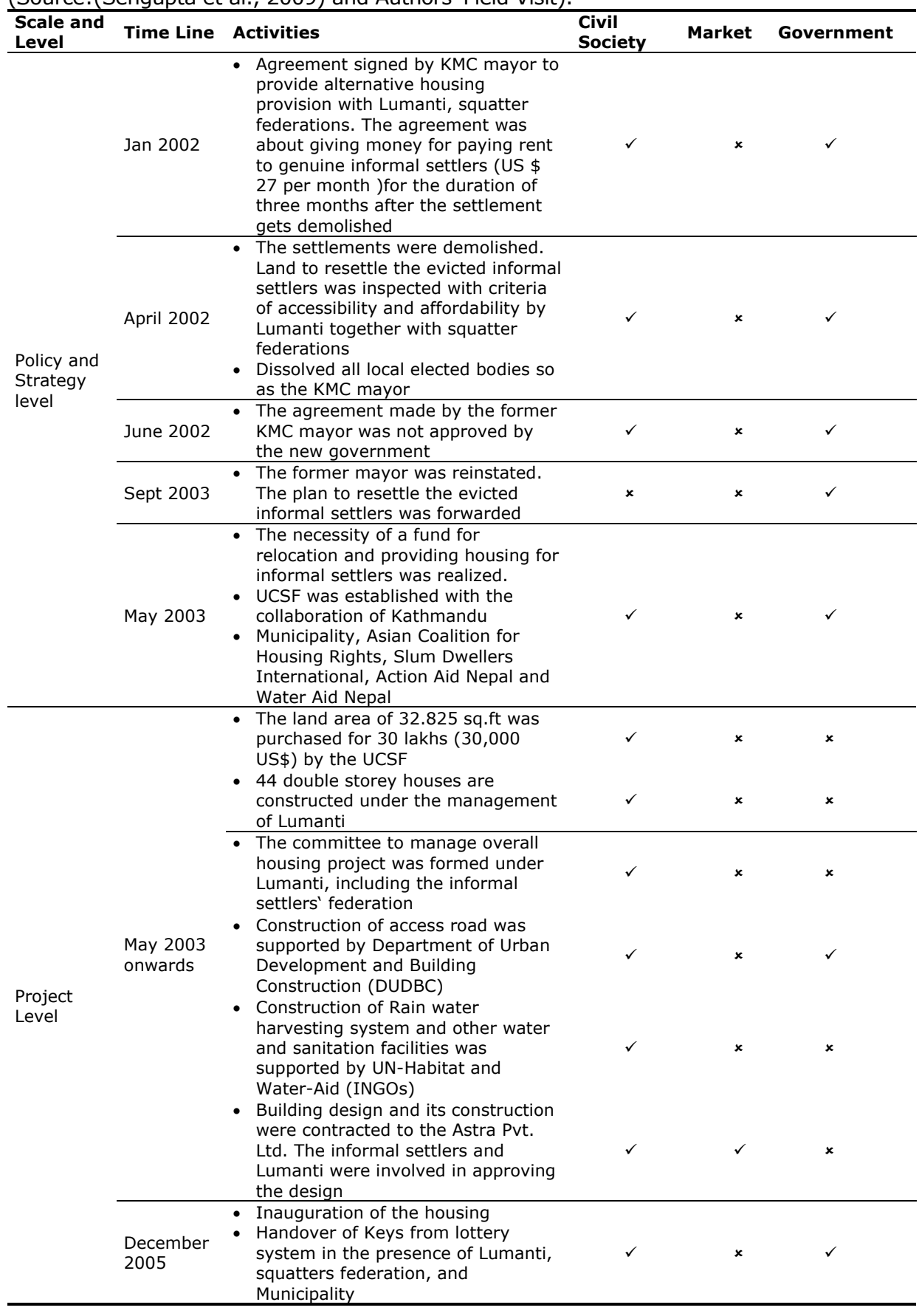


In January 2002, the government published a notice for the clearance of the road construction site. In response to this notice, the affected informal settlers with the support from Lumanti support group (NGO), squatter federations, other NGOs and civic groups resisted for the demolition plan of government of their houses without an alternative resettlement plan. The lobbying from Lumanti succeeded to make the "landmark agreement". The agreement stated that the informal settlers identified as "genuine settlers" would be provided with financial support for rental accommodation for three months and thereafter they would be provided with an alternative housing (Sengupta et al., 2009).

In April 2002, the settlements were demolished. The informal settlers moved to the rental houses in a nearby area. During the process, Lumanti had frequent contacts with the informal settlers to plan for the relocation. Unfortunately, in June 2002, political upheavals in the government system led to the dissolution of all the elected local bodies and dismissal of the Mayor. This affected the implementation of the "landmark agreement".

In September 2003, the political twist reinstated the former Mayor. The agreement was made to grant 8 million rupees (US\$15 80,000) for relocating the affected informal settlers (Sengupta et al., 2009). However, the allocated budget was not enough. To align the financial arrangement from various organizations it was necessary to arrange a viable framework to administer the fund. Therefore, a finance fund was set up in the form of Urban Community Support Fund (UCSF) with financial contributions of the Kathmandu Municipality, Asian Coalition for Housing Rights, Slum Dwellers International, Action Aid Nepal and Water Aid Nepal. Lumanti administered the UCSF. A total of 20 million rupees (US $\$ 20,000$ ) was eventually raised (Sengupta et al., 2009). The objectives of the UCSF were set as follows (Lumanti, 2005):

- To provide secure housing ownership to the target group by providing lowinterest financial support for purchasing land and for housing improvement

- To provide financial access to the target group by providing capital for income generating activities

- To support the target group in fulfilling their basic social and physical needs

- To support in access to land for a civil society for developing low-income housing

\footnotetext{
${ }^{15} 1$ US\$ is equivalent to 100 rupees is considered as a conversion rate
} 


\section{KHP at the Strategy Level}

A six ropani (equivalent to $32.825 \mathrm{sq}$. $\mathrm{ft}$ ) piece of land was purchased at Paliphal in Kirtipur. The cost of land was 3 million Rupees (US \$ 300000) per ropani and was covered by the Urban Community Support Fund (UCSF). This project was considered the first project funded by the UCSF for access to land and housing for low-income groups. The choice of location was agreed on by taking into accounts the needs and preferences of the beneficiaries. The available budget and accessibility from the centre of the city were important criteria that were considered. Furthermore, the social stigma attached to the informal settlers was also a prime criterion because the existing communities might be offended by the relocation of the informal settlers near their neighbourhoods. Therefore, the location was away from the existing neighbourhood.

\section{i) Allocation of land and housing from the market}

Forty-four dwellings were constructed with active participation from the beneficiaries. Primarily, the nature and type of houses, materials, and facilities were determined by the beneficiaries based on the repayment amount. The residents needed to pay monthly around Rs 2000 (US\$20). It consisted of a row of housing with a common open space that can be used as playgrounds and for other purposes. Two types of housing plans were prepared. The housing price differed according to the layout of the toilet. The monetary value of houses was Rs 330000 (US\$3300) and Rs 350000 (US\$3500) respectively. The house was owned by UCSF until the loan was repaid. The UCSF had provided the loan to the settler in the interest rate of $3 \%$ per annum and the repayment period of 15 years. The private housing developer, Astra Pvt. Ltd was involved as a consulting developer for the planning and design of the house in KHP.

\section{KHP at the Project Level}

In the following sub-section, the KHP project is explained in its various project stages.

\section{i) Project Identification and Feasibility Phase}

a) Involvement of community in the feasibility plan of land use

Most of the residents ( 18 out of 27 respondents) stated that they were involved in the feasibility phase of the project (see Figure 13). As reported by Sengupta et al. (2009) the choice of the location of the site for relocation was considered according to the need and preference of the residents within the available budget. The present location was considered as an optimal choice in 
accordance with the criteria of affordable land for low-income housing. However, a compromise was made between integration with existing communities and impact on the employment. Of 27 respondents 20 mentioned that the current land use and its location was not accessible enough to support their income generation activities (see Figure 14). Most of the residents are vegetable vendors, house cleaners in the core area of the city which is some $10 \mathrm{Km}$ from the current relocated area.

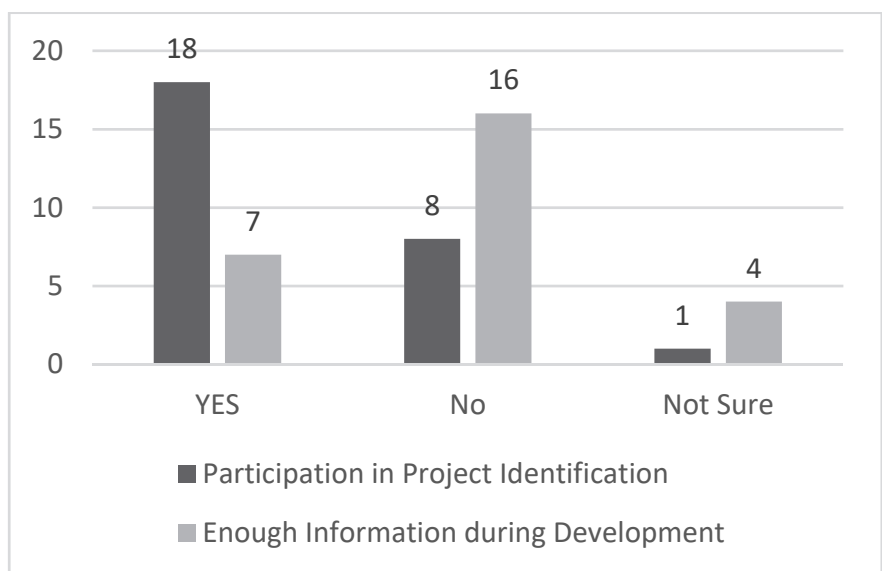

Figure 13: Residents' view on the involvement in the KHP Project.

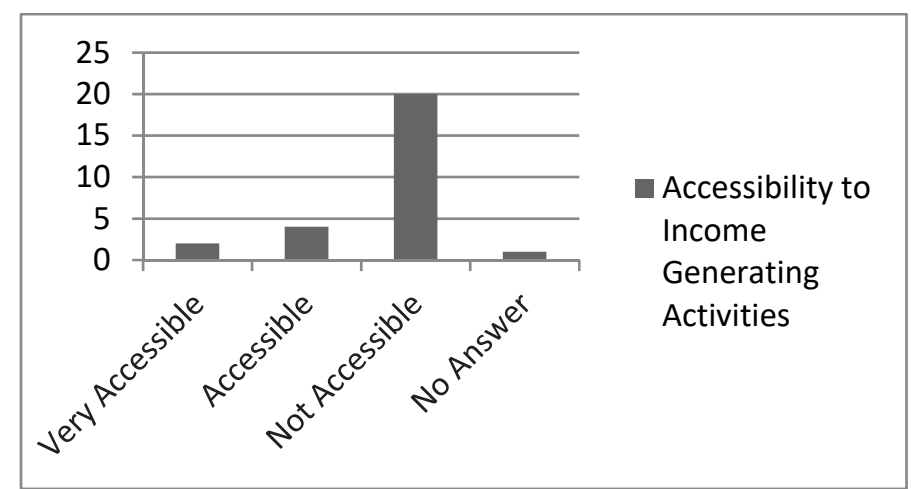

Figure 14: Residents' view on the accessibility to income generating activities.

b)Technical Support in the land development

The local knowledge was applied in order to understand the feasibility of the site for relocation. The private developers were not found to be involved in the feasibility of the land development process. The technical support and manpower such as surveyors for surveying the feasibility of area for the lowincome housing were not selected from private sectors. Moreover, the technical 
recommendations from highly skilled expertise for proper drainage provision seemed to be lagging.

ii) Project Planning and design

a) Community involved in the land use plan

The land use pattern of KHP consists of two common open spaces. The use of the open spaces was not defined during the project. The open space was allocated to make a garden (interview: officials from Lumanti). The land use plan did not seem supportive in improving the economic condition. Only four respondents stated that their economic activities were supported by the present location. In contrast, 17 residents stated that their economic activities were not supported at the current location Figure 15. Moreover, it was observed that the residents were using the open space for carrying out activities to enhance their financial situation (See Figure 16). This was again attributed to reduced accessibility of the current location from the areas of income generation as shown in (Figure 5) as well as lack of land allocation for conducting their income generating activities.

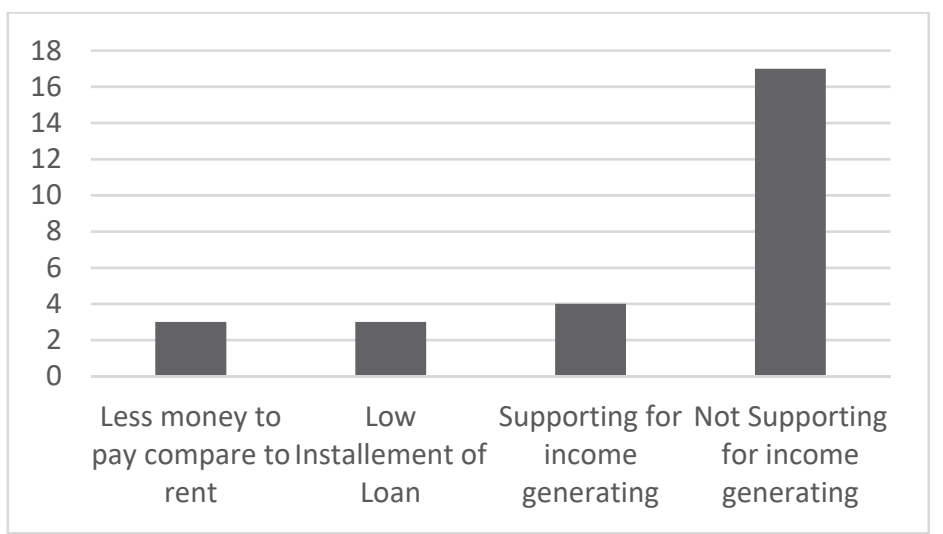

Figure 15: Residents' perception on land use for economic improvement. 


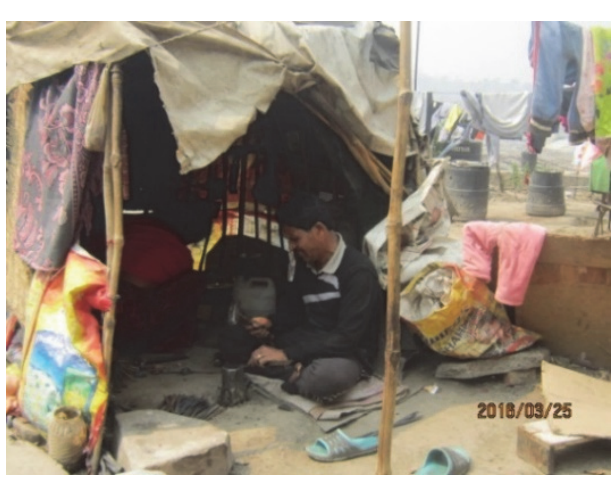

a) KHP residents using common space for making metal souvenirs

Figure 16: Common open space used for social entrepr resident

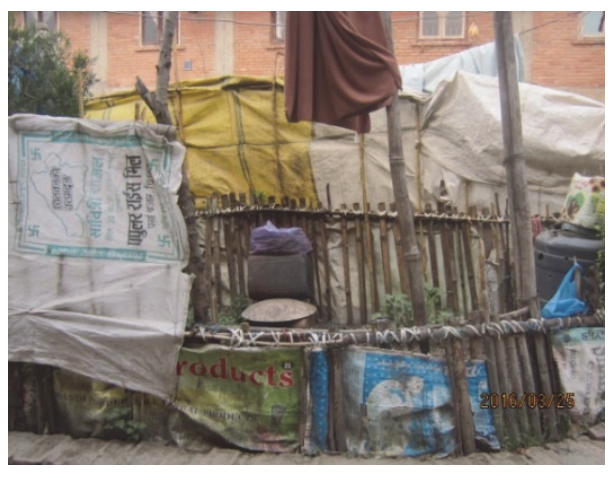

b) KHP residents using common space for farming

With regard to financial support, there was a general view that the payback method of housing loan supported their financial condition. As stated by three respondents, the amount they had to pay monthly for the house was less than the payment for rental accommodation (see Figure 17). Most of the residents (16 out of 27 respondents) felt that the information given during the project planning was not enough. This was reflected in the view of one settler as follows.

"In the initial design of the house, there was concrete slab in the roof but during construction, the roof is covered with Zinc. We cannot use the space in rooftop" (residents comment).

The management committee of the housing was formed under the aegis of Lumanti. The management committee included members of the residents themselves. The committee was mandated to manage all the transactions for the project including making payments to the contractors/ consultants and decision making on the design/ layout.

b) Technical Support for Land and Housing Development

There were various government and non-government organizations involved in the construction of service infrastructure. The stone paving in the access road was carried out by the government sector (DUDBC). Two wells were constructed and rainwater harvesting was introduced with the support of UNHabitat. Three underground tanks were built to collect rainwater. For the optimum usage of wastewater, a treatment plant was also installed so that treated water could be reused for various purposes like washing, cleaning etc. The water filter was constructed by Centre for Integrated Urban Development 
(CIUD) and Water Aid contributed to the construction of water and sanitation (Sengupta et al., 2009). Astra Development Network Pvt Ltd. was involved in the design and construction of the housing unit. The interview with Astra officials revealed that the consultant fee was reduced in the design and construction of the building. The letter of appreciation was given to the consulting firm by UCSF for the support they had given.

iii) In Project Monitoring

a) Involvement of the community and use of land for enhancing economic condition

The residents were not allowed to sell their housing unit on the free market. The awareness regarding the permission required by the management committee to sell their housing unit was shown by 17 out of 27 respondents. The value of their housing unit and the beneficiaries were determined by the management committee. The residents did not seem to know whether they could use their housing unit for rental purposes. Nineteen respondents perceived that the value of their housing unit should rise due to the increase in their land value resulting from the increase in land price in the vicinity. Nonetheless, 8 respondents did not perceive any changes in their housing unit. They were aware that the value in the vicinity did not apply to their housing unit as it was not possible to sell it at market value. Moreover, they did not possess legal documents of rights to land and house until they paid their entire loan. Therefore, the house was not considered as the increment in price by the respondents. Regarding the willingness to sell their house, 10 out of 27 respondents were unwilling whereas 15 seemed to be in a dilemma.

The data on the repayment of the loan in 2016 showed that out of 42 residents only 10 residents were able to pay the full amount (see Figure 17). The allocated period for loan repayment is 15 years. However, more than $50 \%$ of the residents had only paid less than half of the total amount within the period of 11 years. This reflects that during the given period the residents might not able to repay the entire amount. There was already a case where one of the house was sold through the management committee because the owner was not able to pay the amount of the loan within the allocated time (Interview with the residents: 2016). 


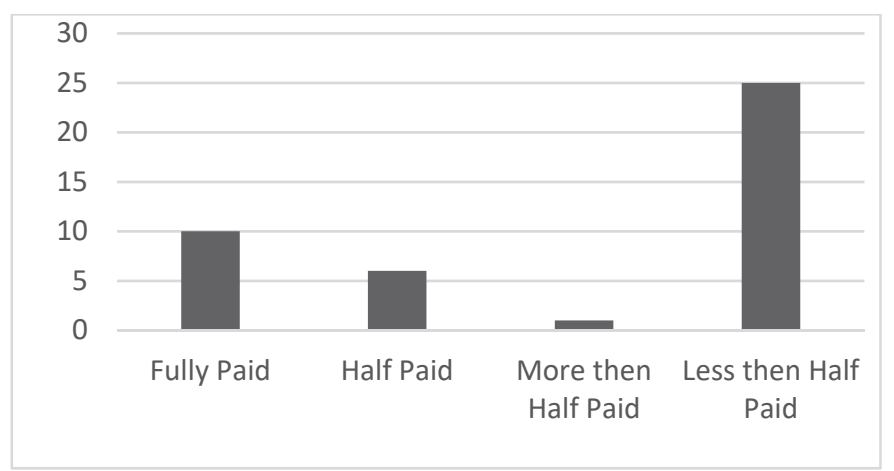

Figure 17: Loan repaid by KHP residents in 2016 (Source: Lumanti).

The lack of clear legal provision on the exemption from the land and housing tax for low-income housing residents created social unrest among residents. The residents were in fear of displacement from the current settlement due to failure to pay municipality tax for land and housing. During the interview with a government actor, it was revealed that there was no provision to redeem the tax for low-income housing (Interview: Kirtipur Municipality officials 2016). Therefore, the residents did not feel secure from the perspective of land tenure due to tax issues on one hand and on the other hand, they were in a dilemma if they would be able to pay the loan of the house.

The humiliation and social stigma exist among the residents (see Figure 18). It revealed that the current land use pattern and tenure were not able to wipe out the social stigma towards informal settlers. However, as they were able to buy the house, some self-respect and dignity could be seen among the residents. This was reflected in the view of one of the residents as below:

"We are still addressed as a 'Sukumbashi ${ }^{16}$ ' basically when we go to fetch water in the local community. We are paying money for the house so we should not be treated as 'Sukumbashi'"

\footnotetext{
${ }^{16}$ Sukumbashi is local terminology applied to define informal settlers
} 


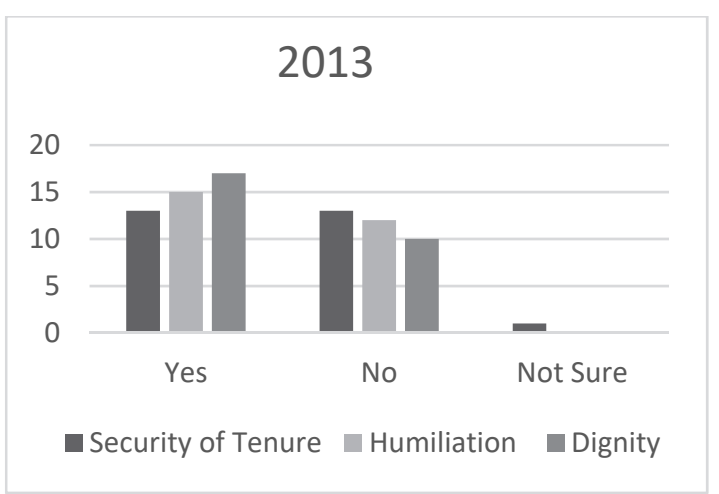

a) KHP residents' perception (2013)

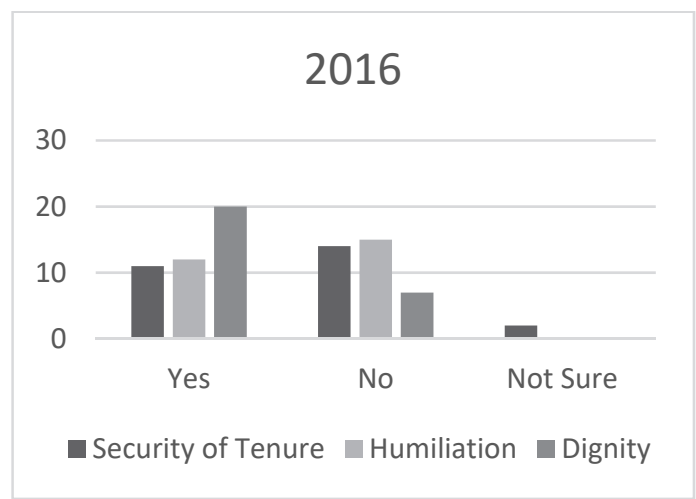

b) KHP residents' perception (2016)

Figure 18: Residents' perception on social aspect

b) Technical Support for the services

Most of the residents were satisfied regarding living condition in the resettlement site as compared to their previous settlements. Nonetheless, a few seemed to remain dissatisfied as observed in both periods. The residents were dissatisfied regarding the services. During the field visit in 2013, they complained about the electricity provision, drinking water and sewer problem. Although each household had a sub-meter, however, they needed to pay more according to the main meter, which was always higher, than their own use. The complaint still existed during a field visit in 2016. It revealed that the provision of individual electricity meters was linked with the use of land under individual ownership. Since the household does not have individual possession of the land occupied by their housing unit, they were not able to get the individual electric meter and water tap. 


\subsection{Analysis and discussion}

In this section, social entrepreneurship and CSR are analyzed and discussed in two-level (policy strategy and project level)

\section{Social Entrepreneurship}

\section{i) Policy and Strategy Level}

The case of the Kirtipur Housing Project (KHP) has shown that the "action space" of NGO and civil society was created by formulating Urban Community Support Fund (UCSF). The UCSF has a social goal of providing financial assistance for the low-income groups while buying the land for housing or improving the housing that aligns with the characteristic of social entrepreneurship as defined by Rahim and Mohtar (2015). The "action space" created through the UCSF for accessing land from the formal land market contributed to the success of the resettlement project. The land is the critical factor for housing low-income groups (Nientied \& Kalim, 1986; Satterthwaite, 2009). A similar initiative has been shown in the study of Tripathi et al. (2013). The financial cooperative that was established by the informal settlers' federation with the support from the NGOs contributed as social entrepreneurship that led to the economic empowerment of the informal settlers, thus, enabling them to invest in land and housing. The UCSF also seems to be an approach towards social entrepreneurship as it provides financial assistance for informal settlers in income generating activities and supports them to buy land for housing or improving the housing. This aligns with Wilson and Gran (2007), who have also reported the important role of NGOs and Community based organization in bridging the market gap for lowincome groups.

However, the "action space" of NGOs and civil society in the form of social entrepreneurship has not been incorporated into the legal framework. Though the "action space" is created on the civil society side by conceptualizing the social entrepreneurship, there is the regulatory vacuum, meaning that no intervention in the market sector to enhance social entrepreneurship exists. The land and housing tax for the KHP was calculated under the same regulations as it is calculated for a housing unit developed by the private developer. The regulatory vacuum regarding land and housing tax redemption for low-income housing shows a lack of "action space" of civil society in achieving the social objectives.

Moreover, the role of NGOs and civil society as social entrepreneurs have not been incorporated into policy and into the process of delivering housing for low-income groups at a national level but their role has been limited only in 
the project level. In addition to the case of KHP, the eviction case of one of the informal settlements that reside along the river of Kathmandu in the year 2002, as described by Shrestha et al. (2014b) and Shrestha and Aranya (2015a), reveals a failing case of resettlement. The rationale was the difficulties in the access to land for the relocation due to the lack of market legitimacy for allocating land for low-income housing. The land developed for profit-making is rarely allocated for housing low-income groups (Durand-Lasserve, 2006). In addition, the social stigma associated with the value of land near the lowincome housing is another reason for the difficulty in the access to land (Needham et al., 2004). In spite of this, the UCSF has succeeded in providing access to land with market legitimacy but there still seems a lack of the social legitimacy of the residents. The intervention strategies to fulfill social legitimacy has been highlighted in the study of Shrestha et al. (Shrestha et al., 2016a). For instance, creating job opportunities in relocated sites and, provision of security of tenure. Hence, the scaling up of the social entrepreneurship of the NGOs and civil society groups at the national level seems important in order to increase the chances for the access to land to resettle the informal settlers.

ii) Project Level

The KHP case has shown that the current land use pattern in the project area does not contribute to the economic enhancement of the residents. It reveals that there is a lack of social entrepreneurship with respect to the land use within the project. As described by Ferguson (2007), the success of the resettlement project depends upon the use of land such that it supports the social entrepreneurship of the residents in order to generate their income. The lack of "action space" in order to use the land for social entrepreneurship has been reflected in the lagging of the repayment of the loan by the residents within the specific period. This justifies the Kigochie (2001) argument about the necessity of home-based enterprises in the newly relocated site.

The case reveals that the residents are involved from the initial period of the KHP. As highlighted by Sengupta et al. (2009), the KHP is one of the successful community-led resettlement projects. Patel et al. (Patel et al., 2012) also mentioned that community-led governance considers social norms and value creating social legitimacy. However, the residents' views reveal that KHP has not been able to cater to the social values. The land use pattern does not seem to contribute in bringing social cohesion among the residents.

In addition, the land parcel that has been allocated for housing unit is not under the individual ownership of the residents. These legal issues regarding land ownership and use of land have triggered financial unrest among residents. Further, in the KHP, there is a restriction on the access to electricity meter in 
the individual housing unit. The provision of combined electricity meter has created social conflict among residents because they have to pay the electricity charge equally despite less consumption. Further, as mentioned by De Soto (2000) in his book "The Mystery of Capital", the residents could not use their housing unit for the mortgage because of lack of formal title of land. In contrast to De Soto (2000), Gilbert (2002) has clearly mentioned that the formal titles could not support low-income groups in the access to credit from formal financial institutions which provide loan with high-interest rates. In addition, Durand-Lasserve (2006) has explained the market gentrification of the informal settlers after issuing formal title of land use. However, there are various cooperatives that were focused on social entrepreneurs and provide a loan to low-income groups (Tripathi et al., 2013). In Nepal as well there are cooperatives initiated by informal settlers federations established with a social goal rather than a financial goal. These cooperatives are facilitating the financial support to the low-income groups. The detail of the cooperatives has been explained in (Shrestha et al., 2014b; Tanaka, 2009).

Despite above-mentioned weakness in the case about the land use pattern as being not supportive in the social entrepreneur, however, modality adopted by project by not allowing the residents to sell the housing unit by themselves created "action space" for civil society to oppose market gentrification.

\section{Corporate Social Responsibility}

\section{i) Policy and Strategy Level}

Various authors (Adams et al., 2008; Gooding, 2016) have argued that the CSR is a feasible approach to create an "action space" of private developers in allocating a certain percentage of their developed land for low-income housing. In this regards, the KHP case reveals that the action of the private actors has not been conducted under the framework of Corporate Social Responsibility (CSR). The private developers were not involved as a market actor in the process of land delivery for housing low-income groups. Instead, they were hired as contractors for planning, design, and construction of the housing unit. The lack of inclusive land policies and strategies to deliver land for housing low-income groups enforced the NGOs and civil society to access land from the formal market. As such, "action space" is pulled towards the market logic. This has given rise to the market led governance in the land and housing sector that is oriented for developing land for economic growth. As a result, only highincome groups were catered. As explained by Foxon (2013), the high-income groups are the compliant consumer in the market form of land delivery.

Therefore, the intervention in the market form of land delivery for housing the low-income groups is required which was articulated in (Paris, 2007). 
Moreover, while doing so, market legitimacy is important to be considered. As (2010) mentioned private organization requires market legitimacy. In this line, (2008) have mentioned market instruments like tax redemption and provision of development rights that can be integrated into CSR for allocating land for housing low-income groups.

ii) Project Level

Considering the use of land at the project level, Hong Sharon Yam et al. (2010) mentioned that private developers can fulfil CSR by developing recreational park, green spaces and good infrastructures. However, the housing for lowincome groups is sensitive to house price and fulfilling the basic accommodation needs rather than other recreational facilities. Therefore, private developers can contribute in providing technical expertise to use the land effectively in constructing housing at a low price. The KHP case reveals the private consultant had designed the housing unit of the project. Furthermore, the consultant did not seem to be involved within the framework of CSR like providing subsidies and waiving the consulting fee in the housing design, consultation in applying low-cost technology. The lack of private sector involvement in the case of KHP was mentioned in the study of (Sengupta et al., 2009) as well.

The result of the lack of private sector involvement was illustrated in the monitoring and maintenance phase of the project. The lack of technical support in the maintenance of land that was used for the rainwater harvesting had left the infrastructure unused. This technical constraint can be overcome by creating "action space" of the private sector within the CSR framework (Othman et al., 2008).

\subsection{Conclusion}

In this paper, we have explored the concept of "action space" and translated this concept into housing for low-income groups by conceptualizing the "Social Entrepreneur" and "Corporate Social Responsibility" (CSR). The civil society has created its own "action space" by setting the Urban Community Support Fund (UCSF) for the provision of land and housing to the low-income groups. This shows the shift from the managerial governance pattern - the government as the provider- towards the entrepreneur- the government as the facilitator. The case shows the trend of the social entrepreneur by formulating a platform like UCSF, however, this initiative remained at the project level. The scale-up of the concept of "Social Entrepreneur" to the policy level in order to formulate national strategies towards access to land for housing low-income groups remains a vacuum. Ultimately, this indicates that the intervention towards managing the informal settlements at the country level is lagging. 
While referring to the market actors like private developers, the case clearly demonstrates that there is no binding legal framework to pull the private sectors towards the social goal. The concept of "Corporate Social Responsibility" is not framed in the regulation of the private sector in the provision of land for housing low-income groups. Due to the lack of private sector, involvement in the housing delivery for low-income groups has been skewed towards government and civil society. This has resulted in a short-term solution at the project level.

Besides the fact that the translation of the Social Entrepreneur and CSR concept to the policy and strategy level is important, it should be translated into project level as well. Looking into the project level, the case shows how the lack of land use plan that supports the social entrepreneurship of the individual residents reflects a failure to capture social legitimacy. In addition, the lack of market actors that play a sufficient role in the consideration of technical support in the context of use of land is lacking. The "action space" created for private developers in the concept of CSR seems to affect an effective approach towards solving housing issue from a land perspective.

This paper contributes at the conceptual level to analyzing the governance patterns. The analytical framework of "action space" has been able to capture the dynamics involved in the push and pull of the "action space" between market actors and civil society actors, as well as the effects of this dynamism on the allocation of land for low-income housing. We believe that the use of the analytical framework of "action space" offers an interesting perspective on analyzing the governance pattern between market actors and civil society actors in general. In addition to the conceptual contribution, this study makes a societal contribution to the process of access and allocation of land for housing low-income groups in particularly. Housing for low-income groups has remained an issue in the global south for decades. However, most of the housing-related studies have focused on designing affordable housing rather than tackling the land issues for low-income housing. In this context, we feel that this study contributes to the existing literature on housing studies by conceptualizing the notions of Social Entrepreneur for access and CSR for allocating land for low-income housing. In doing so, it further assists in narrowing the gap between market and social legitimacy in the housing the low-income groups, taking the land issue as a point of departure.

Finally, this paper concludes that the concept of Social Entrepreneur and CSR can narrow the gap between social legitimacy and market legitimacy by balancing the "action space" of the market and civil society actors. Narrowing this gap needs attention both at the project level as well as scaling up to the national level in regard to access to and allocation of land for low-income housing for managing the informal settlements. 


\section{Chapter 5: Integrating the three key actors in the "Action Space"17}

\footnotetext{
17 This chapter synthesizes the outcomes of Chapter 2, Chapter 3 and Chapter 4 and brings the implication of the findings from those Chapters towards the integrated framework of "action space".
} 


\subsection{Introduction}

Understanding the urban land governance by integrating both the actions and logic of three key actors (government, market, and civil society) is the main objective of this research. In order to analyse the actions and logic, this study has adopted the "action space" concept. Furthermore, this study explored the interactions between two actors in each arm of the "action space" (see Figure 1). After exploring the interactions among the three key actors, several lessons are learned at the conceptual level of the "action space", as well as at the different case levels (elaborated in section 5.3). Finally, the lessons learned in each arm of the "action space" progressively built up to an integrated conceptual framework of "action space" based urban land governance.

Based on the different governance patterns (government-civil society led, government-market led, and market-civil society led, different selected cases are presented in Chapters Two, Three, and Four, which are: regularisation of informal settlements, land readjustment approaches for allocating land for lowincome housing, and resettlement of informal settlers by the provision of lowincome housing respectively. The empirical evidence from the case in Chapter 4 shows that government action is pertinent in influencing the other actors' action. This has triggered the necessity to explore the role of the third actors in each arm of the "action space" concept.

In order to explore the interaction between government and civil society actors, (in Chapter 2), the notions of 'regulatory compliance' and 'regulatory noncompliance' were conceptualized. The findings were gathered at the conceptual level of legitimacy as well as at the case level of regularising of the informal settlements. Due to the lack of regulatory compliance, the "action space" was found to be skewed towards the civil society actors. This resulted in a strongly embedded social legitimacy and, therefore, in spite of the lack of legal legitimacy, the informal settlers were able to reside in the same area for a long period. Further, Chapter 2 concludes with the necessity for the intervention strategies to be developed by adding the role of market actors in a way that can narrow the gap between legal legitimacy and social legitimacy.

Aligning with the concluding remarks in Chapter 2, market actors were introduced in Chapters 3 and 4. In order to explore the "action space" between government and market actors, in Chapter 3, the notions of 'regulatory compliance' and 'regulatory noncompliance' were conceptualized. The adopted conceptual framework was applied in the case of Land Readjustment (LR). Looking through the analytical framework of "action space", it was found to be skewed towards the market sector. 
Further, to explore the "action space" between the market and civil society actors, the "action space" concept was modified in Chapter 4, by incorporating the notions of 'corporate social responsibility' (CSR) and 'social entrepreneur'. The modified conceptual framework was applied in the case of a resettlement project. Looking through this modified analytical framework of "action space", it was found to be skewed towards the civil society actors at the project level whereas, in the strategy level, it was found to be neither with the market actors nor with the civil society actors.

This chapter provides the synthesis of the findings from Chapters Two, Three and Four in accordance with the three research objectives set in Chapter 1. In this chapter, the integrated conceptual framework of "action space" is built to understand urban land governance. It is built up according to the findings and lessons learned with respect to the "action space" concept and from the three different cases.

\subsection{Main Findings from the research}

This section summarizes the main findings of each sub-objective including the research questions.

First Sub- Objective: To understand the "action space" based urban land governance patterns between government and civil society actors by developing a theoretical framework in the case of urban informal settlements and study intervention strategies for managing of informal settlements.

How can the concept of "action space" be used to develop a theoretical framework for understanding the governance patterns between government and civil society for managing informal settlements?

The theoretical framework was developed in Chapter 2 by modifying the notions of "action space" from Foxon et al. (2009). In the modified "action space" concept, the inter-relationship between government and civil society actors has been conceptualized by referring to the notions of 'regulatory compliance' and 'regulatory noncompliance'.

The result shows that there is a push and pull (dynamism) of "action space" between government and civil society (Chapter 2, section 2.7). Due to the lack of regulatory instruments in recognizing informal settlers' land rights, "action space" of the government in providing the legal legitimacy of informal settlements is lacking. However, the "action space" of local government is found to contribute to the social legitimacy of the informal settlers, by providing the utility services in informal settlements. Similarly, lack of legal norms obliged the civil society groups to pull the "action space" towards themselves. The "action space" was created in the form of various social organizations, 
especially, squatters' federations that advocate for the rights of informal settlers. In this way, civil society actors succeeded to trigger the social legitimacy for the informal settlers. Thus, the weakness in the legal norms has pushed the "action space" of local government to follow the social norms. This has blurred the boundary between the action of local government and civil society groups (Stoker, 1998).

\section{What are the intervention strategies for managing informal settlements?}

The three intervention strategies have been identified from the cases, which are i) Formulation of policy ii) Providing tenure security and iii) Land development for low-income housing. These intervention strategies focussed on minimizing the gap between legal legitimacy and social legitimacy. In addition, these intervention strategies suggest adding market actors' role in managing informal settlers ${ }^{18}$.

The first intervention is Formulation of the policy that recognizes the land rights of informal settlers. When providing land rights to informal settlers via a relocation approach, it is vital to have persuasive mechanisms in place. These persuasive mechanisms can be supplying social and physical infrastructures at affordable costs, supplying appropriate financial subsidies on housing at the relocation site, adaptation of affordable building regulations, and applying an incremental approach to upgrading. The continuum of land rights approach is found necessary to be incorporated in the land policy in order to recognize land rights of informal settlers.

The second intervention is Providing land tenure security from legal social and economic perspectives. In the case of relocation of informal settlers, an integrated approach, considering their social as well as economic needs, in finding a location for shifting the informal settlers is found to be important. Providing land and housing in the relocated site without financial obligations to repay back is not suggested as, it attracts elite groups rather than the needy groups. Therefore, a specific intervention in the land and housing market from the perspective of access to land and housing for low-income groups is required.

The third intervention is Developing land to accommodate informal settlers. The provision of low-cost land for housing and subsidies in land and housing is part of an intervention strategy to relocate existing informal settlements away from the vulnerable areas as well as to prevent the growth of informal settlements.

${ }^{18}$ In previous chapters Informal settlers are generalized as low-income groups 
Second Sub-Objective: To understand the "action space" based urban land governance patterns between government and market actors by developing a theoretical framework in allocating land for low-income housing in the case of Land Readjustment

How can the concept of "action space" be used to develop a theoretical framework for understanding the governance patterns between government and market actors in allocating land for low-income housing?

The theoretical framework is developed in Chapter 3 by modifying the notions of "action space" from Foxon et al. (2009). In the modified framework, the inter-relationship between government and market actors were conceptualized by referring to the notions of 'regulatory compliance' and 'regulatory noncompliance' that pull the "action space" towards the government actors and pull the "action space" towards the market actors respectively.

Under the 'regulatory compliance': legal norms for the participation of various government, private developers, and landowners within Land Readjustment (LR) project and inclusive legal norms for the provision of low-income plots were elaborated. Regulation like Inclusionary Housing (IH) brings market actors on board for allocating land for low-income housing. However, such regulation should be applied by incorporating some interventions that do not affect the market norms and values as reported in Chapter 3. It was found that regulatory compliance could enable the government to have access to a lowincome plot for housing low-income groups.

Similarly, under the 'regulatory noncompliance': participation of land owners and inclusveness by equitable access to land were elaborated. The regulations, which do not comply with market norms and values, do not create a level playing field between the market actors in the process of delivering land and housing for low-income groups and high-income groups. The 'level playing field' was explained within the context of 'regulatory noncompliance'. Lack of level playing field hindered on enabling of the participation of landowners and equitable access to land for private developers in the LR process to generate low-income plots.

How to incorporate market actors in the allocation of land for low-income housing?

The market actors referred in Chapter 3 are private developers in the land and housing sector and the landowners in the LR project area. The lack of level playing field among the market actors creates noncompliance with the regulations such as allocating a certain percentage of development to the lowincome groups. In order to incorporate private developers' role, it is required 
to create an outcome based level playing field in the process of delivering land for low-income groups and high-income groups. This type of level playing field facilitates in acquiring developed land for low-income housing below the market value price. To create an outcome-based level playing field in delivering land by market actors, various market interventions such as availability of land below market price, subsidies in development permit fee and betterment tax, development incentives such as exemption from property tax or flexibility in the property tax for the private developers were identified. The identified interventions could facilitate in allocating low-income plot in land development approaches like Land Readjustment.

Third Sub-objective: To understand the "action space" based urban land governance patterns between civil society and market actors by developing a theoretical framework in managing informal settlements and low-income housing in the case of resettlement of informal settlers

How can the concept of "action space" be used to develop a theoretical framework for understanding the governance patterns between civil society and market actors in managing informal settlements and low-income housing?

The theoretical framework (Chapter 4) consists of the notions to analyse the interaction between civil society and market actors in the "action space" concept by Foxon et al. (2009). The notions referred are 'corporate social responsibility' (CSR) and 'social entrepreneur' and elaborated at the strategy and project level.

The notion of CSR was conceptualized in the "action space" framework in order to bring the market actors on board in achieving social goals like the allocation of land and housing for low-income groups at strategic level and technical support in building low-income housing at the project level (see section 4.3). The results show that due to lack of CSR in the process of providing land for low-income housing, no "action space" was pushed towards private developers to provide low-income housing.

Similarly, the notion of the social entrepreneur was conceptualized to describe the civil societies' actions from the financial perspective towards social goals. The social entrepreneur in access to land for low-income housing at the strategy level and in land use planning was elaborated (see section 4.3). Findings suggest that by strengthening the financial condition of the lowincome groups, the action space was pushed towards the market that caters low-income groups. It was found that the low-income groups could cope with the market price of low-income housing due to the ability to repay the land and housing loan with money earned via social entrepreneurial activities. 
How can social and market dimensions be conceptualize considering scale and level?

The social dimension of market actors and market dimension of civil society actors can be conceptualized within the context of CSR and social entrepreneur respectively. However, these two notions need to be addressed at both the strategy level and project level. At the strategy level, the government should provide a legal framework that guides the CSR of private developers' to fulfil social goal like provision of land and housing for low-income groups. In this regard, the government needs to provide profit-oriented incentives in order to comply with the market norms. Whereas, at the project level, the private developers' technical skills such as, land surveying and low-cost building technology need to be operationalized by making those technical skills available in the process of developing low-income housing through CSR.

Similarly, the mechanism to gear social cooperatives towards social entrepreneurship need to be addressed in the land policy. In addition, the legal framework that accommodates these cooperatives in the process of delivering land and housing for low-income groups need to be developed. Besides, at the project level, land use plans are needed which can support social entrepreneurship of the settlers to enhance their economic status by creating various opportunities to start their own small business. This will then strengthen the capacity of the settlers to repay the land and housing loan by carrying out social entrepreneurial activities.

\subsection{The integrated framework of urban land governance based upon the balanced "action space"}

In this section, we present the lessons learned from the "action space" based urban land governance patterns and the lessons learned from the cases reported in Chapters Two, Three and Four. The lessons learned are synthesized in order to understand the urban land governance through "action space". In doing so, an integrated framework is developed with an attempt to balance the competing actions and logic among the three key actors. The unpacking of the generalized form of government, market and civil society actors is carried out according to the cases that were studied in Chapters (2, 3 and 4).

\section{Lessons Learned from the concept}

First Lesson: Using the generic framework of "action space" provided in Chapter 1 (Figure 1), the governance patterns between market and civil society actors were analyzed in Chapter 4. While analyzing the "action space" between market and civil society actors, the governments' role was found to be influential as well. 


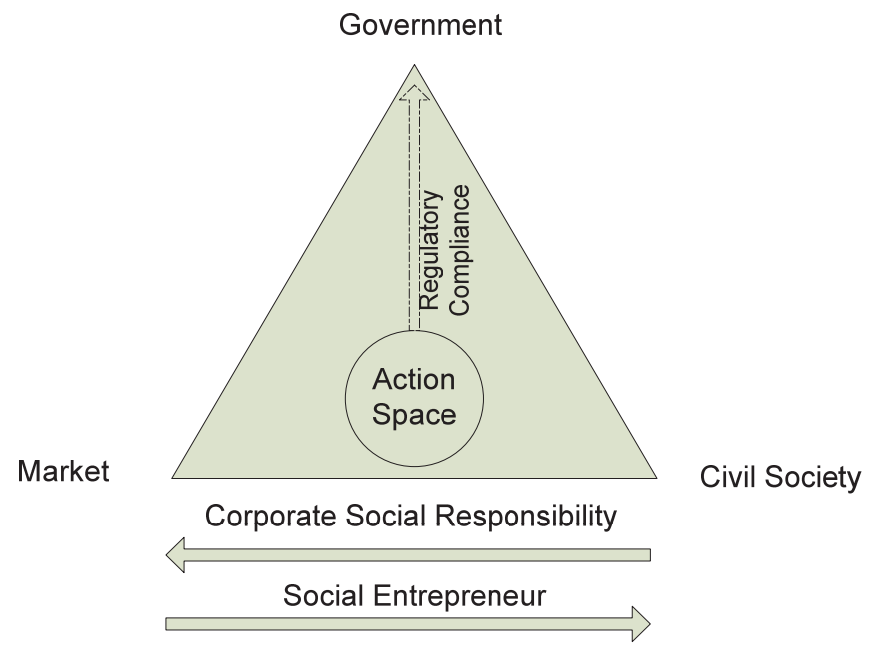

Figure 19: Government actors influence in the interaction between market and civil society

Findings suggest there is a need to divert the private actors' actions towards the social dimension via CSR at the policy level. The policy should drive the private actors into the allocation of a part of their land development to the lowincome housing. In addition to policy implications, the study reveals that CSR is necessary at the project level as well. However, to achieve the effective mobilization of private actors' action in the social context like low-income housing, a regulatory framework, which complies with the market legitimacy, is required. This shows that market actors' actions need to be regulated by government intervention in the case of land and housing for the low-income groups.

Similarly, the civil society actors' actions towards market dimension, via social entrepreneur are also needed to be addressed at the policy level as well as project level. The policies that supports social institution to conduct their social entrepreneurial activities is important for the sustainability of these institutions. Providing financial supports, tax redemption on their activities are some of the examples that support these institutions to grow. The social institutions, for instance, slum welfare cooperatives, housing and banking cooperatives, can then facilitate for the low-income groups by providing soft loans to buy land and house. In addition, such cooperatives can support in boosting social entrepreneurship of low-income people as well. At project level, social entrepreneurship via land use planning acts as a mechanism to boost the financial condition of the low-income groups by providing opportunities to conduct their own small business. This will support them to repay housing loan. 
Therefore, to bringing in the civil society actors' action in the process of delivering low-income housing via social entrepreneurship, it requires regulations that comply with the social norms and values. This reveals that the government plays a pertinent role in bringing the civil society into the process.

Second Lesson: Learning the lesson that government role is pertinent in balancing the "action space" between other two actors from Chapter 4, it triggered for looking at the role of civil society actors in balancing the "action space" between government and market actors, studied in Chapter 2.

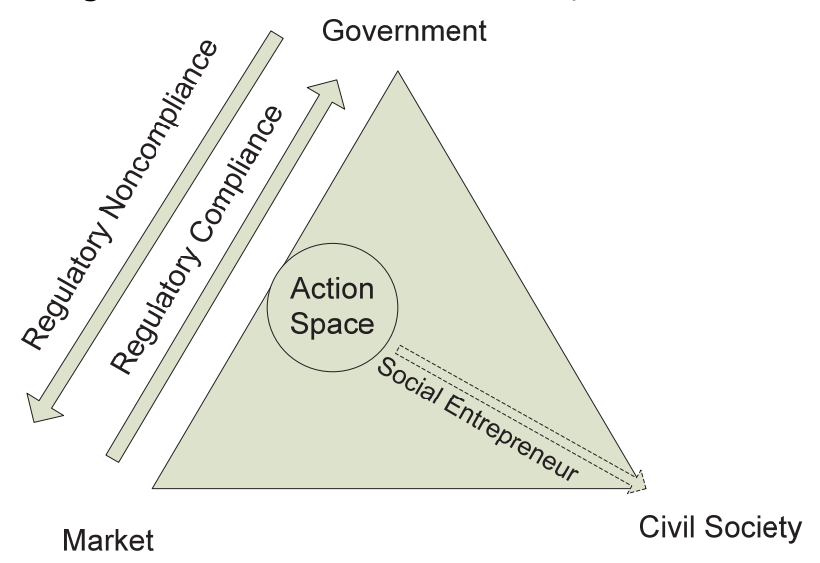

Figure 20: Civil Society actors influence in the interaction between government and market actors

Findings show that 'regulatory noncompliance' with the regulation of allocating land for low-income housing emerged due to lack of level playing field between market actors and therefore, "action space" is pulled to the market actors by catering only the high income groups. However, by developing the regulations, which comply with the market norms and values, creates level playing field for the market actors in producing land and housing below market price. Besides producing low-income housing, the beneficiaries of these housing must be able to fulfil the market norms set for these groups. This triggers for bringing in the role of civil society via social entrepreneur (conceptualized in Chapter 4) in the process of allocating low-income housing. The social entrepreneurial activities helps to boost the financial condition of low-income groups thus, enabling them to enter into the formal housing market specially created for low-income groups. In this way, a social entrepreneur can play a vital role in balancing of the "action space" between government and market actors.

Third lesson: Considering the lessons learned from the governance patterns between market- civil society and government-market, it triggered the 
balancing aspect in the government-civil society led governance pattern, studied in Chapter 2. This call for the role of market actors in balancing the "action space" between government and civil society

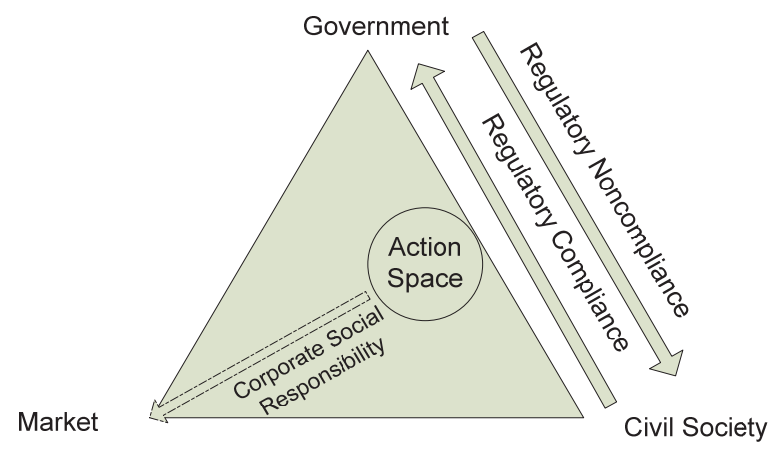

Figure 21: Market actors' influence in the interaction between Government and Civil Society actors

Chapter 2 shows that the "action space" is more towards civil society in the case of informal settlement. This is the result of the lack of regulatory compliance in addressing the land tenure issues of the informal settlers. Further, the prescribed intervention strategies in section 2.5 and concluding remarks in section 2.8, point towards bringing in the action of market actors in the process of addressing the land tenure issues of informal settlers in providing low-income housing. To bring the action of the market actors, CSR, which was conceptualized in Chapter 4, plays a vital role. It can enable the market actors in contributing to social goals like the provision of low-income housing. These actions of market actors via CSR can narrow the gap between legal legitimacy and social legitimacy by balancing the actions and logic of government and civil society actors.

\section{Lessons Learned from the cases}

Considering the homogeneity within each group of actors, they were categorized broadly, in three different groups; government, market, and civil society (Chapter 1 ). While analyzing governance patterns in each case study, the more specific categories of the actors became visible which are shown in Table 11. 
Table 11: Actors involved in the selected cases

\begin{tabular}{|c|c|c|}
\hline Government actors & Market actors & Civil society actors \\
\hline $\begin{array}{l}\text { Central Central Government: } \\
\text { Ministry of land reform and } \\
\text { management (MoLRM) }{ }^{19} \text {, } \\
\text { Ministry of urban development } \\
\text { (MoUD) } \\
\text { Ministry of federal and local } \\
\text { development (MoFALD) } \\
\text { Local Government: } \\
\text { Municipalities } \\
\text { District Development offices }\end{array}$ & $\begin{array}{l}\text { Private developers in } \\
\text { land and housing sectors } \\
\text { Landowners in Land } \\
\text { Readjustment Projects }\end{array}$ & $\begin{array}{l}\text { NGOs, INGOs } \\
\text { Federations of groups } \\
\text { from informal settlers } \\
\text { (Lumanti, SPOSH, NMES), } \\
\text { informal settlers' } \\
\text { cooperatives) }\end{array}$ \\
\hline
\end{tabular}

In the case of regularisation of informal settlements (Chapter 2), the government-civil society governance pattern has been analyzed. The identified government actors are MoLRM, MoFALD (national government) and Municipalities, District Development offices (local government (see Table 11), whereas SPOSH, NEMS and squatters cooperatives, Lumanti (INGO) are the relevant civil society groups. SPOSH-Nepal and NEMS are informal settlers' federations advocating for shelter rights and creating a social network with informal settlers residing in various districts.

Similarly, in the case of Land Readjustment (LR) (Chapter 3), the governmentmarket governance pattern has been analyzed to explore the potential of LR to deliver the low-income plots. The government actors identified in the LR process are Kathmandu Valley Authority (national government) and Kathmandu municipality (local government). The private construction companies, private developers, and landowners residing within LR project are identified as market actors.

In the third case of the resettlement project, the governance pattern between market and civil society is analyzed. The market actor involved in the KHP resettlement project was private real estate developer namely Astra Pvt Ltd. Similarly, the civil society actors involved in the project were Lumanti (NGO), squatter federations (SPOSH, NMES, federations cooperatives), Asian Coalition for Housing Rights (INGO), Slum Dwellers International (INGO), Action Aid Nepal (INGO) and Water Aid Nepal (INGO) (see Table 11).

${ }^{19}$ Ministry of land management, cooperatives and poverty alleviation 


\section{An Integrated framework of urban land Governance in managing informal settlement}

Initially, by adopting the conceptual framework of "action space" (Foxon et al., 2009), this research has attempted to analyse the dynamism in the actions of three keys actors. Since the initial conceptual framework needed modification in the specific cases, the inter-relations between each pair of actors were modified accordingly in Chapters Two, Three and Four. The cross-analysis of the findings from these chapters reflect that the logic of the third actor is equally important to balance the action space between the other two actors Furthermore, it was realised that both actions and logic of the three actors should be brought within a single conceptual framework of "action space".

Therefore, an integrated conceptual framework of "action space" (

Figure 22) is further developed. It is the developed version of the initial conceptual framework in Chapter One (section 1.6). It is based upon the lessons learned through the analysis of the governance pattern between two key actors in the Chapters Two, Three, and Four, and the cross-analysis of the findings of these Chapters. Finally, this integrated conceptual framework of "action space" presents the conceptual basis for managing the urban informal settlements from the perspective of providing housing in an affordable manner.

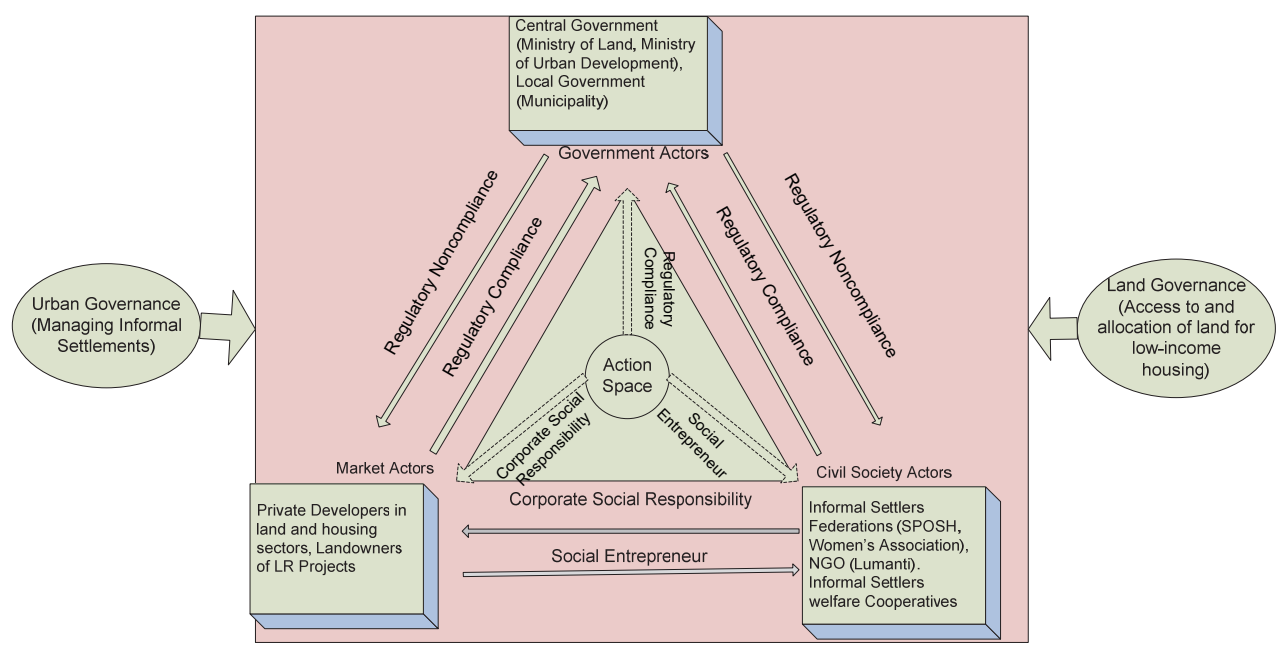

Figure 22: Integrated Framework of "action space" for understanding urban land governance

The right arm of the framework (Figure 22) has shown 'regulatory compliance' and 'regulatory noncompliance' that create the dynamism of "action space" between government and civil society. The role of market actors via corporate 
social responsibility is introduced to get the balanced "action space" between government and civil society.

Similarly, the left arm of the framework has shown 'regulatory compliance' and 'regulatory noncompliance' that create the dynamism of the "action space" between government and market. The role of civil society actors as a social entrepreneur is introduced to get the balanced "action space" between government and market.

Finally, the bottom arm of the framework has shown corporate social responsibility and social entrepreneur that create the dynamism of "action space" between civil society and market. The role of government actors via regulation which comply with norms of civil society and market actors is introduced to get the balanced action between civil society and market.

\subsection{Towards balancing "action space" for managing informal settlements}

Based upon the integrated framework of "action space" (shown in Figure 22), the balancing factors (shown in Table 12) are identified in this section as a way forward for balancing the competing logics of various actors in Nepal.

1. Market actors' role via Corporate Social Responsibility (CSR): balancing the interaction between government-civil society actors

The private land developers can allocate a certain percentage, (usually $5 \%$ to $10 \%$ ) of their developed land for building low-income housing via CSR. The private developers either can allocate land in the same project or can develop an equivalent part of the land in another place. Similarly, private developers can contribute a certain percentage of development profit to the fund such as CSF (community support fund) and the fund can be channelled to buy developed low-income plot for low-income housing.

Similarly, private actors can provide technical support via CSR in developing housing such that the price of housing is minimized. Their technical support can include surveying of ground terrain, planning, and designing of housing layout and counseling in low-cost building technology.

2. Civil society actors' role via social entrepreneur - balancing the interaction between government-market actors

The cooperatives established by informal settlers' federations (SPOSH, NMES) can be oriented towards boosting its economic status by entrepreneurial activities. These social institutions can facilitate the informal settlers by 
providing a soft financial loan in order to get access to land and housing developed for low-income groups.

In addition, the individual settlers should be able to pay the price for the land and housing that is made available for low-income groups. The entrepreneur activities such as farming, small business shops etc. need to be facilitated to boost their financial status.

3. Government actors' role via regulatory compliance - balancing the interaction between market-civil society actors

The legal framework is required to execute CSR in order to bring the private developers towards catering for low-income groups. The regulations under the CSR are required to comply with the market norms. The regulations such as easiness in receiving development permits, subsidies for permit fees and betterment tax, providing development incentives, exemptions for property tax etc are examples that satisfy market norms and can motivate the private developers in contributing towards low-income groups.

Similarly, the landowners can be facilitated by lowering their contribution of land in Land Readjustment (LR), which can lead to contribution towards social responsibility. Regulations such as Inclusionary Housing (IH), if comply with market norms such as land value capture, can convince the market actors (landowners in LR project) to set a certain percentage of developed land for low-income housing.

Likewise, the legal framework is required for enhancing the entrepreneurship of civil society actors such as SPOSH and NEMS. The cooperatives of informal settlers' federations should get legal backup for investing in profit making activities. The legal regulations that comply with social norms should be introduced to ease the actions of those social institutions towards social entrepreneurial activities. Those social institutions, which is a consortium of civil society actors, can be incorporated within the process of delivering of lowincome housing.

Moreover, the land use regulations need to facilitate social entrepreneurial activities of individual settlers. In the resettlement project, the land use can be planned by allocating space for conducting entrepreneurial activities such as cattle farming, shops, handicraft production, metal works etc. 
Table 12: Balancing Notion/factors of third actor on each arm of the "action space" framework

\begin{tabular}{|c|c|c|}
\hline $\begin{array}{l}\text { Governance } \\
\text { Pattern }\end{array}$ & Balancing Notion & Balancing factors \\
\hline $\begin{array}{l}\text { Government-civil } \\
\text { society }\end{array}$ & $\begin{array}{l}\text { Introducing the action of } \\
\text { Market actors Via Corporate } \\
\text { Social responsibility (CSR) }\end{array}$ & $\begin{array}{l}\text { Allocation of a certain percentage of } \\
\text { developed land of private } \\
\text { developers } \\
\text { Provision of technical support by } \\
\text { the private developers }\end{array}$ \\
\hline Government-Market & $\begin{array}{l}\text { Introducing the role of civil } \\
\text { society actors via social } \\
\text { entrepreneur }\end{array}$ & $\begin{array}{l}\text { The involvement of social } \\
\text { institutions } \\
\text { The involvement of the individual } \\
\text { settlers }\end{array}$ \\
\hline Civil Society-Market & $\begin{array}{l}\text { Introducing the role of } \\
\text { government actors via } \\
\text { regulatory compliance }\end{array}$ & $\begin{array}{l}\text { Introducing the policy and legal } \\
\text { framework to facilitate the market } \\
\text { actors (private developers) in CSR } \\
\text { Legal guideline to involve the } \\
\text { private developers under the CSR in } \\
\text { the technical dimension of the low- } \\
\text { income housing } \\
\text { A legal framework to incorporate } \\
\text { civil society through social } \\
\text { entrepreneurship for land use } \\
\text { Legal guideline for } \\
\text { planning at the project level that } \\
\text { enhances social entrepreneurship in } \\
\text { the individual settlers. }\end{array}$ \\
\hline
\end{tabular}

\subsection{Reflections}

\section{Main Contributions}

The main contributions of this study can be distinguished into two levels: Conceptual contribution and Societal contribution.

At a conceptual level, this study has provided a framework that could be used to understand the hybridity in the governance pattern. The proposed framework has filled the knowledge gap in the theoretical framework to analyze urban land governance based upon the various actor's actions and logic. By conceptualizing notions like corporate social responsibility, social entrepreneur, and regulatory compliance, the conceptual framework of "action space" has provided both the blended actions and logic of social and market actors in which government has a role to facilitate this mixture of actions and logic.

At a societal level, the proposed integrated framework has filled the knowledge gap regarding the practice of managing informal settlements.

$\checkmark \quad$ The integrated conceptual framework of "action space" has shown the market actors' potential in allocating land for low-income housing in Land Readjustment. 
$\checkmark \quad$ The strengthening of the civil society actors' actions by supporting the entrepreneurial activities such that the informal settlers have the capacity to repay the land and housing price.

$\checkmark \quad$ The government actions via regulations that comply with the market norms and social norms facilitates the blended action of market and civil society actors in the process of managing the informal settlements by providing low-income housing.

\section{Linking to Hybrid Governance}

Balancing within the conceptual framework of "action space" refers to the blended actions and logic among the three key actors (government, market, and civil society). This seems to be linked with the characteristic of hybrid governance as explained in publications on hybrid governance literatures (Blessing, 2012; Rhodes et al., 2014).

Hybridity in governance brings three key actors: government, market, and civil society to share part of their logic to achieve a particular goal (Blessing, 2012). In the literature based on organizational theory, hybridity is categorized as an organization that exist both in the public and private spheres (Kickert 2001). Hybridity is defined within a governance context in terms of organizations and ways of working that cut across "state, market, and civil society" (Brandsen et al, 2005a p. 6). This defines hybridity as 'the heterogeneous arrangements characterized by a mixture of actions and logic of these three key actors'. In addition, hybridity refers to the characteristics generated from the blended logics of social and market activities in which the state has a role to facilitate this mixture of actions.

Conceptually, the integrated framework of "action space" shows the hybrid action in which logic of all the three key actors are incorporated. Therefore, the integrated conceptual framework of "action space" already reflects the hybridity characteristic of urban land governance.

\section{Recommendation for future research}

This research has applied the exploratory and explanatory cases of two informal settlements to analyze the governance pattern between government and civil society and has developed the intervention strategies to fill the gap between social legitimacy and legal legitimacy. Future research should focus on applying pro-poor land tools such as STDM and the pro-poor land recordation approach in order to fill this gap and analyze how hybridity in the governance pattern can be created. 
This research has analyzed the governance pattern between government and market by applying only one type of land development approach which is Land Readjustment (LR). Besides LR, there are other land development approaches like site and service, incremental development and guided land development. Therefore, it is recommended to apply the "action space" framework to analyse governance patterns in these land development approaches and see its potential in accommodating low-income groups.

This research has analyzed the governance pattern between formal market actors and other actors (government, civil society). However, there are two types of markets: formal and informal. When the formal market fails to accommodate low-income groups then informal market tends to serve this gap. Hence, it is important to analyze governance pattern by including informal market actors as well. It is recommended for future research to apply the "action space" framework in the case of informal market that operates in the informal sectors of land and housing.

Lastly, this research has developed an integrated conceptual framework to understand the urban land governance in order to manage informal settlements. The three types of cases are studied separately by linking each arm of the "action space" framework. Therefore, further study should focus on applying this integrated conceptual framework to analyse the governance pattern among all three actors at once. 


\section{Bibliography}

Adams, D., Payne, S., \& Watkins, C. (2008). Corporate social responsibility and the UK housebuilding industry. Corporate Social Responsibility in the Construction Industry, Taylor \& Francis, London, 235-258.

Addo, I. A. (2014). Urban Low Income Housing Development in Ghana: Politics, Policy and Challenges. Urban Planning: Practices, Challenges and Benefits. New York: Nova Science Publishers.

Ahmet, Y., \& Hulya, D. (2015, May 17-21 ). Evaluation of Turkish Land Readjustment. Paper presented at the From the Wisdom of the Ages to the Challenges of the Modern World: FIG Working Week Sofia, Bulgaria.

Aiken, S. R. (1981). Squatters and Squatter Settlements in Kuala Lumpur. Geographical Review, 71(2), 158-175. doi:10.2307/214185

Alemie, B. K. (2015). Urban cadastres for urban land governance: A sociotechnical analysis: University of Twente.

Amado, M. P., Ramalhete, I., Amado, A. R., \& Freitas, J. C. (2016). Regeneration of informal areas: An integrated approach. Cities, 58, 5969.

Andrew, T. N., \& Petkov, D. (2003). The need for a systems thinking approach to the planning of rural telecommunications infrastructure. Telecommunications Policy, 27(1-2), 75-93. doi:http://dx.doi.org/10.1016/S0308-5961(02)00095-2

Appelman, M., Gorter, J., Lijesen, M., Onderstal, S., \& Venniker, R. (2003). Equal rules or equal opportunities? Demystifying level playing field, CPB Netherlands Bureau for Economic Policy Analysis, CPB Document no. 34 ,

Archer. (1992). Introducing the urban land pooling/readjustment technique into Thailand to improve urban development and land supply. Public Administration and Development, 12(2), 155-174.

Arko-Adjei, A., de Jong, J., \& Zevenbergen, J. A. (2011). Adapting land administration to the institutional framework of customary tenure : the case of peri - urban Ghana. (184), IOS Press, Amsterdam. Retrieved from http://www.itc.nl/library/papers 2011/phd/arko-adjei.pdf

Arnstein, S. R. (1969). A ladder of citizen participation. Journal of the American Institute of planners, 35(4), 216-224.

Augustinus, C. (2009). Land governance in support of the MDGs: Responding to new challenges. Paper presented at the Improving Access to Land and Shelter," World Bank and International Federation of Surveyors conference, Washington, DC, March.

Augustinus, C., Lemmen, C., \& Van Oosterom, P. (2006). Social tenure domain model requirements from the perspective of pro-poor land management. Paper presented at the Proceeding of the 5th FIG regional conference. 
Avison, D. E., \& Fitzgerald, G. (2003). Where now for development methodologies? Communications of the ACM, 46(1), 78-82.

Azzari, M., Garau, C., Nesi, P., Paolucci, M., \& Zamperlin, P. (2018). Smart City Governance Strategies to Better Move Towards a Smart Urbanism. Paper presented at the International Conference on Computational Science and Its Applications.

Badulescu, A., Badulescu, D., Saveanu, T., \& Hatos, R. (2018). The Relationship between Firm Size and Age, and Its Social Responsibility Actions-Focus on a Developing Country (Romania). Sustainability, 10(3), 805.

Bartu Candan, A., \& Kolluoğlu, B. (2015). Emerging Spaces of Neoliberalism: A Gated Town and a Public Housing Project in İstanbul. New Perspectives on Turkey, 39, 5-46. doi:10.1017/S0896634600005057

Bates, S. (2012). Bridging the governance gap: emerging strategies to integrate water and land use planning. Natural Resources Journal, 6197.

Baud, I., \& Hordijk, M. (2009). Dealing with Risks in urban Governance: What can we learn from 'resilience thinking'. Paper presented at the Conference paper, presented at the 4th international Forum on Urbanism, Amsterdam-Delft.

Bbun, T. M., \& Thornton, A. (2013). A level playing field? Improving market availability and access for small scale producers in Johannesburg, South Africa. Applied Geography, 36, 40-48.

Bjerke, B., \& Karlsson, M. (2013). Social entrepreneurship: To act as if and make a difference: Edward Elgar Publishing.

Blessing, A. (2012). Magical or monstrous? Hybridity in social housing governance. Housing Studies, 27(2), 189-207.

Boonyabancha, S., \& Mitlin, D. (2012). Urban poverty reduction: learning by doing in Asia. Environment and Urbanization, 24(2), 403-421.

Bosch, O., King, C., Herbohn, J. L., Russell, I., \& Smith, C. (2007). Getting the big picture in natural resource management-Systems thinking as 'method'for scientists, policy makers and other stakeholders. Systems Research and Behavioral Science, 24(2), 217-232.

Brunick, N. (2003). The impact of inclusionary zoning on development. Business and Professional People for the Public Interest.

Burns, T. (2007). Land Administration Reform: Indicators of Success and Future Challenges. Agriculture and Rural Development Discussion Paper 37. World Bank. Washington.

Calamia, N., \& Mauach, A. (2009). Inclusionary housing, incentives, and land value recapture. Land Lines, 21(1), 15-21.

Cash, D. W., Adger, W. N., Berkes, F., Garden, P., Lebel, L., Olsson, P., . . . Young, O. (2006). Scale and cross-scale dynamics: governance and information in a multilevel world. Ecology and society, 11(2), 8. 
Checkland, P. (2000). Soft systems methodology: a thirty year retrospective. Systems Research and Behavioral Science, 17, 11-58.

Chhetri, R. B. (2014). Land Policy Instruments in Nepal. Journal of the Institute of Engineering, 10(1), 69-79.

Chimhamhiwa, D., Molen, P. v. d., Mutanga, O., \& Rugege, D. (2009). Towards a framework for measuring end to end performance of land administration business processes - A case study. Computers, Environment and Urban Systems, 33(4), 293-301. doi:10.1016/j.compenvurbsys.2009.04.001

Czischke, D., Gruis, V., \& Mullins, D. (2012). Conceptualising social enterprise in housing organisations. Housing Studies, 27(4), 418-437.

De Kam, G. (1998). Value for money: Quality and price of land for social housing in The Netherlands. Netherlands journal of housing and the built environment, 13(4), 453-475.

De Kam, G., Groetelaers, D., \& Korthals Altes, W. (2008). Land for social housing: A framework for cross-national comparative analysis. Paper presented at the European Network for Housing Research Conference: Shrinking Cities, Sprawling Suburbs, Changing Countrysides.

De Soto, H. (2000). The mystery of capital: Why capitalism succeeds in the West and fails everywhere else: New York: Basic Books.

Deininger, K., Augustinus, C., Enemark, S., \& Munro-Faure, P. (2010a). Innovations in land rights recognition, administration, and governance. Washington,D.C.: World Bank Publications.

Deininger, K., Selod, H., \& burns, A. (2012). land governance assessment framework : identifying and monitoring good practice in the land sector : also as e-book. Washington, D.C.: The World Bank.

Deininger, K. W., Augustinus, C., \& Enemark, S. (2010b). Innovations in land rights recognition, administration, and governance: World Bank Publications.

Deng, J. S., Wang, K., Hong, Y., \& Qi, J. G. (2009). Spatio-temporal dynamics and evolution of land use change and landscape pattern in response to rapid urbanization. Landscape and Urban Planning, 92(3), 187-198. doi:https://doi.org/10.1016/j.landurbplan.2009.05.001

Dijst, M. (1999). Action space as planning concept in spatial planning. Journal of Housing and the Built Environment, 14(2), 163-182.

DUDBC, \& KVDA. (2005). Icchangu land poolig project, second phase. Detail Project Report

Duit, A., Galaz, V., Eckerberg, K., \& Ebbesson, J. (2010). Governance, complexity, and resilience. Global environmental change, 20(3), 363368.

Durand-Lasserve, A. (1999). Benefits of regularizing informal settlements. Habitat Debate, 5(3), 13-15. 
Durand-Lasserve, A. (2006). Market-driven Evictions and Displacements: Implications for the Perpetuation of Informal. Informal Settlements: $A$ Perpetual Challenge?, 207.

Durand-Lasserve, A., \& Royston, L. (2002). International trends and country contexts: From tenure regularization to tenure security. Holding their ground: Secure land tenure for the urban poor in developing countries, Earthscan, 1-34.

Earle, L. (2014). Stepping out of the Twilight? Assessing the Governance Implications of Land Titling and Regularization Programmes. International Journal of Urban and Regional Research, 38(2), 628645. doi:10.1111/1468-2427.12112

Enemark, S., McLaren, R., \& Paul, v. d. M. (2009). Land Governance in support of the Millennium Development Goals: A New Agenda for Land Professionals. Paper presented at the FIG / World Bank Conference, Washington DC.

Erdem, R., \& Meshur, M. C. (2009). Problems of land readjustment process in Turkey. Scientific Research and Essay, 4(8), 720-727.

Evrard, O., \& Goudineau, Y. (2004). Planned resettlement, unexpected migrations and cultural trauma in Laos. Development and change, 35(5), 937-962.

FAO. (2007). Good Governance in Land Tenure and Administration.

Faraj, Y. (2014). Land Strategies-Land strategies to address low-income housing in Suleimany city, Kurdistan Regional Government.

Ferguson, J. (2007). Formalities of poverty: Thinking about social assistance in neoliberal South Africa. African Studies Review, 50(02), 71-86.

Ferilli, G., Sacco, P. L., \& Blessi, G. T. (2016). Beyond the rhetoric of participation: New challenges and prospects for inclusive urban regeneration. City, Culture and Society, 7(2), 95-100.

Fernandes, E. (2011). Regularization of informal settlements in Latin America. Cambridge, MA: Lincoln Institute of Land Policy.

Foxon, T. J. (2013). Transition pathways for a UK low carbon electricity future. Energy Policy, 52, 10-24.

Foxon, T. J., Hammond, G. P., Pearson, P. J., Burgess, J., \& Hargreaves, T. (2009). Transition pathways for a UK low carbon energy system: exploring different governance patterns. Paper presented at the paper for 1st European Conference on Sustainability Transitions:'Dynamics and Governance of Transitions to Sustainability, Amsterdam, The Netherlands.

Garau, C. (2012a). Citizen participation in public planning: A literature review. International Journal of Sciences, 1(2012-12), 21-44.

Garau, C. (2012b). Focus on Citizens: Public Engagement with Online and Face-to-Face Participation-A Case Study. Future Internet, 4(2), 592606. 
Gibson, C. C., Ostrom, E., \& Ahn, T.-K. (2000). The concept of scale and the human dimensions of global change: a survey. Ecological economics, $32(2), 217-239$.

Gilbert, A. (2002). On the mystery of capital and the myths of Hernando de Soto: What difference does legal title make? International Development Planning Review, 24(1), 1-19.

Global Shelter Cluster. (2009). Global campaigns for sustainable urbanization - initial concept. Retrieved from

Gooding, T. (2016). Low-income housing provision in Mauritius: Improving social justice and place quality. Habitat International, 53, 502-516.

Gotham, K. F. (2003). Toward an understanding of the spatiality of urban poverty: the urban poor as spatial actors. International Journal of Urban and Regional Research, 27(3), 723-737.

Graham, J., Amos, B., \& Plumptre, T. (2003). Principles for good governance in the 21st century. Policy brief, 15.

Greene, M., \& Rojas, E. (2008). Incremental construction: a strategy to facilitate access to housing. Environment and Urbanization, 20(1), 89108.

Gutberlet, J., Kain, J.-H., Nyakinya, B., Ochieng, D. H., Odhiambo, N., Oloko, M., Zapata, P. (2016). Socio-environmental entrepreneurship and the provision of critical services in informal settlements. Environment and Urbanization, 28(1), 205-222.

Harpham, T., \& Boateng, K. A. (1997). Urban governance in relation to the operation of urban services in developing countries. Habitat International, 21(1), 65-77. doi:10.1016/s0197-3975(96)00046-x

Hawn, O., Chatterji, A., \& Mitchell, W. (2011). Two coins in one purse? How market legitimacy affects the financial impact of changes in social legitimacy: Addition and deletion by the Dow Jones Sustainability Index. Duke University.

Hendriks, B., Zevenbergen, J., Bennett, R., \& Antonio, D. (2019). Pro-poor land administration: Towards practical, coordinated, and scalable recording systems for all. Land Use Policy, 81, 21-38. doi:https://doi.org/10.1016/j.landusepol.2018.09.033

Holmans, A., Scanlon, K., \& Whitehead, C. M. (2002). Fiscal policy instruments to promote affordable housing.

Hong Sharon Yam, L., \& Stanley McGreal, W. (2010). House-buyers' expectations with relation to corporate social responsibility for Malaysian housing. International journal of housing markets and analysis, 3(2), 132-145.

Hong, Y.-h., \& Julia, T. (2013). Making Land Readjustment Participatory and Inclusive. Land Governance Laboratory, (Working Paper No. 1-2013). Hudson, Ohio. 
Hong, Y.-h., \& Needham, B. (2007). Analyzing land readjustment: Economics, law, and collective action: Lincoln Institute of Land Policy Cambridge, MA.

Huang, Y. (2012). Low-income housing in Chinese cities: Policies and practices. The China Quarterly, 212, 941-964.

Jack, M., \& Morris, R. (2005). The community led infrastructure finance facility (CLIFF). Article written for the International Association of Local and Regional Development Funds in Emerging markets, drawn from: http://www. citiesalliance.org/doc/resources/financing/cliff/articleIADF (FullVersionFinal)_Jun05. Pdf (Last accessed 07/06/08).

Jiboye, A. D. (2011). Sustainable Urbanization: Issues and Challenges for Effective Urban Governance in Nigeria. Journal of Sustainable Development, 4(6). doi:10.5539/jsd.v4n6p211

Johnson, R. B., \& Onwuegbuzie, A. J. (2004). Mixed methods research: A research paradigm whose time has come. Educational researcher, 33(7), 14-26.

Joshi, S. (2014). Assessment of land governance : a case of urban land readjustment. University of Twente Faculty of Geo-Information and Earth Observation (ITC), Enschede. Retrieved from http://www.itc.nl/library/papers 2014/msc/la/joshi.pdf

Kågström, M., \& Richardson, T. (2015). Space for action: How practitioners influence environmental assessment. Environmental Impact Assessment Review, 54, 110-118.

Karki, T. K. (2004). Implementation experiences of land pooling projects in Kathmandu Valley. Habitat International, 28(1), 67-88.

Kaufman, R. A. (1968). A system approach to education: Derivation and definition. Educational Technology Research and Development, 16(4), 415-425.

Keuk, J. N., Abdullah, Y. A., \& Hamdan, H. (2016). Eradicating Squatters through Resettlement Programme: A Conceptual Paper. Paper presented at the MATEC Web of Conferences.

Kigochie, P. W. (2001). Squatter rehabilitation projects that support homebased enterprises create jobs and housing: The case of Mathare $4 \mathrm{~A}$, Nairobi. Cities, 18(4), 223-233.

Klijn, E.-H. (2008). Governance and Governance Networks in Europe. Public Management Review, 10(4), 505-525. doi: $10.1080 / 14719030802263954$

Klijn, E. (2008). Governance and Governance Networks in Europe. Public Management Review, 10(4), 505-525.

Koroso, N. H., van der Molen, P., Tuladhar, A. M., \& Zevenbergen, J. A. (2013). Does the Chinese market for urban land use rights meet good governance principles? Land Use Policy, 30(1), 417-426. doi:10.1016/j.landusepol.2012.04.010 
Kötter, T., \& Friesecke, F. (2009). Developing urban indicators for managing mega cities. Land Governance in Support of the MDGs: Responding to New Challenges (Washington DC, USA).

Kumar, R. (2000). Research methodology : a step by step guide for beginners. London etc.: Sage.

Larsson, G. (1997). Land readjustment: A tool for urban development. Habitat International, 21(2), 141-152.

Lemmen, C., Oosterom, P., Uitermark, H., Thompson, R., \& Hespanha, J. (2009). Transforming the Land Administration Domain Model into an ISO standard (LADM as ISO 19152). FIG Working Week, Eilat, Israel.

Lemmen, C., Van Oosterom, P., \& Bennett, R. (2015). The land administration domain model. Land Use Policy, 49, 535-545.

Li, L.-H., \& Li, X. (2007). Land readjustment: an innovative urban experiment in China. Urban Studies, 44(1), 81-98.

Lin, T.-C. (2005). Land assembly in a fragmented land market through land readjustment. Land Use Policy, 22(2), 95-102.

Lumanti. (2005). New beginnings: Housing the urban poor. Kathmandu: Lumanti.

Mallach, A. (2010). The global reach of inclusionary housing. Affordable housing, social inclusion, and land value recapture, 323.

Mark, U. L. (2012). Managing urban land: a guide for municipal practitioners. http://www.urbanlandmark.org.za/research/x60.php

Marulanda, L., \& Steinberg, F. (1991). Land management and guided land development in Jakarta. Retrieved from Rotterdam:

Mason, S., \& Fraser, C. (1998). Image sources for informal settlement management. Photogrammetric Record, 16(92), 313-330.

Mathur, S. (2013). Use of land pooling and reconstitution for urban development: Experiences from Gujarat, India. Habitat International, 38, 199-206.

Mayntz, R. (2003). New challenges to governance theory. In H. P. Bang (Ed.), Governance as social and political communication. Oxford Road, Manchester: Manchester University

Mitlin, D. (2007). Finance for low-income housing and community development: SAGE Publications Sage UK: London, England.

Mitlin, D., \& Satterthwaite, D. (2012). Addressing poverty and inequality; new forms of urban governance in Asia: SAGE Publications Sage UK: London, England.

Mittal, J. (2014). Self-financing land and urban development via land readjustment and value capture. Habitat International, 44, 314-323.

Mittal, J., \& Swamy, H. S. (2014). Delivering Low Income Housing-Role of Access to Land and Credit in Gujarat, India. Current Urban Studies, 2(03), 233. 
Moffat, T., \& Finnis, E. (2005). Considering social and material resources: the political ecology of a peri-urban squatter community in Nepal. Habitat International, 29(3), 453-468.

Moretto, L. (2015). Application of the "Urban Governance Index" to water service provisions: Between rhetoric and reality. Habitat International, 49, 435-444. doi:https://doi.org/10.1016/j.habitatint.2015.06.004

Mukherji, A. (2014). Land Readjustment During Post-Disaster Urban Reconstruction. Journal of the American Planning Association, 80(4), 438-439.

Muñoz-Gielen, D. (2014). Urban governance, property rights, land readjustment and public value capturing. European Urban and Regional Studies, 2(1), 60-78.

Ndezi, T. (2009). The limit of community initiatives in addressing resettlement in Kurasini ward, Tanzania. Environment and Urbanization, 21(1), 7788.

Needham, B. (2007). The search for greater efficiency. Land readjustment in the Netherlands. Analyzing land readjustment-economics, law, and collective action. Cambridge, MA: Lincoln Institute of Land Policy, 115134.

Needham, B., \& de Kam, G. (2004). Understanding how land is exchanged: coordination mechanisms and transaction costs. Urban Studies, 41(10), 2061-2076.

Nepal Rastra Bank. (2011). Real Estate Financing in Nepal: A Case Study of Kathmandu Valley. Kathmandu.

Neupane, K. (2014). Public Assets Creation. Sahibato, 33, 16-22.

Nientied, P., \& Kalim, S. I. (1986). Policy constraints on planning land for lowincome groups in Karachi. Habitat International, 10(1-2), 79-92. doi:http://dx.doi.org/10.1016/0197-3975(86)90010-X

Nisha, K. C. (2015). Including Low Income Plots in Land pooling: A case of Icchangu Narayan Land Pooling Project, Kathmandu, Nepal. (Masters Master dissertation ), Erasmus University, Rotterdam, The Netherlands.

Othman, A., \& Mia, B. (2008). Corporate social responsibility for solving the housing problem for the poor in South Africa. Journal of Engineering, Design and Technology, 6(3), 237-257.

Palmer, D., Fricska, S., \& Wehrmann, B. (2009). Towards improved land governance. Retrieved from

Paris, C. (2007). International perspectives on planning and affordable housing. Housing Studies, 22(1), 1-9.

Patel, S., Baptist, C., \& d'Cruz, C. (2012). Knowledge is power-informal communities assert their right to the city through SDI and communityled enumerations. Environment and Urbanization, 24(1), 13-26. 
Patel, S., d'Cruz, C., \& Burra, S. (2002). Beyond evictions in a global city: people-managed resettlement in Mumbai. Environment and Urbanization, 14(1), 159-172.

Potoski, M., \& Prakash, A. (2005). Green clubs and voluntary governance: ISO 14001 and firms' regulatory compliance. American journal of political science, 49(2), 235-248.

Rabé, P. E. (2010). Land Sharing in Phnom Penh and Bangkok: Lessons from Four Decades of Innovative Slum Redevelopment Projects in Two Southeast Asian "Boom Towns". Paper presented at the Places We Live: Slums and urban poverty in the developing world, Washington DC.

Rahim, H. L., \& Mohtar, S. (2015). Social Entrepreneurship: A Different Perspective. International Academic Research Journal of Business and Technology, 1(1), 9-15.

Ram, P., \& Needham, B. (2016). The provision of affordable housing in India: Are commercial developers interested? Habitat International, 55, 100108.

Rhodes, M. L., \& Donnelly-Cox, G. (2014). Hybridity and social entrepreneurship in social housing in Ireland. VOLUNTAS: International Journal of Voluntary and Nonprofit Organizations, 25(6), 1630-1647.

Rhodes, R. A. W. (1996). The new governance: governing without government. Political studies, 44(4), 652-667.

Safier, M. (2003). Exploring 'Room for Manoeuvre' for 'Drivers of Change': Promoting Sustainable Progress in Urban Areas. Retrieved from http://www.ucl.ac.uk/dpuprojects/drivers urb change/interdim analysis/rationale interdim an alysis.htm\#

Sagalyn, L. (2009). Land Assembly, Land Readjustment and Public/Private Redevelopment. Land Readjustment and Public/Private Redevelopment (April 2007).

Sandhu, K. (2004). Exploring the potential of land pooling and readjustment techniques for housing poor. ITPI Journal, I.

Sanyal, B., \& Deuskar, C. (2012). A better way to grow? Town planning schemes as a hybrid land readjustment process in Ahmedabad, India. Value capture and land policies, 149, 182.

Satterthwaite, D. (2009). Getting land for housing; what strategies work for low-income groups? Environment and Urbanization, 21(2), 299-307.

Seawright, J., \& Gerring, J. (2008). Case selection techniques in case study research: A menu of qualitative and quantitative options. Political Research Quarterly, 61(2), 294-308.

Sengupta, U. (2006). Government intervention and public-private partnerships in housing delivery in Kolkata. Habitat International, $30(3), 448-461$. 
Sengupta, U., \& Sharma, S. (2009). No longer Sukumbasis: challenges in grassroots-led squatter resettlement program in Kathmandu with special reference to Kirtipur Housing Project. Habitat International, 33(1), 34-44.

Seufert, P. (2013). The FAO voluntary guidelines on the responsible governance of tenure of land, fisheries and forests. Globalizations, 10(1), 181-186.

Shrestha, P. (2010). Urban governance, planning and housing policy-shift from managerialism to entrepreneurialism. Paper presented at the N-AERUS XI Assessing and exploring the state of Urban Knowledge: Its production, Use, and Dissemination in the Cities of the South, Brussels.

Shrestha, P., \& Aranya, R. (2015a). Claiming Invited and Invented Spaces: Contingencies for Insurgent Planning Practices. International Planning Studies, 20(4), 424-443.

Shrestha, R. (2009). Assessing transparency in land acquisition for road development, case of outer ring road in Kathmandu valley. ITC, Enschede. Retrieved from http://www.itc.nl/library/papers 2009/msc/upm/Shrestha.pdf

Shrestha, R., Tuladhar, A., \& Zevenbergen, J. (2015b). Exploring land governance in post disaster: a case of informal settlement. Paper presented at the International Workshop on Role of Land Professional and SDI in Disater Risk Reduction: In the Context of Post 2015 Nepal Earthquake Kathmanu Nepal.

Shrestha, R., Tuladhar, A., Zevenbergen, J., \& Banskota, M. (2014a, June 1621 ). Decades of Struggle for Space: about the legetimacy of informal settlement in urban areas. Paper presented at the Engaging the challenges, enhancing the relevance: XXV FIG Congress Kuala Lumper, Malaysia.

Shrestha, R., Tuladhar, A., Zevenbergen, J., \& Banskota, M. (2014b). "Decades of Struggle for Space": About the Legitimacy of Informal Settlements in Urban Areas. FIG Cogress, 16-21.

Shrestha, R., Tuladhar, A., Zevenbergen, J., \& Banskota, M. (2016a). Urban Land Governance : "Action Space", Legitimacy of and Intervention Strategies for Urban Informal Settlements in Nepal Nordic Journal of Surveying and Real Estate Research, 11(2), 20-50.

Shrestha, R., Tuladhar, A. M., Zevenbergen, J. A., \& Banskota, M. (2016b). Urban Land Governance: "Action Space", Legitimacy of and Intervention Strategies for Urban Informal Settlements in Nepal. Nordic Journal of Surveying and Real Estate Research, 11(2), 20-50.

Shrestha, R., Zevenbergen, J., \& Baskota, M. (2017a). Exploring the Potential of the Land Readjustment Approach in Allocating Land for Affordable Housing from the Market Legitimacy Perspective. Paper presented at the Responsible Land Governance: Towards and Evidence Based 
Approach, Washington, DC March 20-24, 2017: Proceedings of the Annual World Bank Conference on Land and Poverty.

Shrestha, R., Zevenbergen, J., Masum, F., \& Banskota, M. (2018). "Action Space" Based Urban Land Governance Pattern: Implication in Managing Informal Settlements from the Perspective of Low-Income Housing. Sustainability, 10(7), 2202.

Shrestha, S., Amatya, I. M., Bajracharya, A., Joshi, K., Bajracharya, L., \& NishaShrestha. (2017b). Land Pooling Projects in Nepal: A Consolidated Documentation. Retrieved from Nepal:

Silverman, D. (2010). Doing qualitative research (Third edition ed.). London: Sage.

Sivam, A., \& Karuppannan, S. (2002). Role of state and market in housing delivery for low-income groups in India. Journal of Housing and the Built Environment, 17(1), 69-88.

Sorensen, A. (2000). Conflict, consensus or consent: implications of Japanese land readjustment practice for developing countries. Habitat International, 24(1), 51-73.

Squires, G. (2012). Urban and environmental economics: An introduction. New York: Routledge.

Srinivas, H. (2005). Defining squatter settlements. Global Development Research Center Web site, www. gdrc. org/uem/define-squatter. html, viewed, 9.

Stewart, J. (2012). Multiple-case study methods in governance-related research. Public Management Review, 14(1), 67-82.

Stoker, G. (1998). Governance as theory: five propositions. International social science journal, 50(155), 17-28.

Suchman, M. C. (1995). Managing legitimacy: Strategic and institutional approaches. Academy of management review, 20(3), 571-610.

Supriatna, A., \& van der Molen, P. (2014). Land readjustment for upgrading Indonesian kampung: a proposal. South East Asia Research, 22(3), 379-397.

Tanaka, M. (2009). From confrontation to collaboration: a decade in the work of the squatters' movement in Nepal. Environment and Urbanization, 21(1), 143-159.

Tang, Y., Ma, Y., Wong, C. W., \& Miao, X. (2018). Evolution of government policies on guiding corporate social responsibility in China. Sustainability, 10(3), 741.

Thomas, C. (2013). The concept of legitimacy and international law.

Tiwari, B. K. (2016). Policies and Initiatives of Kathmandu Valley Development Authority (KVDA) towards implementation of sustainable development goals Paper presented at the Workshop on the Implementation of the 2030 Agenda for Sustainable Development in Asian and Pacific cities, Bangkok, Thailand. 
Tripathi, R., \& Agarwal, S. (2013). The role of social entrepreneurs in the development of cooperatives for catalyzing empowerment in the slum areas of India. African Journal of Business Management, 7(34), 3259.

Tuladhar, A. M. (2004). Parcel - based geo - information system : concepts and guidelines. (115), ITC, Enschede. Retrieved from http://www.itc.nl/library/Papers 2004/phd/tuladhar.pdf

Turk, S. S. (2007). An analysis on the efficient applicability of the land readjustment (LR) method in Turkey. Habitat International, 31(1), 5364.

Turk, S. S. (2008). An examination for efficient applicability of the land readjustment method at the international context. Journal of Planning Literature, 22(3), 229-242.

Turk, S. S. (2014). Could Land Readjustment be Participatory and Inclusive in Turkey? Land Governance Laboratory, (Working Paper No. 6-2014). Hudson, Ohio.

Turk, S. S., \& Altes, W. K. K. (2010a). The planning system and land provision for social housing in Turkey. Housing Finance International (Online), 25(1), 26.

Turk, S. S., \& Korthals Altes, W. K. (2010b). Potential application of land readjustment method in urban renewal: Analysis for Turkey. Journal of Urban Planning and Development, 137(1), 7-19.

Turk, S. S., \& Korthals Altes, W. K. (2014). The applicability of inclusionary housing $(\mathrm{IH})$ in Turkey. Journal of Housing and the Built Environment, 29(3), 507-520. doi:10.1007/s10901-013-9358-1

Transparency International, (2004). Tools to Support Transparency in Local Governance. Transparency International, Berlin.

UN-HABITAT. (2002). The Global Campaign on Urban Governence. Retrieved from Nairobi, Kenya:

UN-Habitat (2013). Operational Policy Framework: To address the shelter needs of urban poor particularly those living in informal settlements without formal tenure. Kathmandu, Nepal.

Unger, E.-M., Zevenbergen, J., Bennett, R., \& Lemmen, C. (2019). Application of LADM for disaster prone areas and communities. Land Use Policy, 80, 118-126. doi:https://doi.org/10.1016/j.landusepol.2018.10.012

Uzun, B. (2009). Using land readjustment method as an effective urban land development tool in Turkey. Survey Review, 41(311), 57-70.

Uzun, B., Çete, M., \& Palancıoğlu, H. M. (2010). Legalizing and upgrading illegal settlements in Turkey. Habitat International, 34(2), 204-209.

Van der Krabben, E., \& Needham, B. (2008). Land readjustment for value capturing: a new planning tool for urban redevelopment. Town Planning Review, 79(6), 651-672.

Wekesa, B. W., Steyn, G. S., \& Otieno, F. A. O. (2011). A review of physical and socio-economic characteristics and intervention approaches of 
informal settlements. Habitat International, 35(2), 238-245. doi:https://doi.org/10.1016/j.habitatint.2010.09.006

Wijaya, M. B. A. (2014). Evaluation and redesign of urban governance intervention strategies to attain land tenure security for squatters : a case study in Kathmandu, Nepal. University of Twente Faculty of GeoInformation and Earth Observation (ITC), Enschede. Retrieved from https://library.itc.utwente.nl/papers_2014/msc/la/wijaya.pdf

Wilde, A. (2011). The Democratization of Governance Assessments. Retrieved from http://www.oslogovernanceforum.org/images/stories/PDFs/1.pdf

Wilson, C., Morrison, T., Everingham, J.-A., \& McCarthy, J. (2016). Steering Social Outcomes in America's Energy Heartland State and Private Meta-Governance in the Marcellus Shale, Pennsylvania. The American Review of Public Administration, 0275074016654012.

Wilson, E., \& Gran, M. G. (2007). NGOs as Market Actors: Roles and responsibilities in supporting small producers in low-income countries. Retrieved from http://pubs.iied.org/G02251/?k=NGOs+as+Market+Actors

Yap, K. S. (2016). The enabling strategy and its discontent: Low-income housing policies and practices in Asia. Habitat International, 54, Part 3, 166-172. doi:http://dx.doi.org/10.1016/j.habitatint.2015.11.026

Yau, Y. (2012). Homeowner Involvement, Land Readjustment, and Sustainable Urban Regeneration in Hong Kong. Journal of Urban Technology, 19(1), 3-22.

Yilmaz, A., Çağdaş, V., \& Demir, H. (2015). An evaluation framework for land readjustment practices. Land Use Policy, 44, 153-168.

Yin, R. K. (1994). Case study research : design and methods (Second edition ed. Vol. 5). Newbury Park etc.: Sage.

Yin, R. K. (2003). Case study research : design and methods (Third edition ed. Vol. 5). Newbury Park etc.: Sage.

Yntiso, G. (2008). Urban development and displacement in Addis Ababa: The impact of resettlement projects on low-income households. Eastern Africa Social Science Research Review, 24(2), 53-77.

Zevenbergen, J. (2002). Systems of land registration : aspects and effects : also as e-book. (51), Netherlands Geodetic Commission (NCG), Delft. Retrieved from http://www.ncg.knaw.nl/Publicaties/Geodesy/51Zevenbergen.html http://intranet.itc.nl/papers/2002/general/51Zevenbergen.pdf

Zevenbergen, J., Augustinus, C., Antonio, D., \& Bennett, R. (2013). Pro-poor land administration: Principles for recording the land rights of the underrepresented. Land Use Policy, 31, 595-604. 


\section{Summary}

Informal settlement is a worldwide issue that has existed for several decades depicting a struggle of informal settlers for the legal recognition of the occupied space. To tackle this issue, two types of approaches are being widely adopted;

i) The reactive approach, for example, in-situ upgrading and relocating in other places, and

ii) The proactive approach, for example, providing low-income housing thus, preventing illegal occupation of land for shelter purposes.

Nonetheless, various studies have shown that such settlements continue to be prevalent, particularly in the Global South; as a result of weak governance in general and urban land governance in particular.

Governance is a theoretical concept expressed in terms of "shifting patterns of responsibility" between government and non-government sectors leading to a blurring of boundaries between them. It is further articulated as integrated action within networks of key actors: Government, Market, and Civil Society. The network consist of patterns of relations between mutually dependent actors, consisting of a web of relationships between government, market and civil society actors, which interact in public policy formulation and implementation. The actors in the network are dependent on one another, as they are required to exchange resources to achieve goals. In addition, the actors in the network are autonomous actors and each have their own logic guiding their action, which are often competing. Therefore, the major challenges in governance are about bringing the competing logic of three key actors together.

The concept of governance such as water governance, environmental governance, urban governance and land governance, are brought into practice by various leading international organizations like the United Nations (UN), World Bank, FAO, UN-Habitat, GLTN and many more in various sectors. Moreover, it is realized that cross-sectoral governance is necessary for achieving global agenda like the Sustainable Development Goals (SDGs). Urban land governance, referred in this study, is a crossing-cutting of urban governance and land governance, that aims to tackle the urban governance issues of managing informal settlements by providing low-income housing, for which access to land for low-income housing is a land governance issue.

The literature on various initiatives taken by international organizations and, academic institutions regarding urban governance and land governance converges to the two types of gaps in urban land governance. These are, the Conceptual Gap; which should bring together the government, market and civil 
society actors by reconciling their conflicting actions and logic, and the Societal Gap; which should manage informal settlements in a suitable manner by adopting a proactive approach in providing access to and allocation of land for low-income housing. The concept of "action space" is adopted as an analytical framework in order to tackle the identified gaps in urban land governance. The concept of "action space" provides the potential to analyse the dynamism in the governance pattern by analysing push and pull of "action space" between each combination of actors, through the established relationship between them. In this study, the concept of "action space" is modified and conceptualized.

The general objective of this research is to understand via an "action space" based analytical framework the urban land governance in managing the informal settlements by integrating logics and actions of all three key actors (government, market, and civil society). Under the umbrella of this overarching objective, three specific objectives are studied. The first objective is to understand the "action space" between government and civil society actors in the case of urban informal settlements. The second objective is to understand the "action space" between government and market actors in allocating land for low-income housing in the case of land readjustment. And, the third objective is to understand the "action space" between civil society and market actors in managing informal settlements and low-income housing in the case of resettlement of informal settlers. The case study approach has been adopted in analyzing the governance patterns between government-civil society, government-market, and market-civil society in each sub-objective. The cases studied are: i) Regularising of informal settlements, ii) Application of a land development approach like land readjustment in allocating land for low-income housing and iii) Resettlement of informal settlers by providing low-income housing. All selected cases are from different urban areas in Nepal.

The findings from the first objective revealed that due to lack of regulatory compliance of providing legal recognition to informal settlers, the "action space" gets predominately skewed towards the civil society actors via social legitimacy and thus, enabling the informal settlers to reside in the same area for several decades. In addition, it is recommended that the gap between legal legitimacy and social legitimacy could be narrowed down by intervention strategies with a defined role for market actors. Next, findings from the second objective revealed that due to lack of regulatory compliance with market norms and values, the level playing could not be established for the market actors in the process of delivering land for low-income housing. Hence, the "action space" is skewed towards market actors, which were able to cater only for high-income groups. Lastly, the findings from the third objective revealed that the lack of policy that define market actors' role in allocating some part of their development to low-income housing via "corporate social responsibility" and 
also lack of policy to boost entrepreneurial activities of civil society groups, has resulted "action space" to be skewed neither towards market actors nor towards civil society actors. However, the "action space" was found to be skewed towards the civil society actors at the project level because of the establishment of the urban community support fund (UCSF).

The overall findings from each objective demonstrate on how each actor tries to pull or push the "action space" according to their own logic of viewing the world and the types of legitimacies (legal, social and market) that are triggered according to the action of each type of actor. Finally, the cross-analysis of the empirical evidence from the cases has given the pathway in developing the integrated analytical framework of "action space" for understanding urban land governance for managing informal settlements from the perspective of lowincome housing.

The integrated analytical framework of "action space" consists of three-core notions, which are 'regulatory compliance', 'corporate social responsibility' and 'social entrepreneur' and each notion tends to trigger the legal legitimacy, social legitimacy, and market legitimacy. The balancing of 'action space' of each pair actors is achieved by bringing in the role of the third actor into the interactions of the two other actors in the "action space". This balancing philosophy refers to the blended actions and logic among the three key actors. Finally, the understanding of the urban land governance via the integrated analytical framework of "action space" was found to be linked to the characteristics of hybrid governance.

The framework opens up a clear insight of hybridity in governance pattern. In addition, it has also filled the knowledge gap with a theoretical framework, by blending the actions and logic of various actors. As societal contribution, the findings like market actors' potential in allocating land for low-income housing via CSR and civil society actors' strength via social entrepreneur are relevant.

Based upon the overall research approach, findings and their implications, recommendations for future studies were derived. One recommendation is given to explore the applicability of the pro-poor land recordation model and STDM in creating hybridity in the governance pattern via the "action space" framework. The application of the developed framework on various other land development approaches is recommended. In addition, it is recommended to test this "action space" based analytical framework to analyse governance pattern in the case of informal land markets. Finally, the integrated framework is recommended to be tested in the case where government, market and civil society actors can be analysed all three at once. 


\section{Samenvatting}

Informele (sloppen)wijken vormen een wereldwijd probleem dat al tientallen jaren bestaat uit een strijd van informele bewoners voor de wettelijke erkenning van de door hen in bezit genomen gebieden. Om dit probleem aan te pakken, worden, op hoofdlijnen, twee benaderingen gebruikt.

i) De reactieve aanpak, bijvoorbeeld in-situ upgraden en verplaatsen naar andere gebieden, en

ii) De proactieve aanpak, bijvoorbeeld door het bieden van goedkope, betaalbare woningen, waardoor illegale inbezitname van grond voor bewoning wordt voorkomen.

Desalniettemin hebben verschillende studies aangetoond dat dergelijke informele wijken nog steeds veel voorkomen, vooral in ontwikkelingslanden; het gevolg van zwak bestuur in het algemeen en zwak stedelijk bestuur in het bijzonder.

Bestuur is een theoretisch concept dat wordt uitgedrukt in termen van "verschuivende verantwoordelijkheidspatronen" tussen overheids- en private sectoren die leiden tot vervaging van de grenzen tussen beide. Het wordt verder gekenmerkt door geïntegreerde actie binnen netwerken van de hoofdspeler: overheid, markt en burgermaatschappij. Het netwerk bestaat uit relatiepatronen tussen wederzijds afhankelijke actoren en stakeholders, bestaande uit relaties tussen overheid, private sector en civiele stakeholders, die op elkaar zijn afgestemd bij het formuleren en uitvoeren van overheidsbeleid. De actoren in het netwerk zijn afhankelijk van elkaar, omdat ze middelen moeten uitwisselen om doelen te bereiken. Verder zijn de actoren in het netwerk autonome actoren en hebben ieder hun eigen logica in hun werkwijzen, die elkaar vaak beconcurreren. Daarom zijn de belangrijkste uitdagingen inzake 'bestuur' het samenbrengen van de concurrerende logica van de drie belangrijkste actoren.

Het concept van bestuur, zoals voor waterbeheer, milieubeheer, stedelijk bestuur en landbeheer, wordt in de praktijk gebracht door verschillende toonaangevende internationale organisaties zoals de Verenigde Naties (VN), de Wereldbank, FAO, UN-Habitat, GLTN en vele andere in uiteenlopende sectoren. Bovendien wordt beseft dat sector-overschrijdend bestuur nodig is om mondiale agenda's zoals de Sustainable Development Goals (SDG's) te bereiken. Stedelijke landbeheer, waarnaar in deze studie wordt verwezen, is een combinatie van stedelijk bestuur en landbeheer, dat gericht is op het aanpakken van de stedelijke bestuurs-kwesties van het beheer van informele wijken door te voorzien in woningen voor mensen met een laag inkomen, 
waarbij het zorgen voor toegang tot grond voor woningen voor mensen met een laag inkomen een grote landbeheer uitdaging vormt.

De literatuur over verschillende initiatieven van internationale organisaties en academische instellingen met betrekking tot stedelijk bestuur en landbeheer komt overeen met de twee soorten leemtes in het beheer van stedelijk grond. Dit zijn -enerzijds- de conceptuele kloof; die de overheid, de markt en de actoren van het maatschappelijk middenveld van elkaar scheidt door hun tegenstrijdige acties en logica en -anderzijds- de maatschappelijke kloof; die op een geschikte manier een informele aanpak in de weg staat om middels een proactieve benadering te komen tot het verschaffen van toegang tot en toewijzing van grond voor woningen voor mensen met een laag inkomen. Het concept "actieruimte" is gekozen als een analytisch kader om de geïdentificeerde leemtes in het beheer van stedelijk land aan te pakken. Het concept "actieruimte" biedt de mogelijkheid om de dynamiek in het besturingspatroon te analyseren door de push en pull van "actieruimte" tussen elke combinatie van actoren te analyseren, gelet op de ontstane relatie tussen die twee. In deze studie wordt het concept van "actieruimte" gemodificeerd en geconceptualiseerd.

Het hoofddoel van dit onderzoek is om via een op "actieruimte" gebaseerd analytisch kader het stedelijk beheer van de grond te begrijpen in relatie tot informele (sloppen)wijken, en zo de logica en acties van alle drie de belangrijkste actoren (overheid, markt en burgermaatschappij) te integreren. Onder de paraplu van dit hoofddoel worden drie specifieke doelstellingen bestudeerd. De eerste doelstelling is om het op de 'actieruimte'-gebaseerde bestuurspatroon van stedelijke gebieden tussen overheid en maatschappelijke organisaties te begrijpen door een theoretisch kader te ontwikkelen in het geval van stedelijke informele wijken en interventiestrategieën te bestuderen voor het beheer van informele nederzettingen. Het tweede doel is om het op de actieruimte gebaseerde stedelijke bestuurspatroon tussen overheid en marktactoren te begrijpen door een theoretisch kader te ontwikkelen voor de toewijzing van grond voor woningen voor mensen met een laag inkomen in het geval van stedelijke herverkaveling.En de derde doelstelling is het begrijpen van het op de "actieruimte" gebaseerde patroon van stedelijk landbeheer tussen het maatschappelijk middenveld en de marktactoren door het ontwikkelen van een theoretisch kader voor het beheer van informele wijken met woningen voor mensen met een laag inkomen in het geval van verplaatsing van informele wijkbewoners. Een casestudie benadering is gehanteerd bij het analyseren van de bestuurspatronen voor elk van de subdoelstellingen tussen i) de overheid en het maatschappelijk middenveld, ii) de overheid en marktpartijen en iii) marktpartijen en het maatschappelijk middenveld. De onderzochte gevallen zijn: i) Regulering van informele (sloppen)wijken, ii) Toepassing van grondontwikkelingsinstrumenten zoals 
stedelijke herverkaveling bij de toewijzing van grond voor woningen voor mensen met een laag inkomen en iii) Verplaatsing van informele wijkbewoners middels beschikbaar stellen maken van goedkope huisvesting. Alle geselecteerde cases komen uit verschillende stedelijke gebieden in Nepal.

De bevindingen van de eerste doelstelling brachten aan het licht dat door een gebrek aan naleving van de wettelijke erkenning van informele wijkbewoners, de "actieruimte" voornamelijk via maatschappelijke legitimiteit loopt, en dus door de maatschappelijke actoren wordt gestuurd, waardoor de informele wijkbewoners al decennia lang in hetzelfde gebied kunnen verblijven. Daarnaast wordt aanbevolen om de kloof tussen wettelijke legitimiteit en sociale legitimiteit te verkleinen door interventiestrategieën met een afgebakende rol voor marktpartijen. Vervolgens lieten bevindingen uit de tweede doelstelling zien dat door een gebrek aan naleving van marktnormen en -waarden, geen eerlijk speelveld kon ontstaan voor de marktspelers in het proces van het leveren van grond voor woningen voor mensen met een laag inkomen. Vandaar dat de "actieruimte" zich niet aan de kant van de marktpartijen bevindt, die alleen in staat waren om met hoge inkomensgroepen te werken. Ten slotte lieten de bevindingen van de derde doelstelling zien dat er gebrek aan beleid is dat de rol van marktspelers definieert bij de toewijzing van een deel van de door hen te ontwikkelen woningen aan mensen met een laag inkomen via "maatschappelijk verantwoord ondernemen" en ook een gebrek aan beleid ter bevordering van ondernemersactiviteiten door het maatschappelijk middenveld. Dit heeft ertoe geleid dat de "actieruimte" zich noch aan de kant van de marktspelers noch aan de kant van het maatschappelijk middenveld bevindt. De "actieruimte" bleek zich toch meer richting de actoren van het maatschappelijk middenveld te bewegen vanwege de oprichting van het ondersteuningsfonds voor stedelijke gemeenschappen (UCSF).

De algehele bevindingen van elke doelstelling demonstreren hoe elke actor de "actieruimte" probeert te trekken of duwen volgens zijn eigen logica van het bekijken van de wereld en de vorm van legitimiteit (legaal, sociaal en markt) die wordt geactiveerd volgens de actie van elk type acteur. Ten slotte heeft de overall analyse van het empirische bewijsmateriaal uit de cases het pad aangegeven voor de ontwikkeling van het geïntegreerde analytische raamwerk van "actieruimte" voor het begrijpen van stedelijk bestuur voor het beheren van informele (sloppen)wijken vanuit het perspectief van woningen voor mensen met een laag inkomen.

Het geïntegreerde analytische raamwerk van 'actieruimte' bestaat uit driekernbegrippen, 'naleving van regelgeving', 'maatschappelijk verantwoord ondernemen' en 'sociaal ondernemerschap' en elk begrip heeft de neiging om de wettelijke legitimiteit, de sociale legitimiteit of de legitimiteit van de markt 
mogelijke te maken. Het balanceren van de 'actieruimte' tussen elk paar actoren wordt bereikt door de rol van de derde actor in te brengen in de interacties van de twee andere actoren in de 'actieruimte'. Deze evenwichtsfilosofie verwijst naar de gecombineerde acties en logica van de drie belangrijkste actoren. Ten slotte bleek het begrip van het stedelijk grondbestuur via het geïntegreerde analytische raamwerk van "actieruimte" nauw verwant aan de kenmerken van hybride governance.

Het raamwerk opent een duidelijk inzicht in hybriditeit in het governancepatroon. Daarnaast heeft het ook de kenniskloof gevuld met een theoretisch kader, door de acties en logica van verschillende actoren te vermengen. Als maatschappelijke bijdrage zijn de bevindingen, zoals het potentieel van marktspelers bij het toewijzen van grond voor woningen voor mensen met een laag inkomen via maatschappelijk verantwoord ondernemen en de kracht van maatschappelijke organisaties, via sociaal ondernemerschap relevant.

Op grond van de algemene onderzoeksaanpak, bevindingen en hun implicaties, wordt vervolgonderzoek aanbevolen, waaronder een aanbeveling om de toepasbaarheid van het model voor goedkope lokale grondboekhoudingen en het STDM te onderzoeken in het creëren van hybriditeit in het governancepatroon via het "actieruimte"-raamwerk.

Ook de toepassing van het ontwikkelde raamwerk op verschillende andere grondontwikkelingsinstrumenten wordt aanbevolen. Daarnaast wordt aanbevolen om dit op "actieruimte" gebaseerde analyseraamwerk te testen om het governance-patroon te analyseren in het geval van informele grondmarkten. Ten slotte wordt aanbevolen om het geïntegreerde raamwerk te testen in het geval dat overheids-, markt- en maatschappelijke actoren alle drie tegelijkertijd kunnen worden geanalyseerd. 


\section{Annex 1:}

Annex Table 1: Perceptions of landowners (20) residing near low-income housing concerning participation

\begin{tabular}{|c|c|c|}
\hline Factors & Landowners' view & Remarks \\
\hline $\begin{array}{l}\text { Informed about the } \\
\text { purpose of the } \\
\text { constructed building } \\
\text { near the vicinity }\end{array}$ & $\begin{array}{l}\text { Heard about it (No: } 2 \\
\text { Yes: } 18 \text { ) }\end{array}$ & $\begin{array}{l}\text { Most of the settlers } \\
\text { have the idea that the } \\
\text { house has been } \\
\text { constructed targeting } \\
\text { low-income groups }\end{array}$ \\
\hline $\begin{array}{l}\text { Informed about the } \\
\text { beneficiaries in the } \\
\text { housing }\end{array}$ & $\begin{array}{l}\text { Know about the } \\
\text { beneficiaries of the } \\
\text { housing ( } 4 \text { : less clearly; } \\
13 \text { not clearly; } 3 \text { not at } \\
\text { all) }\end{array}$ & $\begin{array}{l}\text { In the rank scale of } \\
\text { (very clearly, clearly, } \\
\text { less clearly, not clearly, } \\
\text { not at all ) }\end{array}$ \\
\hline $\begin{array}{l}\text { Effects on land value due } \\
\text { to low-income housing/ } \\
\text { people }\end{array}$ & $\begin{array}{l}\text { Very much (12); Much } \\
\text { (5); Not much (3) }\end{array}$ & $\begin{array}{l}\text { In the rank scale of } \\
\text { (very much, much, not } \\
\text { much, not at all) }\end{array}$ \\
\hline
\end{tabular}

This data is derived from survey interview with the landowners residing near lowincome housing

\section{Annex 2:}

Annex Table 2: Land development for housing in Kathmandu Valley (up to 2014)

\begin{tabular}{|c|c|c|c|c|c|}
\hline Approaches & $\begin{array}{l}\text { Area } \\
\text { (Hectares) }\end{array}$ & $\begin{array}{l}\text { Development } \\
\text { Agency }\end{array}$ & $\begin{array}{l}\text { Inclusionary } \\
\text { Zoning criteria }\end{array}$ & Implementation & Remarks \\
\hline $\begin{array}{l}\text { Sites and } \\
\text { Services }\end{array}$ & 37.34 & KVTDC & $\begin{array}{l}\text { Minimum } 10 \% \\
\text { of housing plots }\end{array}$ & $\begin{array}{l}\text { Mostly targeted } \\
\text { to government } \\
\text { officials }\end{array}$ & \multirow{7}{*}{$\begin{array}{l}\text { Housing for poor } \\
\text { mentioned in } \\
\text { urban policy } 2007 \\
\text { and Shelter policy } \\
2012 \text {, Town } \\
\text { Development } \\
\text { Directives (TDD) } \\
\text { No clear criteria } \\
\text { to define } \\
\text { beneficiaries of } \\
\text { low income } \\
\text { groups }\end{array}$} \\
\hline $\begin{array}{l}\text { Guided Land } \\
\text { Development } \\
\text { (GLD) }\end{array}$ & $\begin{array}{l}\text { Access } \\
\text { road of } \\
324 \mathrm{~km}\end{array}$ & KVTDC & & & \\
\hline $\begin{array}{l}\text { Land Pooling/ } \\
\text { Land } \\
\text { Readjustment }\end{array}$ & 259 & $\begin{array}{l}\text { KVTDC, } \\
\text { KVDA, TDC, } \\
\text { TDIC, KMC, } \\
\text { Municipality }\end{array}$ & $\begin{array}{l}\text { Up to } 10 \% \text { of } \\
\text { reserve plots }\end{array}$ & $\begin{array}{l}\text { None of the } \\
\text { land pooling } \\
\text { project has } \\
\text { addressed these } \\
\text { norms except in } \\
\text { the Icchangu } \\
\text { project) }\end{array}$ & \\
\hline $\begin{array}{l}\text { Land } \\
\text { Development } \\
\text { Developers }\end{array}$ & 68 & $\begin{array}{l}\text { Private } \\
\text { Developers }\end{array}$ & $\begin{array}{l}10 \% \text { of } \\
\text { developed plot }\end{array}$ & $\begin{array}{l}\text { not } \\
\text { implemented }\end{array}$ & \\
\hline $\begin{array}{l}\text { Housing } \\
\text { Developers }\end{array}$ & 59 & & $\begin{array}{l}10 \% \text { of housing } \\
\text { floor area }\end{array}$ & $\begin{array}{l}\text { not } \\
\text { implemented }\end{array}$ & \\
\hline $\begin{array}{l}\text { Apartment } \\
\text { Developers }\end{array}$ & 100 & & & & \\
\hline $\begin{array}{l}\text { Land } \\
\text { Developers }\end{array}$ & \multicolumn{4}{|c|}{ Informal developers major supplier of developed land } & \\
\hline
\end{tabular}

This data is derived from (Neupane, 2014; Nisha, 2015) and authors field visit during 2015 and 2016 


\section{Author's Biography}

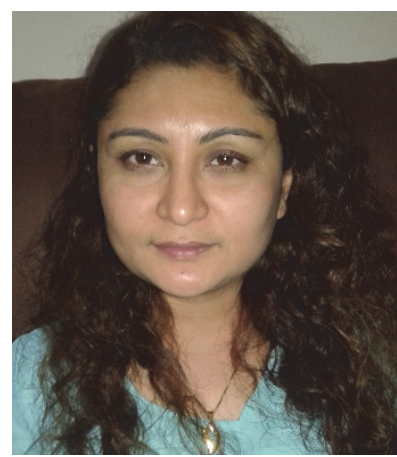

I obtained my Intermediate degree in 1996 in Electronics Engineering and a Bachelor degree in Civil Engineering in 2002 from Tribhuwan University, Nepal. In 2007, I received a grant from Netherlands Fellowship Program (NFP) to pursue Master of Science and Earth Observation: specialization in Urban Planning and Management in the University of Twente, Faculty of Geo-information Science and Earth Observation (ITC). Before perusing my MSc, I was employed in the Civil engineering firm and Geoinformation service provider firm. After completion of MSc, I am associated with Kathmandu University (KU) initially as a Lecturer and then Assistant Professor. During my Ph.D. period, I was continuously involved in the research activities in the Land Administration Program at the Department of Civil and Geomatics Engineering. My experience during the period of 16 years in the professional as well as an academic field is much diversified. In the professional field, the experience is gathered from core technical knowledge in software development up to the use of software such as GIS and RS in combatting the real field problem. Whereas, in the academic field, the learning curve is diverted from core technical domain towards a more broad platform of management and finally higher knowledge in the field of policy level and governance.

\section{List of Publications}

Shrestha, R., Tuladhar, A., Zevenbergen, J., \& Banskota, M. (2014). Decades of Struggle for Space: about the legetimacy of informal settlement in urban areas. Paper presented at the In: Engaging the challenges, enhancing the relevance: proceedings of XXV FIG Congress,16-21 June 2014, Kuala Lumper, Malaysia.

Shrestha, R., Tuladhar, A., \& Zevenbergen, J. (2015). Exploring land governance in post disaster: a case of informal settlement. Paper presented at the International Workshop on Role of Land Professional and SDI in Disater Risk Reduction: In the Context of Post 2015 Nepal Earthquake, $25^{\text {th }}-27^{\text {th }}$ November,2015, Kathmanu Nepal.

Shrestha, R., Tuladhar, A. M., Zevenbergen, J. A., \& Banskota, M. (2016). Urban Land Governance: "Action Space", Legitimacy of and Intervention Strategies for Urban Informal Settlements in Nepal. Nordic Journal of Surveying and Real Estate Research, 11(2), 20-50. 
Shrestha, R., Zevenbergen, J., \& Baskota, M. (2017). Exploring the Potential of the Land Readjustment Approach in Allocating Land for Affordable Housing from the Market Legitimacy Perspective. Paper presented at the Responsible Land Governance: Towards and Evidence Based Approach, Proceedings of the Annual World Bank Conference on Land and Poverty, 20-24, March 2017, Washington DC, United States.

Shrestha, R., Zevenbergen, J., Masum, F., \& Banskota, M. (2018). "Action Space" Based Urban Land Governance Pattern: Implication in Managing Informal Settlements from the Perspective of Low-Income Housing. Sustainability (2071-1050), 10(7).

Shrestha, R., Zevenbergen, J., Banskota, M., \& Masum, F. (2019). "Action space" in Land Readjustment: Urban Land Governance, Low-Income Housing Issues of Informal Settlers in Nepal. (Submitted to Land). 